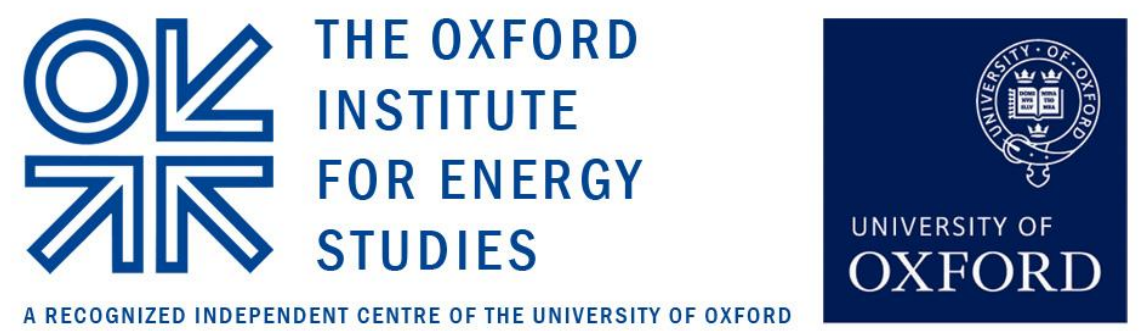

\title{
The Evolution and Functioning of the Traded Gas Market in Britain
}

\author{
Patrick Heather
}

NG 44

August 2010 
The contents of this paper are the authors' sole responsibility. They do not necessarily represent the views of the Oxford Institute for Energy Studies or any of its members.

Copyright $@ 2010$

\section{Oxford Institute for Energy Studies}

(Registered Charity, No. 286084)

This publication may be reproduced in part for educational or non-profit purposes without special permission from the copyright holder, provided acknowledgment of the source is made. No use of this publication may be made for resale or for any other commercial purpose whatsoever without prior permission in writing from the Oxford Institute for Energy Studies.

ISBN

978-1-907555-15-2 


\section{Preface}

Trading has revolutionised the commercial operation of the British gas market since the mid-1990s, and promises to have a similar impact in Continental Europe in the 2010s. Yet it is very difficult for those outside the industry to understand exactly how gas trading evolved and how it operates. Patrick Heather's long experience of trading energy commodities, and the fact that he worked as a gas trader from the start of these activities in the UK, make him an ideal author of this study. Patrick was one of the Gas Programme's first research fellows and we have benefitted a great deal from his experience of the commercial side of UK and European gas markets. I am very grateful to him for seeing this paper through to publication. It is a valuable contribution to the gas literature in a very under-researched area of the subject.

Jonathan Stern, Oxford 


\section{Contents}

1. Introduction ..........................................................................................................................1

2. Historical background .........................................................................................................................

2.1 The Power of Privatisation ....................................................................................................... 1

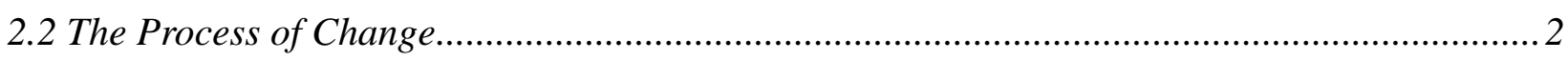

2.3 British, Americans and Continental Europeans! .................................................................... 4

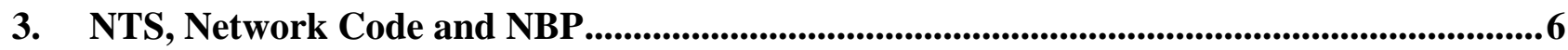

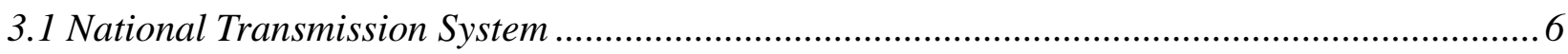

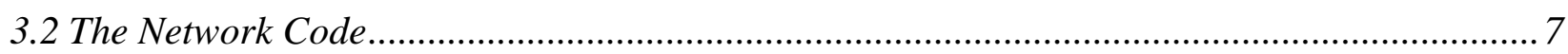

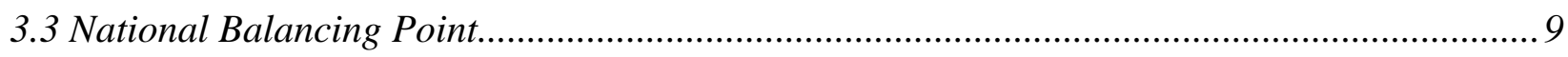

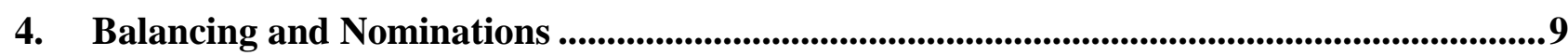

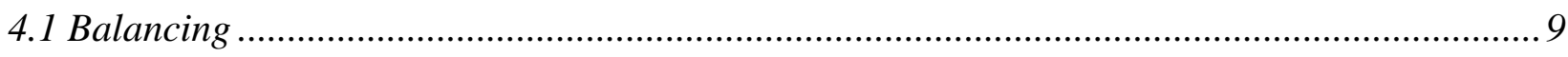

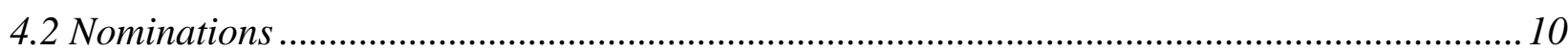

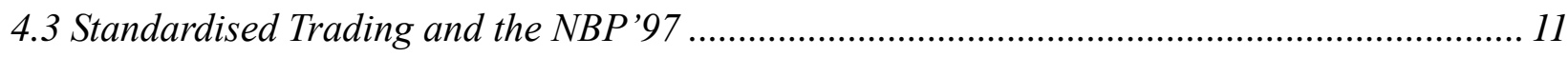

5. The Functioning of Today's Traded Market.......................................................................12

5.1 Natural Gas - the Physical Commodity ............................................................................ 12

5.2 Natural Gas - the Traded Commodity ............................................................................ 19

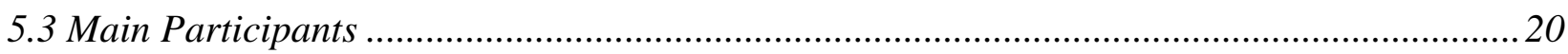

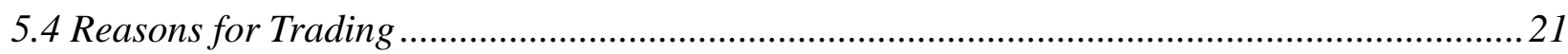

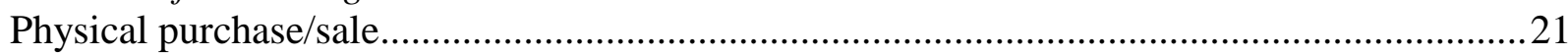

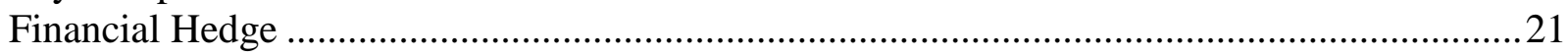

Example of how a company can protect its profit margin through hedging:..........................22

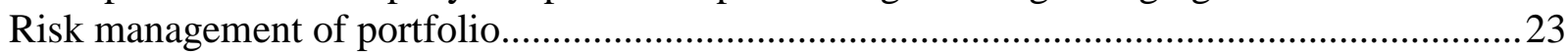

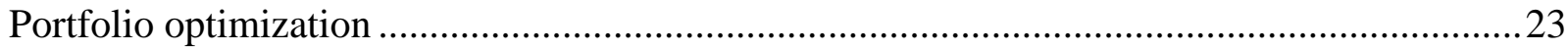

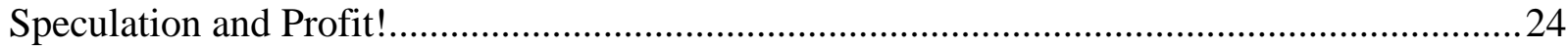

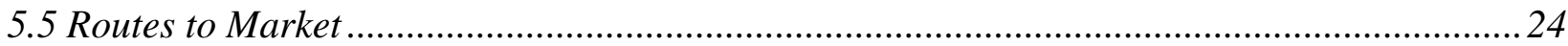

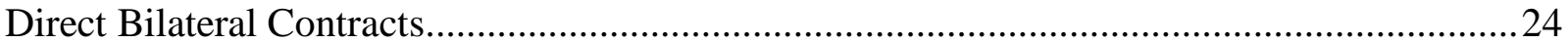

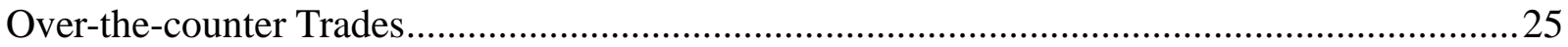

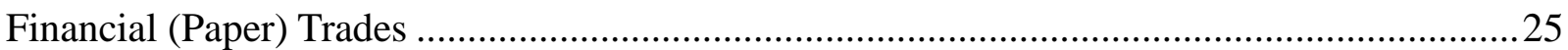

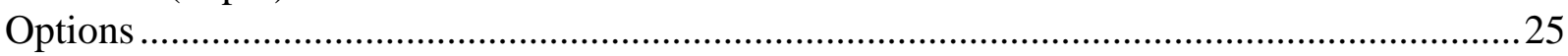

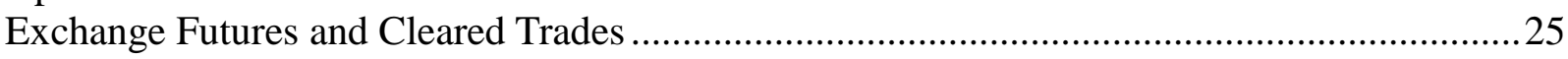

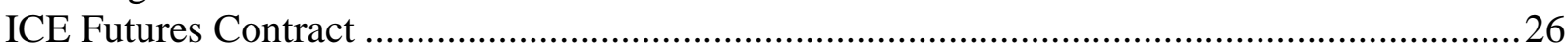

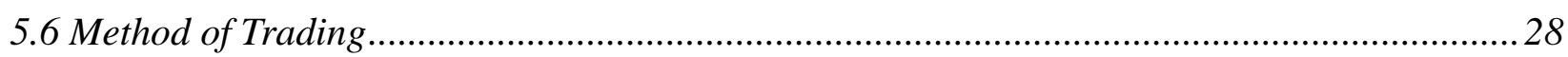

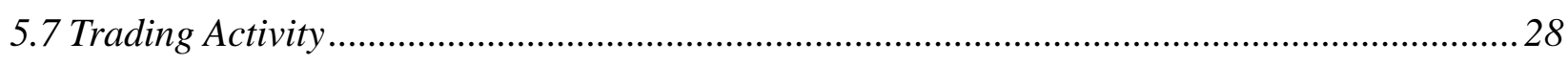

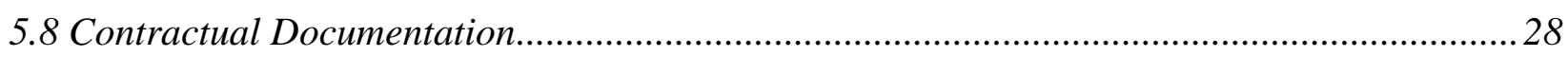

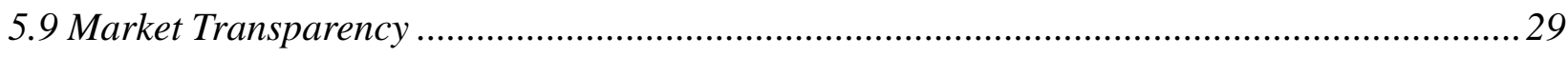




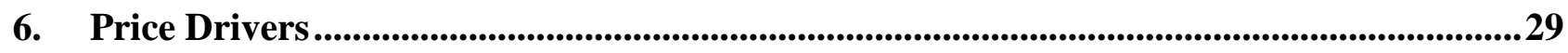

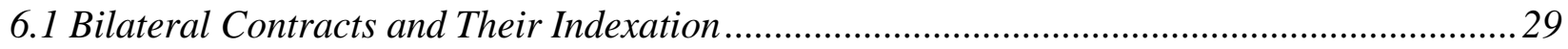

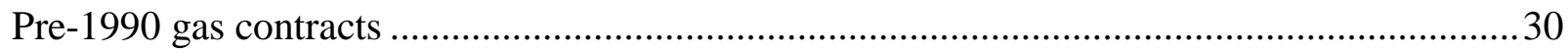

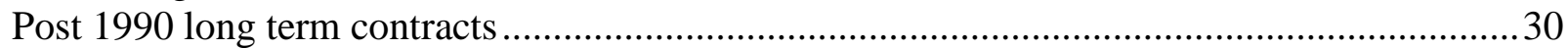

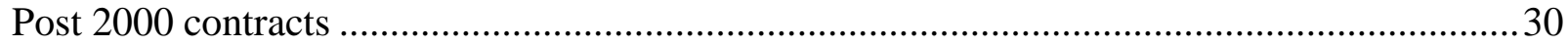

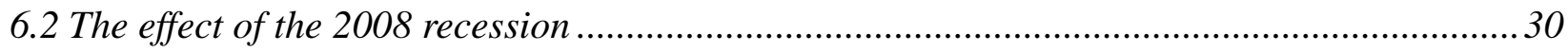

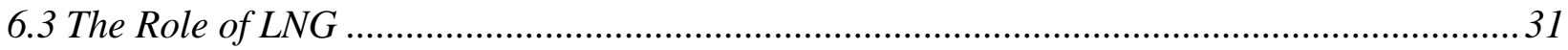

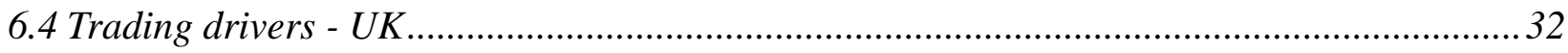

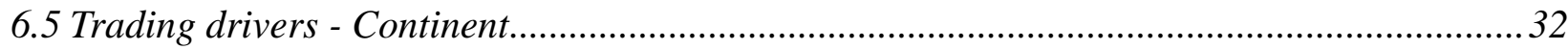

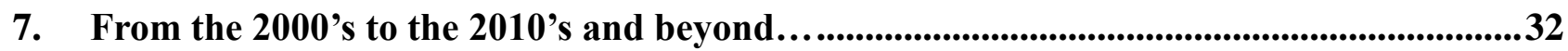

7.1 Commercial prospects for the UK gas market .......................................................................32

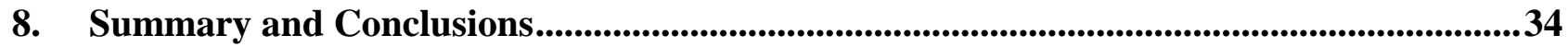

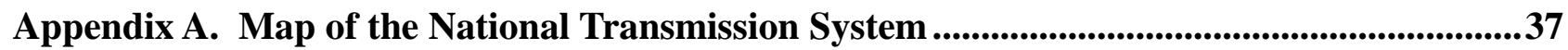

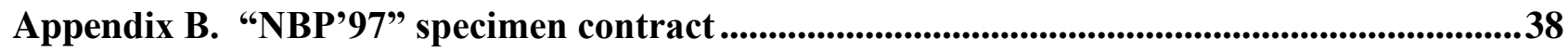

Appendix C. Conversion values .............................................................................................................48

Appendix D. ICE UK NBP Natural Gas Futures Contract specification ......................................50

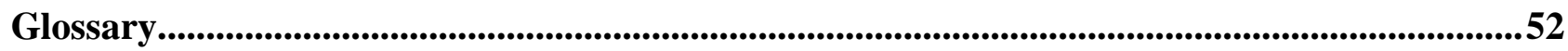

Tables

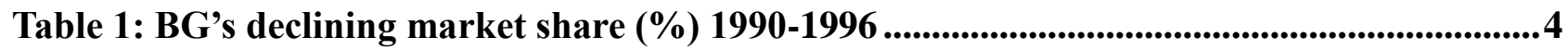

Table 2: Fuel used in electricity generation: selected years 1998 - 2008 ....................................... 14

Table 3: Power stations which have 'opted out' of the LCPD...............................................15

Table 4: UK import infrastructure as of Q1 2010 - existing and under construction ...............17

Table 5: UK import infrastructure: proposed ........................................................................................18

Table 6: Traded and physical volumes at European hubs.............................................................19

Table 7: Main UK-based participants in the British gas market............................................20

Table 8: European participants in the NBP and the brokers ...............................................................21

Table 9: Hedging: 3 example scenarios and $p+1$ accounts ...........................................................23

Table 10: Extract from ICE website $24^{\text {th }}$ March, 2010 ......................................................27 


\section{Figures}

Figure 1: Components of primary energy in $2009(\%)$.................................................................13

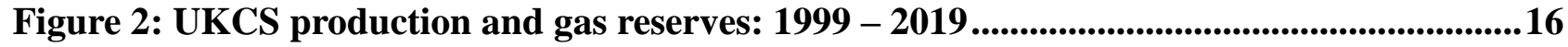

Figure 5: Contractual relationship when trading futures contracts ............................................26

Figure 6: ICE Natural gas index October 2008-April 2010 ............................................................27

Figure 7: Liquefaction and regasification capacity - existing, under construction and planned 31

Figure 8: European gas hubs price comparison, Jan 2008-May 2010 ....................................34 


\section{Introduction}

In this paper, we examine the evolution and functioning of the traded gas market in Great Britain. ${ }^{1}$ We will begin by looking at the historical background and the reasons why a successful liberalised gas market was able to develop in Britain. We will look at the Network Code and the National Balancing Point and examine their importance in facilitating an efficient wholesale market, effective balancing and nominations, before turning our attention to how the traded market actually functions. We will examine natural gas as a physical and as a traded commodity, analyse the market structure, (supply, demand and liquidity), explain the different routes to market, and the contractual documentation needed to trade. We will review the price drivers in the British market, looking at the three main phases of the bilateral contracts, contract indexation and the role of LNG and other commodities in natural gas pricing, culminating in a review of the trading dynamics in Britain and in Europe. Finally, we will examine the commercial prospects for the British gas market as it transitions from the 2000s to the 2010s and beyond in a changing global gas environment.

\section{Historical background}

It is important to understand the unique nature of Britain's liberalised natural gas market. Its structure is very different to that of any other liberalised gas market in the world, including the North American markets, (which have been liberalised for much longer), or Continental European markets, which have arguably not yet attained full liberalisation. In the UK the process of change was initiated by Prime Minister Thatcher's programme of privatisation of nationalised industries, rather than by a desire for liberalisation per se.

\subsection{The Power of Privatisation}

When the Conservatives came to power in 1979, the UK economy was in a weakened state as a consequence of stagflation (a phenomenon in which inflation and unemployment steadily increase). This situation had been building up throughout the decade, following on from the oil price shocks of the 1970s and the worsening economic performance, partially as a consequence of ongoing poor labour relations, ending with the 1978/79 "Winter of Discontent". 2,3,4 The country had a loan facility from the IMF and the funding and future investment of the then nationalised industrial sectors continued to burden government finances. ${ }^{5}$ Margaret Thatcher's government realised that privatising the nationalised industries would generate income whilst at the same time requiring the newly-formed private companies to fund future investment.

\footnotetext{
${ }^{1}$ This paper deals with the natural gas situation in Great Britain - England, Scotland and Wales - and not the UK (including Northern Ireland).

2 'Energy, the State and the Market', Dieter Helm, OUP 2003, pages 68-71:'The seeds of conflict in the 1970's"

3 'A History of Modern Britain', Andrew Marr, Macmillan 2007, Pages 366 - 377

${ }^{4}$ The two following links from BBC News will help set the scene: http://news.bbc.co.uk/onthisday/hi/dates/stories/january/22/newsid_2506000/2506715.stm http://news.bbc.co.uk/onthisday/hi/dates/stories/january/10/newsid_2518000/2518957.stm 5 The National Archives - Cabinet Papers "Sterling devalued and the IMF loan" link: http://www.nationalarchives.gov.uk/cabinetpapers/themes/sterling-devalued-imf-loan.htm
} 
This was a very different initial objective to the Brussels goal of liberalising European energy markets for the sake of competition. ${ }^{6}$

The British privatisation process, once initiated, could be justified in the context of the government's desire for free markets and controlled by introducing new regulation to ensure both fairness and competition. The British situation was very much a political move, enforced through legislation, but based on the strengths of the City of London, which has in the view of most commentators made liberalisation an unqualified success in Britain. However, there are some who argue that the whole process was an unmitigated disaster! $!^{7}$

\subsection{The Process of Change}

We will now look at how the industry moved from the "old world" public utility, through a period of change to the "new world" of privatised companies operating in a fully liberalised market. The "old world' consisted of the British Gas Corporation (BGC), which was an amalgamation of the Gas Council and twelve Area Gas Boards. The BGC was a de facto monopsony, ${ }^{8}$ buying virtually all gas produced in and around Britain and having a statutory monopoly to supply gas to end users for fuel use. Under this regime, reliable balancing (the matching of input and output volumes) was obtained primarily by the flexibility accorded to it in BGC's long term purchase contracts, which was possible because of the proximity of the fields to market, but also by the use of storage and interruptible supply contracts.

The upstream price of gas was highly variable and complex, as each contract had its prices and terms individually negotiated sometimes over many months before reaching agreement. The negotiations were often influenced by government policy, which in itself had a tendency to change every few years. Downstream pricing was based on the weighted average cost of gas (WACOG), plus a margin to cover transportation and distribution costs plus profit.

We shall look at the main phases of bilateral gas contracts in more detail in the final section of this paper. $^{9}$

The process of change was instigated by Margaret Thatcher's Conservative government during her first term of office. In 1982 the first of many important Acts of Parliament was passed to allow the industry to transform from one public utility to several privatised companies operating in a liberalised environment. In the Oil \& Gas (Enterprise) Act of 1982, ${ }^{10}$ BGC's statutory right of first refusal on purchases of gas from offshore or onshore gas producers was removed, thereby allowing third party access for the first time, although in reality it would have been extremely difficult for anyone other than BGC to purchase, transport and onward sell any gas.

\footnotetext{
${ }^{6}$ One of the early EC pro-competition directives, concerning the common rules for the internal market in natural gas was Directive 98/30/EC dated $21^{\text {st }}$ July 1997 which can be accessed at: http://eur-lex.europa.eu/LexUriServ/LexUriServ.do?uri=CELEX:31998L0030:EN:HTML More information on the EC gas regulatory forum, the Madrid Forum can be found at: http://ec.europa.eu/energy/gas_electricity/forum_gas_madrid_en.htm

7 'Gas Price Formation in the UK: Markets and Insecurity of Supply', Philip Wright, OUP, 2006

${ }^{8}$ Monopsony is a situation in which there is only one customer for a product. Sometimes called a buyer's monopoly.

${ }^{9}$ See "Bilateral contracts and their indexation" p29

${ }^{10}$ The full Oil and Gas (Enterprise) Act 1982 (c23) can be accessed at:

http://www.statutelaw.gov.uk/legResults.aspx?LegType=All+Legislation \&title=oil+and+gas+enterprise+act+1982\&sea rchEnacted=0 \& extentMatchOnly $=0$ \& confersPower $=0$ \&blanketAmendment $=0$ \& TYPE $=Q S \&$ NavFrom $=0 \&$ activeText DocId=1332487\&PageNumber=1\&SortAlpha=0
} 
The first major change facilitating genuine competition came with the Gas Act $(1986) ;{ }^{11}$ this Act was key to the process of gas liberalisation in Britain as it sanctioned the privatisation of BGC and the subsequent formation of British Gas PLC (BG). It removed BG's monopoly to supply very large customers, using more than 25,000 therms $(732,678 \mathrm{kWh})$ per annum, whilst obliging it to transport competitors' gas through its own pipelines. This Act also established the first gas regulator - the Office of Gas Supply (OFGAS).

It is important to stress however that under this initial framework competition was very slow to develop. This was merely the first step in a ten year process. In 1988, the Monopolies and Mergers Commission (MMC) recommended ${ }^{12}$ that, following their inquiry, BG should be allowed to contract no more than 90 $\%$ of any "new" gas brought to market and that BG should publish price tariffs for the Industrial and Commercial market.

The government believed that the initial measures to transform the British gas market were a political success and this encouraged it to pass the Electricity $\mathrm{Act}^{13}$ in 1989, which created the framework for the power sector privatisation, which was followed a year later by the start of trading in the Electricity Pool (England and Wales).

In 1990, British Gas, in the first of many corporate restructures, created three main divisions: the UK Gas Business; Global Gas and Exploration and Production. At this stage the three divisions existed within British Gas. Despite these significant changes since BG PLC was formed, the company again came under scrutiny in the 1991 Office of Fair Trading review. ${ }^{14}$ The OFT found that insufficient competition had developed and doubted that, given the structure of the market this situation would change significantly in the future. Following this review, BG undertook to reduce its market share and to release some of its gas by selling it to other suppliers. In 1992 its consumer threshold was reduced to 2,500 therms $(73,268 \mathrm{kWh})$ per annum. Only a year later the Monopolies and Mergers Commission took yet another look at how BG was operating, ${ }^{15}$ and this time recommended that the company be required to separate or "unbundle" its three main divisions into separate subsidiaries. This BG did a year later in 1994, including the creation of Transco, which was responsible for transport and storage.

Possibly the most important Act of Parliament passed to allow the creation of a fully liberalised gas market was the Gas Act (1995). ${ }^{16}$ This paved the way for competition in the residential market, something which had not been envisaged in the original privatisation act. This Act set out in law a timetable for full competition in the British gas market. It established a new licensing system defining pipeline operators (Gas Transporters), wholesalers (Gas Shippers) and retailers (Gas Suppliers) The result of legislation and regulation was that British Gas 'lost' a significant proportion of its market share to independent suppliers. The extent to which British Gas lost market share can be seen in Table $1 .{ }^{17}$

\footnotetext{
${ }^{11}$ The full Gas Act 1986 (c44) can be accessed at:

http://www.statutelaw.gov.uk/legResults.aspx?LegType=All+Primary \&PageNumber=38\&NavFrom=2\&activeTextDoc $\mathrm{Id}=\mathbf{2 3 4 3 6 1 8}$

${ }^{12}$ Monopolies \& Mergers Commission (1988), "Gas - a report into the existence or possible existence of a monopoly situation in relation to the supply in Great Britain of gas through pipes to persons other than tariff customers", London, HMSO, CM500 can be accessed at:

http://www.competition-commission.org.uk/rep_pub/reports/1988/232gas.htm\#full

${ }^{13}$ The full Electricity Act 1989 (c29) can be accessed at: http://www.opsi.gov.uk/acts/acts1989/ukpga_19890029_en_1

${ }^{14}$ A description can be found in the 1993 Office of Fair Trading (OFT) review, (paragraphs 1.52 and 1.53):”the 1991 OFT review" and can be accessed at: http://www.competition-commission.org.uk/rep_pub/reports/1993/337gas.htm

15 The 1993 Office of Fair Trading (OFT) review can be accessed at: http://www.competition-commission.org.uk/rep_pub/reports/1993/337gas.htm

${ }^{16}$ The full Gas Act 1995 (c45) can be accessed at: http://www.opsi.gov.uk/acts/acts1995/Ukpga_19950045_en_1.htm

17 'Competition and regulation in the UK gas industry', Catherine Waddams Price, OUP, Oxford Review of Economic Policy, vol13, No1, 1997. This can be accessed at: http://oxrep.oxfordjournals.org/cgi/reprint/13/1/47.pdf (p54)
} 
Table 1: BG's declining market share (\%) 1990-1996

\begin{tabular}{|l|c|c|c|c|c|c|c|}
\hline Market & Oct '90 & Oct '91 & Oct '92 & Oct '93 & Dec '94 & Apr'95 & Jun'96 \\
\hline $\begin{array}{l}\text { Small firm supply } \\
(<2,500 \text { therms p.a.) }\end{array}$ & $\mathbf{1 0 0}$ & 100 & 100 & 77 & 52 & 45 & $\mathbf{4 3}$ \\
\hline $\begin{array}{l}\text { Large firm supply } \\
\text { (>2,500 therms p.a.) }\end{array}$ & $\mathbf{9 3}$ & 80 & 57 & 32 & 9 & 10 & $\mathbf{1 9}$ \\
\hline Interruptible (exc power) & $\mathbf{1 0 0}$ & 100 & 100 & 100 & 93 & 57 & $\mathbf{3 4}$ \\
\hline Power stations & No mkt & 9 & 26 & 12 & 17 & 32 & $\mathbf{2 4}$ \\
\hline TOTAL (exc power) & $\mathbf{9 7}$ & 91 & 81 & 77 & 47 & 35 & $\mathbf{2 9}$ \\
\hline
\end{tabular}

Source: OUP, Oxford Review of Economic Policy, vol13, No1, 1997

The process of transformation was completed when in 1996 the Network Code ${ }^{18}$ came into being. This statutory document sets out the rules and procedures for third party access to the British pipeline grid and introduced a regime of daily balancing.

This crucial turning point signified the start of the "new world", though there have been many more changes in the industry over the subsequent 14 years. BG PLC was voluntarily demerged into two separate companies: BG Group, which took over all of the upstream assets of the old company, and Centrica, all of the downstream assets. Transco was sold off from BG to National Grid. The storage activities of Transco were separated from the rest of the business and sold off to Dynegy, although after only a really brief period of "independence" these activities were bought back by Centrica, under the name of BG Storage Ltd.

There have since been many more regulatory interventions, including the merger of OFGAS and OFFER (the electricity regulator) to form OFGEM. A major infrastructure change to the network came in 1998 with the opening of the Interconnector pipeline between Belgium and the UK. ${ }^{19}$ This allowed for the first time ever a physical flow of gas between the British and Continental European gas grids. There have been other infrastructure developments, including the uni-directional BBL pipeline flowing gas from the Netherlands to Britain since December 2006, the opening of the Isle of Grain LNG regasification terminal in 2005, along with several upgrades since then and, after protracted delays in the completion of the Dragon and South Hook projects, the opening of two LNG import terminals at Milford Haven during the second half of 2009. There has also been Langeled, a major new Norwegian gas supply pipeline and the world's longest underwater line, delivering up to $25.5 \mathrm{Bcma}$ of gas to the Easington terminal and operational since October 2007.

The industry transformation from old world to new world was largely completed around 1998 when all customers in could choose their supplier, however large or small their consumption. There is genuine competition at all levels of the supply chain and, although there will continue to be many more amendments to the Network Code in future, there has been a fully liberalised gas market in Britain for over 10 years.

\subsection{British, Americans and Continental Europeans!}

Initially, the new market structures that were put in place by legislation and regulation did not in themselves create a high level of competition. What was needed was a growth in the number of participants.

\footnotetext{
${ }^{18} \mathrm{BG}$ plc was obliged, under the conditions of the BG Licence (as determined by the Secretary of State pursuant to section 8(2) of the Gas Act 1995[2]), to prepare a code governing the conveyance and storage of gas; BG plc prepared such a code ("the Network Code"). This Code has since been revised, amended and updated and was replaced in 2005 by the Uniform Network Code, a full description of which can be found in the chapter below: "NTS, Network Code and NBP"

19 'The Interconnector Pipeline: a Key Link in Europe's Gas Network', Mark Futyan, OIES, 2006
} 
New entrants were initially attracted to the end user market. Independent suppliers such as AGAS and United Gas, as well as the marketing affiliates of oil and gas producers such as Quadrant, Alliance, Kinetica, Amerada Hess and Mobil Gas Marketing, took advantage of the initial reductions in BG's market share and bought gas that BG released after the 1991 OFT review.

On the demand side, the power generators participating in the early 1990 s "dash for gas" 20 unleashed a wave of new gas-fired power generation capacity and needed to supplement their long-term purchase contracts with short term additional flexible volumes. The early deals were bilateral, but they soon formed the basis for an embryonic over-the-counter ${ }^{21}$ market in about 1994-1995, albeit still rather illiquid and opaque.

From about 1995, many more participants joined the "trading circle". 22 They were lured to the British market by the certainty given in the Gas Act (1995) that full competition was imminent. They included merchant banks, regional electricity companies, producers and trading houses, notably Enron and Accord. These two in particular brought American trading methods to the market, namely aggressive market making and price disclosure, which are both very important components to enabling the beginnings of a true traded market. Market making is where a trader will simultaneously quote both an offer and a bid price; price disclosure, usually through a trade publication, allows for greater transparency and therefore for confidence in trading that commodity. The varied mix of participants entering the market with their different trading agendas and risk appetites helped to greatly increase liquidity, thereby attracting further players.

At this time the UK's indigenous gas production was growing rapidly and created great pressure to reduce wholesale gas prices, which by the mid-to-late 1990s were on a downward trend. Spot prices were significantly below long-term contract prices, sometimes by as much as $30 \%$, allowing the new entrants to undercut established suppliers. This was arguably the defining point from which a return to the 'old world' was simply not possible. The number of participants in the British wholesale gas market increased from less than 15 in 1995 to more than 50 in about two years. After the opening of the Interconnector in 1998, allowing the physical flow of gas to and from the Continent, new European participants also started trading on the British market.

But perhaps the biggest change to the mix of participants in the British market occurred in 2001-2002; the collapse of Enron in the autumn of 2001 sent shock waves throughout the American trading houses, many of whom had bought UK assets.

This was followed only a year later, in October 2002, by the collapse of TXU Europe, which owned and operated one of the seven major UK generators (Eastern). The gas market lost a major participant and one which, being a major power generator, had been assumed to be robust. Confidence in gas trading sank to its lowest point. These two events conspired to significantly alter the makeup of the British gas market: the number of participants diminished as several 'trading houses' in particular opted to stay out of British gas trading and those companies that continued to trade did so within much stricter guidelines.

Traded volumes fell as participants sought to bolster their legal and financial counterparty arrangements. Prior to these two events, much trading had been conducted on the "my word is my bond" ethos but this

\footnotetext{
${ }^{20}$ The Dash for Gas was a phrase in common circulation in the 1990s; it described the massive shift to the use of gas in power generation, from the early part of that decade. The three main reasons for that shift were the privatisation of the electricity companies, that gas was allowed to be used as a generation fuel and, importantly, advances in generation technology in the form of cheaper and more efficient Combined Cycle Gas Turbines (CCGTs).

A full account can be read in: "When Systems are Overthrown: the Dash for Gas in the British Electricity Supply Industry", Mark Winskel, University of Edinburgh, 2002:

http://sss.sagepub.com/cgi/reprint/32/4/563

${ }^{21}$ OTC: see full explanation in the "Routes to Market" section p 24.

${ }^{22}$ This denotes the relatively small network of trading entities that had actually started to trade natural gas in Britain.
} 
could no longer satisfy risk managers! Market liquidity was therefore severely impaired, leading to some participants limiting their traders' exposures for fear of 'being stuck with a bad trade', ${ }^{23}$ which in turn created a vicious circle of diminishing volumes over a 2-3 year period. However, perhaps the most important consequence of these two events was that several American companies sought to exit the European markets and their UK gas and power assets were put up for sale.

During the period of flux from 2002 until about 2005, the void that was created by the Americans selling up was quickly filled. The market has since recovered and is arguably more resilient now compared with the pre-2005 period. European energy companies, seeing that their national monopolies or dominance was likely to be restricted under pro-liberalisation EU Energy Directives, quickly sought to diversify their corporate portfolios by buying up British assets from the Americans. In particular E.On, RWE, EDF and, more recently, GDF all now own significant gas and power assets in the UK.

Many more "financials" are now trading gas and electricity, including banks, financial institutions, hedge funds and even investment and pension funds. Other participants have started trading, creating a more varied market. It is estimated that there are, at the beginning of 2010 , about 80 participants in the British wholesale gas markets, creating once again a dynamic, active, traded market.

A good measure of a given market's liquidity and depth is the so-called "churn rate". This is a measure of the number of times a 'parcel' of the relevant commodity is traded and re-traded between its initial sale by the producer and final purchase by a consumer. There are several ways in which this number or ratio is calculated, depending on the statistics available, the overall transparency of the market in question and the specific methodology chosen by the compiler. However, they all show a very similar figure. As a 'rule of thumb', markets are generally deemed to have 'reached maturity' when the trading churn is in excess of 10 .

In the British gas market, churn rates reached a peak of 21 times in 2001 before easing off in the post Enron/TXU collapse of the market, as described earlier, with the churn falling to around just 8 times in 2005. However, as the market recovered, so did the churn rate; by August 2007 it was back at around the 20 times mark. In the next four years, it oscillated in the mid to high teens. Although less than the churn rate in the North American Henry Hub market, which has been as high as over 30 times, primarily due to the very high speculative volumes in that commodity, the NBP churn rate is still significantly higher than any other Continental European traded gas hub.

\section{NTS, Network Code and NBP}

After a brief introduction to the National Transmission System (NTS), we will, in this section, explain the importance of the Network Code and how the National Balancing Point (NBP) has helped to create the liquid, transparent, liberalised wholesale gas market we have in Britain today. We will explore the balancing and notification processes before finally looking at standardised trading under the NBP'97 contract.

\subsection{National Transmission System}

Before discussing the functioning of the traded gas market in Britain it is first necessary to describe the physical distribution network; the National Transmission System or NTS.

The National Transmission System (NTS) is the high pressure part of National Grid's transmission system and it consists of more than 6,600 kilometres of pipeline operating at pressures of 45 up to 85

\footnotetext{
${ }^{23} \mathrm{~A}$ Bad Trade is trader language for a deal that is or could become problematic in so far as it might not be honoured by the counterparty for whatever reason but especially if it ceased to exist/trade.
} 
bar. $^{24}$ The gas is moved through the system using 28 optimally located compressor stations. From over 140 off-take points, the NTS supplies gas to about 60 Direct Connect customers (about 40 power stations and about 20 large industrial consumers) and to the twelve Local Distribution Zones (LDZs) that operate at lower pressure supplying medium and small load consumers. ${ }^{25}$ These LDZs are now grouped administratively into four Distribution Networks (DNs) independently owned and managed but all complying with the strict parameters set out in the Uniform Network Code (UNC - see 'The Network Code' section on this page for more detail).

Gas travels through the network at an average of 25 miles per hour, so that additional supplies in response to a change in demand in one part of the country may not be instantly delivered; however, if the NTS is kept constantly in balance across all regions, the response time will be greatly diminished. This balancing is the role of the Transmission System Operator (TSO) - National Grid Gas - and is described further in the chapter on 'Balancing and Nominations' on page 9.

This extensive and complex infrastructure needs to be able to deal with very large variations in flows, from a 'low' demand day of around $160 \mathrm{mcm}$ in summer, to a winter's 'peak' demand day in excess of $450 \mathrm{mcm} .^{26}$ These seasonal highs and lows are national demand levels, on top of which there can be regional variations in demand and also fluctuations in the differing supply volumes coming into the NTS from the nine Entry Points around the country. There are also nine storage facilities, of differing sizes and flexibility, to help in the provisioning of gas and in the balancing of the system.

Appendix $\boldsymbol{A}$ shows a comprehensive map of the National Transmission System showing the high pressure pipeline infrastructure, along with the necessary compressors and regulators, the nine Entry Points or 'Terminals', the storage facilities, the import and/or export pipelines and the Exit or 'offtake' points where the gas flows out of the NTS and into the lower pressure distribution network of pipes. It also shows how the country is divided into the twelve Local Distribution Zones, operated by the four Distribution Networks.

\subsection{The Network Code}

The development of the Network Code was a fundamental enabler of the development of gas trading in Britain.

Its authority was enshrined in the Gas Act of 1995 and it first came into effect in March 1996, in two stages known as the "soft" and "hard" landings, reflecting the gradual severity of penalties imposed for being out of balance (see "balancing" in next chapter). The Network Code is effectively the set of rules and procedures for third party access to the British gas pipeline grid. It created the system of daily balancing and thereby a need for a short term traded market. In order to balance their portfolios on a daily basis, traders use 'standardised' contracts such as "Within-Day", "Day-Ahead", "Balance of Week", "Weekend" and "Working Days Next Week". These contracts are primarily used by traders for portfolio balancing ahead of delivery. ${ }^{27}$

\footnotetext{
${ }^{24}$ 45-85 times normal atmospheric pressure. This is equivalent to around 653-1233 psi.

${ }^{25}$ In 2009 the total number (all numbers have been rounded) of gas customers supplied by the NTS was 21,120,000 which comprised 20,800,000 small load (residential and small Industrial and Commercial), 300,000 medium load (Industrial and Commercial) and 20,000 large load (Large Industrial and Commercial and Direct Connect ) customers.

${ }^{26}$ The actual NTS Exit Flows on the Minimum Demand Day of Gas Year 2008/09 were 160mcm on 15 ${ }^{\text {th }}$ August 2009; the

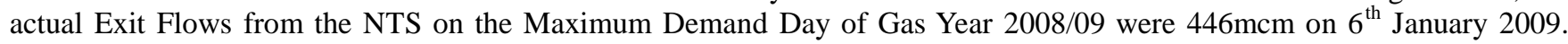
Source: National Grid Ten Year Statement 2009, appendices A3.3.3 and A3.3.4

The record demand of $449 \mathrm{mcm}$ set on $7^{\text {th }}$ January 2003 was finally exceeded on 7 th January 2010 when a new record Maximum Demand Day was set with actual Exit Flows of $454 \mathrm{mcm}$.

${ }^{27}$ Trading and contracts are explained in greater detail in the section "Natural Gas - the traded commodity" on page 19.
} 
The Network Code also gave rise to the Flexibility Mechanism, later to become the On-the-day Commodity Market (OCM). This mechanism was devised to allow the balancing agent (then Transco, now National Grid Gas) to trade with shippers in order to allow it to balance the system. Most importantly from a trading point of view, the Network Code introduced the National Balancing Point (NBP). The Network Code heralded the real beginning of gas trading in a liberalised environment in the UK and was succeeded in 2005 by an improved version called the Uniform Network Code (UNC). We will examine each of these points in the course of this paper.

We will start by looking at how the Network Code took balancing from a monthly to a daily regime. In the "old world", physical balancing of supply and demand was done on a monthly basis and took up to 15 days in arrears to settle. After introduction of the Network Code in 1996 there was an initial transition phase known as the "soft landing". During the first seven months of the new regime, from March 1996 to September 1996, shippers were obliged to start balancing on a daily basis. They were however allowed very generous volumetric tolerances before incurring penalty charges and, even if they did incur penalties, these charges were non-punitive and costed at the "System Average Price (SAP)".

This was necessary, not only because the methodology of daily balancing was very different from previous industry practices but, especially, because there were still significant data quality problems regarding supply point flows. Several off-shore producers, operating under a different regime to the onshore 'shippers', could each be flowing gas to the same import terminal but using different data records. Furthermore, these records were often incompatible with terminal data feeds. The situation needed to improve before something close to real daily balancing could be introduced.

System Average Prices (SAP) and System Marginal Prices (SMP) are determined by all the trading that National Grid Gas conducts on a given day on the OCM in its capacity as TSO and its obligation to physically balance the system. The volume- weighted average price of all those trades is called the SAP, whereas the highest and lowest prices traded by NGG become the marginal selling price (SMPs) and the marginal buying price $(\mathrm{SMPb})$ respectively (these terms are explained in greater detail in the next chapter).

After the initial seven month period came a second phase, known as the "hard landing". This phase, which started in October 1996 and took six years to fully introduce, saw the volumetric tolerances become increasingly stricter by reducing the amount of over- or under- delivery of gas that a shipper to the NTS could make compared to the nominations; more importantly, the imbalance penalties were now punitive charges based on the "System Marginal Price" (SMP).

The tolerances were quite complicated, with elements based on entry and exit flows (with different percentages applying to different classes of exit point, for example); with a Non Daily Metered (NDM) site deviation adjustment; and with absolute daily imbalance tolerance and cumulative cashout to allow for some roll over from day to day. These tolerances were progressively tightened and eliminated with a big reduction made in April 2001; the last tolerance in this regime, the NDM deviation adjustment, was finally eliminated in October 2002.

These soft and hard landings were designed to enable the smooth progression from monthly to daily balancing and to help allay the fears of shippers who initially were skeptical as to its feasibility. As well as the technical issues about the availability of accurate and timely data and the learning and implementation of new procedures, shippers needed to become confident that the within-day traded market had sufficiently developed to offer a vehicle that would deliver their need to balance their portfolios on a daily basis without fear of manipulation or difficulties in matching volumes.

Since October 2002 then, we have been firmly in the "new world" where all shippers have to accurately input and output gas to the grid on a daily basis or suffer financial penalties, and where National Grid Gas (the TSO) balances the NTS from a safety point of view. 
The Uniform Network Code ${ }^{28}$ replaced the Network Code in 2005 with a number of amendments and updates to reflect the experience gained from the first ten years of the liberalised market. The Network Code had moved the NTS from a monthly to a daily balancing regime for the shippers and now the UNC added clarity and detail in order to enable shippers and the system operator to balance more effectively. Indeed, it is a 'living document' and has continued to be updated and amended as and when necessary to allow for best practices and for the safe and efficient functioning of the Grid.

The UNC defined a new type of user alongside the existing shipper: this is the Distribution Network Operator (DNO). It also added a new type of capacity, "NTS Offtake Capacity": this is capacity at an NTS/LDZ (Local Distribution Zone) offtake point which can only be used by a distribution network user to take gas off the NTS. It constitutes a new form of capacity and can be in the form of either flat or flexible volume. Another key change brought about in the UNC was the obligation placed on DNOs to pass on to National Grid Gas their LDZ stock information, or any other relevant data in this respect, for the purpose of enabling NGG to carry out its system balancing activities.

\subsection{National Balancing Point}

The National Balancing Point or NBP is a virtual point or location created by the Network Code in order to promote the balancing mechanism detailed in the Code. It is where shippers nominate their buys and sells and where National Grid Gas balances the system on a daily basis. It is still the only example of its type in the world, with the possible exception of the Dutch TTF, which was created on a similar basis.

Although the NBP was created by the Network Code purely in order to allow the balancing of the system, it rapidly evolved as a trading point too. Traders had confidence in buying and selling gas on a standardised basis at the most liquid point in the UK's high pressure transmission system. This is in stark contrast to the 'old world', where gas was mostly traded at the Entry Points (more commonly known as "at the beach"). The NBP was used as the basis for the standardised "NBP'97" trading document, which has become the cornerstone of the British OTC traded market and also became the delivery point for the ICE futures natural gas contract.

\section{Balancing and Nominations}

We are now going to look at how balancing is used to maintain NTS linepack within safe parameters and, ultimately, to meet end user demand; and how nominations are used to notify National Grid Gas of expected gas flows and to seal a trade under NBP'97 terms.

\subsection{Balancing}

The balancing regime as set out in the Network Code puts the obligation on National Grid to balance the NTS physically within day. This was devised as, and is primarily, a safety issue, and requires National Grid Gas to maintain a safe pressure at all times in the NTS.

It discharges this Network Code obligation as "agent" on behalf of the shipper community and this activity is self-financing and does not form part of National Grid Gas's financial accounts. National Grid Gas is incentivised to balance the system at or close to the System Average Price (SAP) traded that day on the OCM: this is because it is acting as agent on behalf of all shippers and does not charge for balancing but can pass on its costs; therefore, the closer to SAP it can balance, the lesser its costs on that day. The objective is to make shippers who are out of balance bear the cost of the corrective sales and purchases. National Grid Gas can use several tools to balance the system as described below.

\footnotetext{
${ }^{28}$ The latest version of the Uniform Network Code can be accessed at: http://www.gasgovernance.co.uk/UNC
} 
Shippers on the other hand have the financial responsibility to balance their own deliveries and offtake daily. This is purely a commercial issue.

If a shipper is out of balance on a given day they will be cashed out at the System Marginal Prices (SMPs or SMPb), where:

- shippers who are short of gas are cashed out at SMPs, which is the highest price transacted by National Grid Gas that day on the OCM in its duty to balance the system

- shippers who are long of gas are cashed out at $\mathrm{SMPb}$ - the lowest price traded that day.

However, although not strictly allowed, some "retro trading" does occur, whereby a long shipper and a short shipper can agree to "transfer" gas between their accounts by altering their end of day volumes accordingly. This will normally be concluded at SAP.

The tools available to National Grid Gas to allow it to balance the system include linepack, the OCM, storage injections and withdrawals, interruptible capacity buyback and firm capacity buyback.

Linepack refers to the amount of gas 'squeezed' into the transmission network pipes at any given time; it therefore represents, in balancing terms, the operational flexibility within the NTS to run at lower or higher pressure, allowing National Grid Gas to increase or lower the total volume of gas in the system. However its ability to do this is strictly limited by physical safety constraints and in practice means that its operational flexibility is limited to plus or minus $10 \mathrm{mcm} /$ day at any given time. Linepack can also be used to balance or move gas over the whole NTS, which is sub-divided into 12 sectors, using a network of compressors and regulators.

The On-the-day Commodity Market (OCM) is the current successor to the original Flexibility Mechanism as set out in the Network Code. The OCM was introduced in 1999 as part of the New Gas Trading Arrangements and is a screen-based trading system (originally operated by EnMo) operated by APX-Endex. It is an anonymous cleared exchange, thereby offering zero counterparty risk. Shippers can be on one or both sides of a trade from 12 o'clock on D-1 up to 15.35 on D; thereafter National Grid Gas is always counterparty to every trade. This is because the OCM was designed as a system balancing tool. Within day trading on the OCM can be conducted until 4am on D. ${ }^{29}$

Storage adjustments and capacity buybacks form another aspect of the tools available to the TSO to balance the system. National Grid Gas can choose to withdraw from, or inject into, storage; it can also buy back from the shipping community capacity that had previously been sold for the transmission of gas into and out of the grid. If NGG ever needed to interrupt, it would initially invoke any interruptible contracts but could in extreme cases even buy back capacity which it had previously sold as 'firm'. This is because its balancing activities are determined by safety requirements. Capacity buybacks are usually carried out on a geographical basis to help balance the Grid across the regions if other methods have failed or are insufficient.

\subsection{Nominations}

The nominations procedure is conducted through 'Gemini', a dedicated computer system for trade nominations, operated by Xoserve on behalf of NGG. It went live in October 2005, replacing the previous 'in-house' National Grid system, AT-Link. Using a relatively simple Windows-style environment, Gemini phase two enables shippers to carry out gas nominations, energy balancing and exit capacity bookings. These activities lie at the heart of the commercial gas regime in Britain. Here, we will focus on gas nominations.

\footnotetext{
${ }^{29}$ 'D' simply refers to 'Day', the delivery day of gas; 'D-1' refers to the day before delivery; 'D+1' refers to the day after delivery. A day is defined as 24 hours from 06:00 to 05:59. See also 'M' in the Glossary.
} 
There are three main nominations categories used by shippers:

- into the NBP on an entry service, specifying the entry point, date and quantity;

- from the NBP on an exit service specifying the Daily Metered Site or exit point, date and quantity;

- from NBP to NBP, for gas trading, specifying the date and quantity.

NGG is responsible for calculating exit nominations at Non-Daily Metered sites.

As we are examining the evolution and functioning of the traded gas market in Britain we shall concentrate on the NBP to NBP nomination which, with its simplicity, has helped to encourage traders to participate at that location. An NBP trade nomination is defined in the "NBP'97" contract as follows:

'NBP Trade shall mean, in respect of a quantity of Gas, where:

a) In respect of any Day, Two users make corresponding Trade Nominations in respect of that quantity of Gas subject to and in accordance with Section C6 of the Network Code and

b) Neither Trade Nomination is amended or withdrawn thereafter the deduction by Transco of that quantity of Gas in determining for that Day the Daily Imbalance of the User making the Disposing Trade Nomination and the addition by Transco of that quantity of Gas in determining for the same Day the Daily Imbalance of the User making the Acquiring Trade Nominations'

Effectively this means that so long as a seller has input ('nominated') a certain quantity of gas on to Gemini and his buyer has input the equivalent quantity, or any like-for-like alteration, then the trade will stand.

\subsection{Standardised Trading and the NBP'97}

We mentioned earlier how standardised trading in the UK wholesale market had helped encourage liquidity in the market since 1997. It has relied upon a standardised contract known as the "Short Term Flat NBP Trading Terms \& Conditions", known affectionately as the NBP'97. This contract was the result of an industry working party set up some six months after the introduction of the Network Code following the rapid development of trading at the NBP and pressure from traders to have a common standardised trading contract.

In comparison to most legal documents it is very short, only eight pages, yet covering all aspects needed to trade gas at the NBP, from the practical terms (definitions, confirmation procedure, trade nominations, contract price, billing and payment,) to a few but necessary legal clauses. It may not be a perfect document, and there have been several, failed, attempts at bringing it up-to-date but it is still in use today, more than ten years since its creation. The NBP'97 contract is always for delivery of gas only at the NBP, so that traders only have to define the period of delivery, the quantity and the price, knowing that the location is in the British grid and that the quality of the gas will be within NTS specification.

As well as standardised billing and payment terms, the contract also has three very important features that enabled trading to develop and continue to be successful:

\section{Participants are 'kept whole', meaning that volumes delivered are guaranteed to equal volumes traded}

This is an important concept which distinguishes the NBP'97 contract from its upstream counterparts, which have 'swing' or an element of volumetric (usually buyer's) optionality included in them. Trading at the NBP is also different to trading at most European hubs where the volume traded is not guaranteed and may be pro-rated depending on actual physical flows on that particular day; 


\section{Quantities traded are "flat", meaning that the volumes traded are delivered at a constant flow rate throughout the delivery period}

There is no interruption or volume tolerance permitted, again unlike upstream contracts which will very often be subject to 'Take Or Pay' clauses and where daily variances in quantity are common either because of the buyer exercising 'swing' rights, or the seller declaring shortfalls;

\section{Thirdly and most importantly, there is very limited force majeure (FM) ${ }^{30}$}

There is no relief from the obligation to deliver or take gas from the NTS. An upstream field shut down or exit point problem does not constitute FM. The only FM allowed under the NBP-97 contract is an event beyond the control of the affected party, resulting in the inability to get a trade nomination into Gemini or accepted by Xoserve (NGG). Even in this event reasonable endeavours are required to overcome the FM, such as making a telephone call or sending a facsimile. However, if this 'extraordinary' event continues for seven days or more, either party can give three days' notice of termination. In reality therefore there is effectively no FM. This is unique to trading at the NBP and confers confidence on traders to participate in the British market.

The payment terms are clear and straightforward, allowing for VAT to be paid only on the net delivered volumes of gas, meaning that speculative traders who balance their books before contract expiry will not be liable to VAT payments. Suppliers' invoices are to be paid by the 20th of the month following delivery $(\mathrm{M}+1)$. Most participants have netting agreements which will allow for just one invoice and payment per month.

A copy of the "NBP'97" contract appears in Appendix $\boldsymbol{B}$.

\section{The Functioning of Today's Traded Market}

In this section, after a brief overview of natural gas as a physical and traded commodity today, a discussion of the main participants in the market and their roles, and the supply/demand and liquidity position, we will explore the reasons for trading and the various routes to market, along with the methods of trading, concluding with the contractual documentation needed to trade and market transparency.

\subsection{Natural Gas - the Physical Commodity}

Natural gas in the UK plays a significant role in the country's energy mix. After many years of being on a par with oil, gas has once more overtaken oil to be the largest source of primary energy. The figures for 2009 show that oil made up $37.41 \%$ of the UK's primary energy needs, whilst gas accounted for $39.16 \%$ and coal's share continues to diminish, at $14.93 \%$. Natural gas' share of primary energy in the UK is greater than it is in North America (27.65\%). The figure for the whole of Europe and Eurasia is $34.40 \%$. Indeed, apart from the Middle East and a few other, mainly energy producing, countries where the share of gas in primary energy can be greater than 50\%, natural gas in the UK has one of the largest shares of primary energy in the world. ${ }^{31}$

\footnotetext{
${ }^{30}$ Force Majeure literally means "greater force". FM clauses in contracts excuse a party from liability if some unforeseen event beyond the control of that party prevents it from performing its obligations under the contract.

${ }^{31}$ Primary energy sources: BP Statistical Review 2009/Author's calculations.
} 
Figure 1: Components of primary energy in $2009(\%)$

\section{UK Primary Energy Mix 2009}

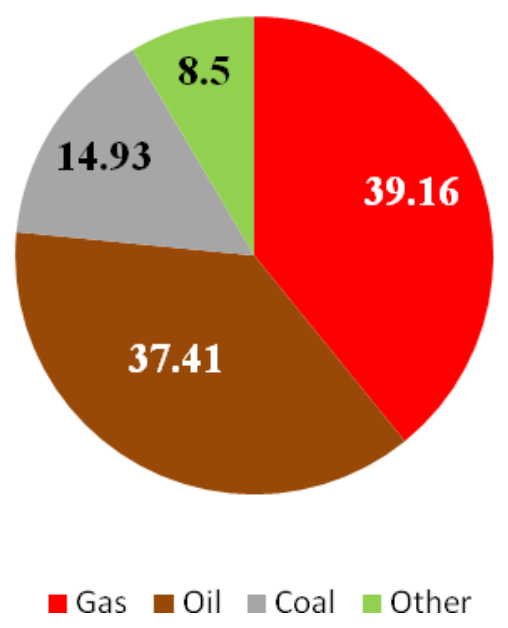

North American Primary

Energy Mix 2009

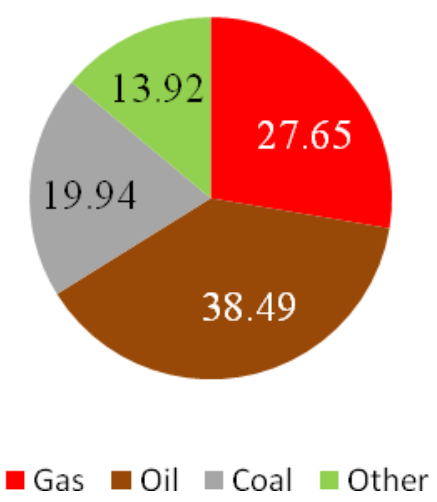

Europe/Eurasia Primary

Energy Mix 2009

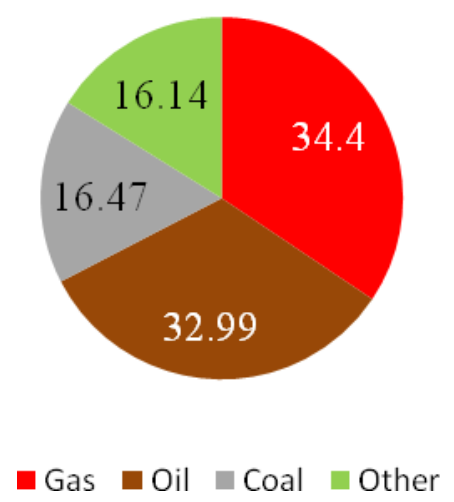

Source: Author's calculations

UK annual demand ${ }^{32}$ in 2009 was $93.1 \mathrm{Bcm}$, which is equivalent ${ }^{33}$ to approximately 95.6 million therms/day. This is a drop of nearly $10 \%$ from the 2008 figure of $102.1 \mathrm{Bcm}(\sim 104.8 \mathrm{mtpd})$, largely due to the effects of the economic recession and a lower demand from industry and the power sector. The forecast for 2010 is for the demand level to remain unchanged from 2009 levels. The use of natural gas has increased greatly from the 1990s with many indigenous North Sea fields coming on stream coupled with the building and commissioning of gas-fired power stations.

Table 2 gives a summary of the generation mix for the past ten years. Whilst nuclear has more than halved to less than $15 \%$, gas and coal have vied with each other to 'fill the gap' left by that fall, with the balance coming from renewables, oil and other sources. As older nuclear and coal stations are decommissioned in the 2010's, part of this capacity is likely to be replaced by gas, thereby increasing further its share of the power generation mix.

\footnotetext{
${ }^{32}$ Demand sources: IEA/OIES/Author's calculations.

${ }^{33}$ Conversion tables can be found in Appendix $\boldsymbol{C}$.
} 
Table 2: Fuel used in electricity generation: selected years 1998 - 2008

\begin{tabular}{|l|l|l|l|l|l|l|l|l|l|l|l|}
\hline \% & 1998 & 1999 & & 2001 & 2002 & 2004 & 2005 & 2006 & 2007 & $\mathbf{2 0 0 8}$ \\
\hline Gas & 28.08 & 33.52 & 31.68 & 33.86 & 34.11 & 31.64 & 30.45 & 35.82 & 39.23 \\
\hline Coal & 36.58 & 31.52 & 37.21 & 35.38 & 36.70 & 37.62 & 41.00 & 38.83 & 36.14 \\
\hline Nuclear & 28.59 & 28.96 & & 24.48 & 24.07 & & 21.27 & 21.34 & 19.58 & 16.57 & 14.09 \\
\hline
\end{tabular}

Source: BERR Energy Trends/Author's calculations

The balance between coal and gas has constantly been shifting depending on the relative cost of the two fuels. In 2006 coal was taking $>40 \%$ share but gas is redressing the balance with figures for 2008 showing that gas has not only overtaken coal for the first time since 1999 but has also achieved its highest ever usage at $>39 \%$.

Furthermore, in order to satisfy European environmental directives, the burning of coal (and oil) is becoming subject to increasingly tighter controls and financial penalties, meaning that it will become even less attractive to the generators as a source of fuel. The primary legislation here is the Large Combustion Plant Directive (LCPD) of $2001 ;{ }^{34}$ this Directive aims to reduce acidification, ground level ozone and particle emissions throughout Europe by controlling emissions of sulphur dioxide $\left(\mathrm{SO}_{2}\right)$ and nitrogen oxides (NOx) and dust (particulate matter (PM)) from large combustion plants (LCPs) in power stations, petroleum refineries, steelworks and other industrial processes running on solid, liquid or gaseous fuel.

All combustion plant built after 1987 must comply with the emission limit values (ELVs) as set out in the Directive. Those power stations in operation before 1987 (namely coal and oil in the UK) are defined as 'existing plant'. Existing plant can either comply with the LCPD through installing emission abatement (Flue Gas Desulphurisation) equipment or 'opt-out' of the directive. An existing plant that chooses to 'opt-out' is restricted in its operation from $1^{\text {st }}$ January 2008 to a maximum of 20,000 hours and in any event must close by $31^{\text {st }}$ December 2015 .

In the UK, twelve coal-fired power stations have opted-in and will be subject to the ELVs; they account for a total of 20,677MW of installed capacity. Six coal-fired power stations have opted out, as listed in Table 3, with an installed generation capacity of 8,672MW. Furthermore, there are three oil-fired stations that have opted out, with an installed generation capacity of 3,595MW. This makes a total of $12,267 \mathrm{MW}$ of installed generation capacity that will be taken off the grid by the end of 2015 at the latest.

\footnotetext{
34 'Directive 2001/80/EC of the European Parliament and of the Council of $23^{\text {rd }}$ October 2001 on the limitation of emissions of certain pollutants into the air from large combustion plants':

http://eur-lex.europa.eu/LexUriServ/site/en/oj/2001/1_309/1_30920011127en00010021.pdff
} 
Table 3: Power stations which have 'opted out' of the LCPD

\begin{tabular}{|c|c|c|}
\hline Installation & Operator & Opted-out capacity (MW) \\
\hline Ferrybridge* & SSE & 1000 \\
\hline Didcot A & RWE & 2000 \\
\hline Tilbury* & RWE & 1520 \\
\hline Kingsnorth* & E.ON & 2000 \\
\hline Ironbridge & E.ON & 1000 \\
\hline Cockenzie & Scottish Power & 1152 \\
\hline $\begin{array}{l}\text { *This capacity will be wholly or } \\
\text { partially replaced by new coal- } \\
\text { fired generation }\end{array}$ & Total Coal & 8672 \\
\hline Fawley & RWE & 1000 \\
\hline Littlebrook & RWE & 1245 \\
\hline \multirow[t]{2}{*}{ Grain } & E.ON & 1350 \\
\hline & Total oil & 3595 \\
\hline \multicolumn{2}{|c|}{ TOTAL OPTED-OUT CAPACITY } & 12267 \\
\hline
\end{tabular}

Sources: BERR/Environment Agency/RWE/E.On

http://www.berr.gov.uk/files/file37586.pdf

http://www.environment-agency.gov.uk/business/sectors/32613.aspx

http://www.rwe.com/web/cms/en/97626/rwe-npower/about-us/our-businesses/power-generation/fawley/

http://www.rwe.com/web/cms/en/97638/rwe-npower/about-us/our-businesses/power-generation/littlebrook/

http://www.eon-uk.com/about/968.aspx

The industrial sector gas demand has been affected by the 2008-2009 economic recession with some estimates showing a fall of around $10 \%$. Although this is not likely to recover very much, if at all, over the course of this decade, the fall in industrial demand is expected to be compensated by the rise in power sector demand. There is also a high residential penetration of gas which is most likely to remain stable in the near term, despite efficiency measures, as the population increases.

The UK is supplied with natural gas from indigenous North Sea production and from imported gas, the share of which has steadily been increasing as domestic supplies have declined since 2000. In the future the UK will need to rely increasingly on imported gas, with the latest estimates by National Grid indicating that imports will rise from $40 \%$ of demand in 2008 to about $60 \%$ of expected demand in 2015 and possibly greater than $80 \%$ by 2020 . These imports will come in the first instance from increased pipeline flows from Norway and Continental Europe (which will redirect pipeline supplies from Netherlands, Norway, Russia and LNG). 
The supply of gas from the UK Continental Shelf (UKCS) has had a relatively short life, due mainly to the rapid exploration and recovery regime employed. Peak production of around $108 \mathrm{Bcm}$ was achieved in 2000 , and volumes remained in a 'plateau' phase above $100 \mathrm{Bcma}$ for the next three years. Since 2003 though, there has been a $42 \%$ fall in output to just $59.6 \mathrm{Bcm}$ in 2009 and production is estimated to fall to around $45 \mathrm{Bcm}$ in 2015 and as low as around $25 \mathrm{Bcm}$ in $2020{ }^{35}$

Figure 2: UKCS production and gas reserves: 1999 - 2019

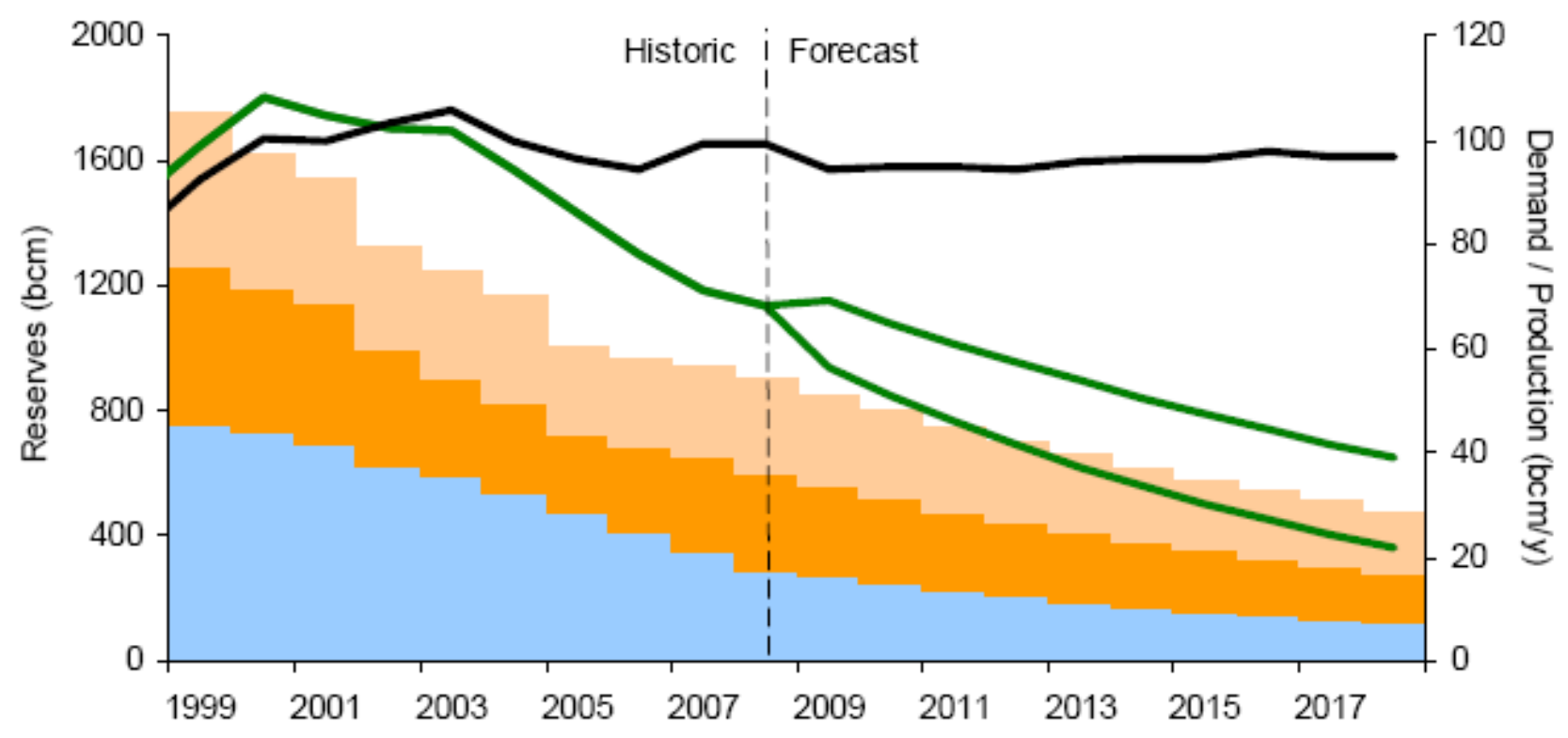

Proven $\_$Probable $\amalg$ Possible $\longrightarrow$ Net Production Range $\longrightarrow$ NTS Demand inc Exports

\section{Source: National Grid TYS 2009}

The other major North Sea producer is Norway which has followed a very different strategy for extracting natural gas from the Norwegian Continental Shelf (NCS). It has been a consistent supplier of gas to Continental Europe and to the UK, and operates an extensive infrastructure of pipelines in the North Sea to distribute the gas to market, including the Langeled pipe which became fully operational in 2007. This pipe alone has the capacity to deliver $25.5 \mathrm{Bcma}$ to the UK and is the world's longest underwater gas pipeline. Although the total export capacity of NCS gas to the UK is some $48 \mathrm{Bcma}$, Norway actually delivered $23.7 \mathrm{Bcm}$ in 2009.

The IUK and BBL interconnectors between the UK and the Continent have added to the 'spider's web' of pipelines in the southern North Sea. The major effect is to provide extra pipeline delivery flexibility in the North West Europe area, allowing for both forward and reverse flow of gas. The volumes transported could be either as a result of contracts between the Britain and the Continent, or for transit of supplies from Norway or even LNG to the Continent.

\footnotetext{
${ }^{35}$ BP Statistical Review 2010/National Grid TYS 2009
} 
Table 4: UK import infrastructure as of Q1 2010 - existing and under construction

\begin{tabular}{|c|c|c|c|c|c|}
\hline Import Project & $\begin{array}{l}\text { Operator } \\
\text { /developer }\end{array}$ & Type & $\begin{array}{l}\text { Commissioning } \\
\text { Date }\end{array}$ & $\begin{array}{l}\text { Landfall in the } \\
\text { UK }\end{array}$ & $\begin{array}{l}\text { Capacity } \\
\text { (Bcma) }\end{array}$ \\
\hline $\begin{array}{l}\text { Belgian } \\
\text { Interconnector }\end{array}$ & IUK & Pipe & 1998 & Bacton & 25.5 \\
\hline $\begin{array}{l}\text { Dutch } \\
\text { Interconnector }\end{array}$ & BBL & Pipe & 2006 & Bacton & 15 \\
\hline Vesterled & Gassco & Pipe & 2003 & St Fergus & 13 \\
\hline Tampen 10 & Gassco & Pipe & 2007 & St Fergus & 10 \\
\hline Langeled & Gassco & Pipe & 2007 & Easington & 25.5 \\
\hline Isle of Grain $1+2$ & National Grid & LNG & 2005 & Isle of Grain & 13.5 \\
\hline Gasport & Excelerate & LNG & 2007 & Teesside & $\sim 4$ \\
\hline Dragon & BG/Petronas & LNG & 2009 & Milford Haven & 6 \\
\hline \multirow[t]{2}{*}{ South Hook 1} & QP/ExxonMobil & LNG & 2009 & Milford Haven & 10.5 \\
\hline & & & & Total existing & $\sim 123$ \\
\hline South Hook 2 & QP/ExxonMobil & $\mathrm{LNG}$ & Milford Haven & 2010 & 10.5 \\
\hline \multirow[t]{3}{*}{ Isle of Grain 3} & National Grid & LNG & Isle of Grain & 2010 & 7 \\
\hline & & & & $\begin{array}{l}\text { Under } \\
\text { construction }\end{array}$ & $\mathbf{1 7 . 5}$ \\
\hline & & & & $\begin{array}{l}\text { Total existing } \\
\text { and under } \\
\text { construction }\end{array}$ & 140.5 \\
\hline
\end{tabular}

Source: National Grid TYS 2009/Author's calculations

The biggest potential change to the supply mix of gas for the UK is the result of the building of several LNG receiving terminals and, indeed, the possibility of more in the future. However, LNG is not new to the UK: the world's first LNG receiving terminal was commissioned in 1959 at Canvey Island but the deliveries of Algerian LNG were phased out by the mid-1980s, ahead of the increasing UK North Sea gas supplies.

In the 'new era' of UK LNG import capacity, the first terminal to be commissioned was at Isle of Grain in 2005, with an initial capacity of 4.4Bcma, rising to $13.5 \mathrm{Bcma}$ in 2008 and with a planned $3^{\text {rd }}$ phase of an additional 7Bcma in 2010/11. Then, in 2007, the Excelerate terminal was commissioned, an offshore floating jetty for onboard re-gas vessels, allowing for up to $4.4 \mathrm{Bcma}$.

Finally, the Milford Haven complex in South Wales started commissioning from 2009. The Dragon terminal has a capacity of 6Bcma and the South Hook terminal, part of the Qatar Petroleum/ExxonMobil 
QG2 project, a capacity of $10.5 \mathrm{Bcma}$ in phase 1, with a further $10.5 \mathrm{Bcma}$ in phase 2, due from 2010. This means that by the end of 2010, the UK will have a total LNG import capacity of over 50Bcma, or in excess of half of UK demand.

Table 5: UK import infrastructure: proposed

\begin{tabular}{|c|c|c|c|c|c|c|}
\hline $\begin{array}{l}\text { Import } \\
\text { Project }\end{array}$ & Developer & Type & $\begin{array}{l}\text { Landfall } \\
\text { location }\end{array}$ & Date & $\begin{array}{l}\text { Capacity } \\
\text { (Bcma) }\end{array}$ & Status \\
\hline BBL expansion & BBL & Pipe & Bacton & $2010 / 12$ & 3 & FID* taken \\
\hline Dragon 2 & BG/Petronas & $\mathrm{LNG}$ & $\begin{array}{l}\text { Milford } \\
\text { Haven }\end{array}$ & $2013+$ & 6 & $\begin{array}{l}\text { Planning permission } \\
\text { received for } 1 \text { extra } \\
\text { tank }\end{array}$ \\
\hline Port Meridian & Hoegh LNG & LNG & $\begin{array}{l}\text { Offshore } \\
\text { Barrow }\end{array}$ & 2013 & 4 & $\begin{array}{l}\text { Most planning } \\
\text { granted, no FID* }\end{array}$ \\
\hline ConocoPhillips & Consortium & LNG & Teesside & $2014+$ & $7+$ & $\begin{array}{l}\text { Most planning } \\
\text { granted, no FID* }\end{array}$ \\
\hline Canvey LNG & Consortium & LNG & $\begin{array}{l}\text { Canvey } \\
\text { Island }\end{array}$ & $2014+$ & $5.4+$ & $\begin{array}{l}\text { Planning rejected, } \\
\text { potential resubmission }\end{array}$ \\
\hline Isle of Grain 4 & $\begin{array}{l}\text { National } \\
\text { Grid }\end{array}$ & LNG & $\begin{array}{l}\text { Isle of } \\
\text { Grain }\end{array}$ & & & $\begin{array}{c}\text { Open season } \\
\text { underway }\end{array}$ \\
\hline & & & Proposed & & $25+$ & \\
\hline
\end{tabular}

Source: National Grid TYS 2009

$*$ FID $=$ Final Investment Decision

Taking into account the various LNG terminals or upgrades being proposed, the possible import capacity by the late 2010 s could be as high as $75 \mathrm{Bcma}$. So far, the number of participants has already increased from just two (BP and Sonatrach) when Isle of Grain first opened in 2005, to ten when all the current projects are operational (BP, Sonatrach, Centrica, GDF Suez, South Hook Gas, BG, Petronas, E.ON, Iberdrola).

There is no doubt therefore that LNG will play an important and increasing part in the gas supply mix to the UK. This will help counter the declining UKCS production and be a valuable contributor to the country's security of supply. LNG has the ability to respond quickly to market signals, both on a global scale but also within the North West European market as, unlike pipeline gas, it is not fixed to one destination. The important factor here is that there will be a large amount of built capacity and a good network of connecting pipelines to allow for onward distribution.

The Qatari QG2 project's South Hook terminal at Milford Haven is the UK's largest single LNG import terminal. With a capacity of at least $21 \mathrm{Bcma}$, this terminal alone could account for one fifth of UK demand. South Hook is just one part of the integrated whole value chain business model that Qatar has adopted in the monetisation of their gas reserves. Its ability to export LNG to each of the three main global demand zones will allow it to commercially risk manage their portfolio, responding to the various pricing signals and thereby eliminating physical imbalances between these regions. Ultimately this should be seen as a bonus for the UK in knowing that its facilities will be used to their commercial optimum which, in turn, will help to provide security of supply. 


\subsection{Natural Gas - the Traded Commodity}

Gas is brought into the national grid physically at System Entry Points, but is traded most commonly at the NBP. The IEA estimated in 2007 that just over $50 \%$ of the gas consumed in the UK had been traded; this figure has remained steady up to $2010 .^{36}$

Britain's NBP is by far the most liquid trading hub in Europe, as detailed in Table 6.

Table 6: Traded and physical volumes at European hubs

\begin{tabular}{|c|c|c|c|c|c|c|c|c|c|}
\hline \multicolumn{2}{|l|}{ bcm per year } & \multirow{2}{*}{$\begin{array}{l}\text { NBP } \\
\text { (‘96) } \\
611.0\end{array}$} & \multirow{2}{*}{$\begin{array}{c}\begin{array}{c}\text { Zeebrugge } \\
\text { ('00| }\end{array} \\
38.6\end{array}$} & \multirow{2}{*}{$\begin{array}{c}\text { TTF } \\
\text { (‘03) } \\
2.3\end{array}$} & \multirow{2}{*}{$\begin{array}{c}\text { PSV } \\
\text { ('03) } \\
0.1\end{array}$} & \multirow[t]{2}{*}{$\begin{array}{l}\text { PEG's } \\
\text { (‘04) }\end{array}$} & \multirow[t]{2}{*}{$\begin{array}{c}\text { BEB } \\
(' 04)\end{array}$} & \multirow[t]{2}{*}{$\begin{array}{l}\text { CEGH } \\
\text { ('05) }\end{array}$} & \multirow[t]{2}{*}{$\begin{array}{l}\text { EGT } \\
\text { ('06) }\end{array}$} \\
\hline Traded volume & 2003 & & & & & & & & \\
\hline & 2004 & 551.9 & 41.1 & 6.2 & 1.1 & 0.3 & 0.0 & & \\
\hline & 2005 & 500.1 & 41.7 & 11.6 & 2.6 & 4.0 & 0.4 & 0.8 & \\
\hline & 2006 & 615.2 & 45.1 & 19.1 & 7.1 & 7.0 & 1.2 & 8.9 & 0.2 \\
\hline & 2007 & 902.6 & 40.2 & 27.3 & 11.5 & 11.1 & 4.8 & 17.7 & 6.6 \\
\hline & 2008 & 960.8 & 45.4 & 60.2 & 15.6 & 16.5 & 9.7 & 14.9 & 25.3 \\
\hline \multirow[t]{6}{*}{ Physical volume } & 2003 & 52.5 & 10.2 & 1.3 & $n / a$ & & & & \\
\hline & 2004 & 53.2 & 10.6 & 2.3 & $\mathrm{n} / \mathrm{a}$ & $\mathrm{n} / \mathrm{a}$ & $\mathrm{n} / \mathrm{a}$ & & \\
\hline & 2005 & 53.7 & 8.4 & 3.8 & $\mathrm{n} / \mathrm{a}$ & $\mathrm{n} / \mathrm{a}$ & $\mathrm{n} / \mathrm{a}$ & $\mathrm{n} / \mathrm{a}$ & \\
\hline & 2006 & 60.6 & 8.6 & 5.9 & $\mathrm{n} / \mathrm{a}$ & $\mathrm{n} / \mathrm{a}$ & $\mathrm{n} / \mathrm{a}$ & $\mathrm{n} / \mathrm{a}$ & 0.1 \\
\hline & 2007 & 66.8 & 7.9 & 7.4 & 6.8 & $\mathrm{n} / \mathrm{a}$ & $\mathrm{n} / \mathrm{a}$ & 6.9 & 4.1 \\
\hline & 2008 & 66.6 & 9.1 & 18.7 & 7.7 & $\mathrm{n} / \mathrm{a}$ & $n / a$ & 5.2 & 14.4 \\
\hline
\end{tabular}

Note: the year quoted under each hub is the year of first operation.

Source: IEA 2009 Natural Gas Review, p.30.

Gas is a traded commodity in its own right in Britain, in a fully liberalised, fully open marketplace where regional and global prices are important but gas market fundamentals still bear more heavily on pricing. These fundamentals include the actual supply and demand situation on any given day, and the expected physical balance over the coming seasons, not only for natural gas itself but also for other related and/or competing energy products, such as oil, electricity and coal. With the ever-greater importance of environmental issues, the price of carbon is also a major factor, especially in determining the generation fuel mix. Finally, the market is susceptible to short term factors such as weather-related demand variations and upstream supply problems.

Prices are therefore likely to be more volatile at times, especially in the spot market, and will rapidly change according to prevailing supply/demand perceptions: these could be influenced by unplanned maintenance, unusual weather, transportation issues or simply relevant news items. There is very transparent volume and price information in the British gas market which in turn enables many different types of traders to participate and allows the regulator to ensure fair play.

The $50 \%$ of gas not traded is sold and purchased on longer term contracts. ${ }^{37}$ We will look at the various contracts that have existed in the chapter on "Price Drivers" on page 29. But the current "post-2000" contracts have been spurred on by fears of insecurity of supply as the country becomes more and more dependent on imported gas. Buyers, therefore, seek to secure volumes of gas over the medium term with contracts of 8-12 years, even though the pricing of that gas is nearly always indexed to the NBP price

\footnotetext{
${ }^{36}$ IEA 2007 Natural Gas Review, p.208.

${ }^{37}$ IEA 2007 Natural Gas Review, p.208.
} 
nearer the time of delivery, usually on a 'month ahead' basis. These are bilateral negotiated deals, but within a competitive market framework, echoing the traded "OTC" market, being mostly flat gas and delivered at the NBP, with limited FM on both parties.

\subsection{Main Participants}

After a period in the doldrums from 2002 to 2004 following the Enron and TXU debacles, the British traded gas market has seen a distinct renewal of interest and today numbers over 80 counterparties, of which some 30 or so can be considered active players, intervening in the traded market on a daily basis. This underpins the favourable liquidity existing in today's market at the start of the 2010s. These participants can be classed into four main categories: banks and funds, producers, end users, and proprietary traders. The most active participants in each of these categories as of Winter 2009 are shown in Table 7.

Table 7: Main UK-based participants in the British gas market

\begin{tabular}{|l|l|}
\hline Banks and funds & Producers \\
$\begin{array}{l}\text { J.Aron(GoldmanSachs), Barcap, BNP, Calyon, } \\
\text { Centaurus, Citadel, Citibank, Credit Suisse, } \\
\begin{array}{l}\text { Deutsche, Elliott Advisors, Macquarie, Merrill } \\
\text { Lynch, } \\
\text { JP Morgan, Morgan Stanley, Nomura, Tudor }\end{array}\end{array}$ & $\begin{array}{l}\text { BG Group, BP, Conoco, ENI, ExxonMobil, } \\
\text { Gazpom(GM\&T), Shell, Statoil, Total }\end{array}$ \\
\hline $\begin{array}{l}\text { End-users } \\
\text { Accord(Centrica), EDF Energy, Eon, RWE, } \\
\begin{array}{l}\text { Scottish Power, } \\
\text { Scottish \& Southern, Smartest, Wingas (UK) }\end{array}\end{array}$ & $\begin{array}{l}\text { EDF Trading, Gunvor, Hetco, Koch, Mercuria, } \\
\text { Noble, Vitol }\end{array}$ \\
\end{tabular}

Source: Author

Over the past 15 years or so since liberalisation, the two "physical" categories of producers and end users have diminished in number, primarily through industry consolidation. The category of proprietary traders reduced after the Enron collapse, but some new companies have since entered the market. But despite the economic recession, the category that has grown most in the late 2000s is that of the banks and funds. There are also a number of Continental European players and this category has also grown in the late 2000s. Finally, there are three main OTC brokers to help facilitate trading, with a fourth, GFI, joining the group in 2009, with as yet a small percentage share. These two categories are shown below. 


\begin{tabular}{|l|l|}
\hline European Players & Brokers \\
\hline Alpiq, Distrigaz, Dong, EGL, & \\
Electrabel, Enbw, & ICAP \\
EON/Ruhrgas, & Prebon \\
Gaselys(SocGen/GdF-Suez), & Spectron \\
Gasterra, Statkraft, & \\
Vattenfall, Verbund, Wingas & \\
\hline
\end{tabular}

Source: Author

Other participants who trade British gas in varying degrees include:

- the TSO which, on a daily basis, will trade in order to balance the network;

- institutional investors such as insurance companies who tend to include commodities as a small percentage of their portfolio;

- private investors or speculators who are attracted when volatility is high;

- commodity traders or 'locals' who trade for a living and will include British gas when the potential returns look attractive.

\subsection{Reasons for Trading}

It is important to be able to understand why one would need or want to trade before actually setting about transacting. There are several reasons why a company would want to trade: to buy or sell gas to balance a physical portfolio; as a financial hedge; or as speculation. This in turn will determine which route to follow.

\section{Physical purchase/sale}

Probably the most obvious reason for trading is simply to sell or buy a quantity of goods to satisfy the 'core business'. The volume will be dependent on anticipated consumption, production or sales forecasts. More trading will be done to 'fine tune' the actual quantities as the delivery date approaches. As this is a continuous cycle with most businesses, then there will be many 'layers' of trading at any one time.

Physical trades can be done in many ways from bilaterally negotiated deals direct between two counterparties, to trading on the OTC forwards market and even, in some cases, by trading futures contracts that permit delivery at expiry. These are the "Routes to market" illustrated in Figure 4 below. Trades can be transacted for immediate delivery or for delivery at a time in the future, in some cases for as much as 20 or more years forward as with the Long Term Contracts in European gas.

Also, a varying proportion of the spot trading on any given day will be done by the TSO (National Grid Gas) which has the duty to balance the system. These will all be physical trades transacted purely to keep the network in safe balance at all times.

\section{Financial Hedge}

In simple terms, financial hedging is used purely to safeguard profit margins on predicted forward business. Having established the level of future physical trading needed, financial hedging can then be used to lock in the predicted profit margin between the cost of production and the sales income. This way, whatever the changes in the market place between the time of striking the deal (or forecasting future cash flow and profit margins) and the time of delivery, the profit margin will remain the same. 


\section{Basic producer price risk management: short futures hedge}

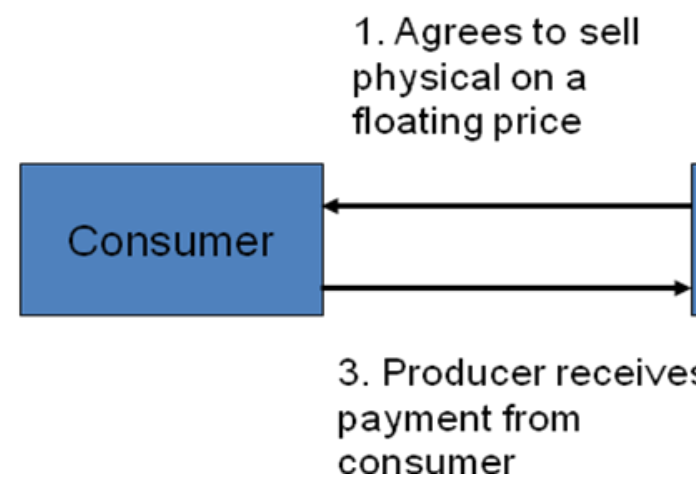

Source: Author
2. Sells futures

contracts to

cover liability

Hedging is the opposite of speculation, as hedgers are not trying to "win" in the markets by making money on price moves but are simply securing a price today for future delivery to allow for better focus on planning and business development with minimum exposure to unwanted price risk. Hedging can vary in complexity from relatively simple 'off-setting' trades as shown in Figure 3, through to complex derivative structures.

To hedge is to take a futures position that is equal and opposite to a position held in the cash market. The objective is to mitigate the risk of an adverse move in prices. Hedging works in mitigating price risk because futures prices and cash prices ${ }^{38}$ are highly correlated. Hedging using futures very seldom results in physical delivery against the futures contract; contracts are liquidated via offset and do not result in delivery. The purpose of the delivery provision is to ensure convergence between futures price and the cash market price. It is the threat of delivery that causes these prices to come together.

\section{Example of how a company can protect its profit margin through hedging:}

In March, a producer of widgets (W) is planning his winter sales strategy and determines the following sales and profit target for the month of December:

He observes that the current OTC forward December price for raw materials (RM) is 400 .

$\mathrm{He}$ is told that the anticipated wholesale price for $\mathrm{W}$ is 1000 .

He will need to buy $x$ raw materials (RM) to make and sell y widgets (W), resulting in a projected profit (P) of 600 . It is this $P$ of 600 that he will want to protect.

RM has an active OTC market as well as an Exchange futures contract.

The sales of $\mathrm{W}$ are conducted by wholesalers on behalf of the producers.

In this example the price of $\mathrm{W}$ is closely correlated to the cost of RM.

The producer could enter into contracts now with his RM supplier and W wholesaler to 'lock in' P but... his wholesaler does not want to commit to a price in March and only agrees to take the y Widgets at the prevailing market price at the time of delivery in December (floating price contract).

\footnotetext{
${ }^{38}$ Cash in trading terms refers to the underlying physical commodity.
} 
Therefore, in order to protect his anticipated profit margin, the producer will enter into a forward sales contract with the wholesaler on a floating price basis; he will also buy x RM on the forward OTC market to be sure of both quantity and price of the raw materials. Finally, he will at the same time sell $\mathrm{x}$ $\mathrm{RM}$ on the futures market to protect his profit margin against a change in the cost of RM, whether it be up or down. A summary of these transactions is shown in Table 9.

Table 9: Hedging: 3 example scenarios and $p+l$ accounts

\begin{tabular}{|c|c|c|c|c|}
\hline & $\begin{array}{l}\text { RM } \\
\text { OTC }\end{array}$ & $\begin{array}{c}\text { RM } \\
\text { futures }\end{array}$ & $\begin{array}{c}\text { W } \\
\text { physical }\end{array}$ & $\begin{array}{l}\text { Profit \& loss account: } \\
\text { OTC+futures+physical=P }\end{array}$ \\
\hline \multicolumn{5}{|l|}{ March } \\
\hline Projected sums & Buy x@400 & & Sell y@ 1000 & $(400)+1000=\mathbf{6 0 0}$ \\
\hline Actual contracts & Buyx@400 & Sell x@400 & Sell y@floating & \\
\hline \multicolumn{5}{|l|}{ December } \\
\hline Scenario A prices (level) & & 400 & 1000 & \\
\hline Actual contracts & (Bought x@400) & Buy x@400 & Receive y@1000 & $(400)+$ nil $+1000=\mathbf{6 0 0}$ \\
\hline Scenario B prices (down) & & 200 & 800 & \\
\hline Actual contracts & (Bought x@400) & Buy x@200 & Receive y@800 & $(400)+200+800=\mathbf{6 0 0}$ \\
\hline Scenario C prices (up) & & 600 & 1200 & \\
\hline Actual contracts & (Bought x@400) & Buy x@600 & Receive y@1200 & $(400)-200+1200=\mathbf{6 0 0}$ \\
\hline
\end{tabular}

Source: Author

\section{Risk management of portfolio}

Risk management is the term used to express the continual assessment of all of the components of a business, from price risk of inward and outward goods to counterparty risk to disaster recovery contingencies, to name but some. However, all businesses should take risk management seriously and in the first instance actually assess all of the risks that they are exposed to.

A simple but accurate maxim in English is "don't put all your eggs in one basket" - this is "risk management'. In terms of the gas industry, good risk management of the portfolio would entail, inter alia, buying (selling) a proportion of requirement ahead of time; hedging a percentage of anticipated/actual future commitments; monitoring market conditions; monitoring counterparties and other similar activities.

Remember, to not trade is a trading decision and involves risk in itself!

Another approach to risk managing a portfolio is to have a flexible trading model allowing the possibility to trade with a wide number of counterparties, thereby helping to spread the risk. The business is, after all, about minimising risk and spreading any remaining risk.

Much has been talked in the energy world about "security of supply" and the need for assuring that a particular energy, say gas, will be available to import to satisfy national demand. One way to help minimise this 'risk' is to 'lock in' a percentage of requirement by forward buying, preferably from different sources.

\section{Portfolio optimization}

This notion is one step beyond risk management: it is the continual monitoring of your physical and financial positions, checking whether market conditions have changed or whether company requirements have changed. This should result in limiting exposure whilst maximizing financial returns. In essence, it is about looking for 'added' profit by looking beyond the 'normal' or 'obvious' as there may be other avenues to explore that would result in better profitability. 


\section{Speculation and Profit!}

This last category is unashamedly all about making money from trading: it is about profit! In any successful market there is an element of speculation, which in turn provides the extra liquidity on which trading thrives. The proprietary traders - those who solely trade their own funds for speculation - are an important category in any market and, at the NBP, help to provide this extra liquidity. There are hedge funds, banks, institutional investors, commodity traders and even 'locals' (private individuals 'betting' on the price moves) all speculatively trading in the British gas market. But the liquidity they offer helps in turn the 'traditional' participants by keeping tight bid-offer spreads and plentiful volume to enable those 'physical' players to actually conclude the trades they seek to do.

\subsection{Routes to Market}

The reason for trading will determine which route to follow: through the regulated or non-regulated markets; through the "paper" market or the physical market; using a bilateral contract or a cleared contract. The instruments of trading vary from the bilaterally negotiated traded contracts to the OTC standardised physical deals; from the futures market and other cleared transactions to financial trades such as swaps; finally there is the chance of trading options, either cleared or bilateral, physical or financial.

Figure 4: Routes to market.

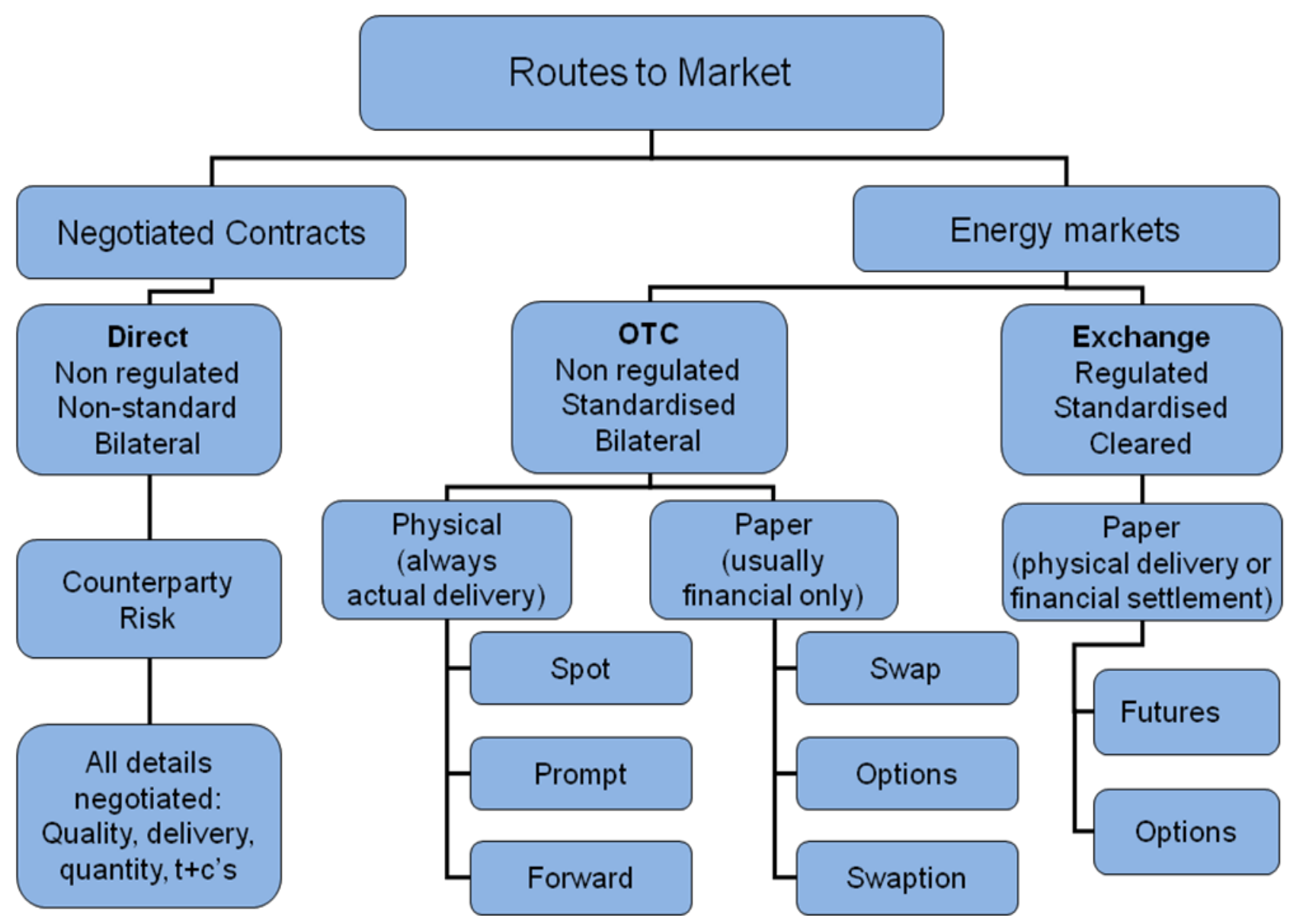

"t+c's" = terms and conditions

Source: Author

\section{Direct Bilateral Contracts}

Bilaterally negotiated contracts as typically traded in the "old world" are individually negotiated contracts on non-standard terms with many variations. Every aspect of each contract will need to be negotiated: quality, location, quantity, volume and all relevant terms and conditions. Because of their 
bespoke nature, these contracts will necessitate a one-to-one legal and credit framework between the seller and the buyer. Some are still traded today, primarily large volume trades, although they are very often on more standardised terms than before and easily cover a medium- to long-term delivery period. They will invariably be traded over the phone for small deals or be negotiated over many months for the long term contracts involving large quantities over a long delivery period.

\section{Over-the-counter Trades}

Over-the-counter (OTC) trades constitute the most common form of trading today. These are still bilateral traded contracts but very importantly are standardised physical deals based on the NBP '97 contract as described above. As well as this contract giving traders a known basis for trading, the OTC market has also evolved in a standardised way in which trades are conducted in 'clips' or multiples of 25,000 therms per day in one of several clearly defined time periods (as detailed below in "method of trading"). This allows for ease of trading, greater transparency and inevitably greater liquidity, and form the backbone of the brokered market today. These deals can be traded over the phone, or more commonly nowadays, by electronic media. Despite the standardisation of these contracts and their popularity, it must be remembered that these are still bilateral contracts and therefore still hold counterparty credit and performance risk. Almost all of the trades are for gas delivery at the NBP, although a few are still transacted at the Entry Points.

\section{Financial (Paper) Trades}

Financial trades have a minority portion of the NBP market, according to one broker less than 5\% over the Winter'09 period, although the recent increase in the number of banks participating in the British market (see Main Participants above) has meant a renewed acceptance of these products. Financial swaps are a mirror of the physical trade, but without physical delivery, using an index at maturity to work out the payment due by one party to the other, of the precise difference between the contract price and the reference out-turn price.

\section{Options}

Options, despite being widely used in other markets, have not attracted much interest in the British gas market. Optionality used to be "given away" in many of the older long-term contracts which included very flexible take-or-pay, swing and re-nomination rights that were included to help "move the gas". In 2010 there are less than five active players in the options market, all of whom are banks, funds and proprietary trader categories. Options are therefore not an integral part of the market.

\section{Exchange Futures and Cleared Trades}

The last route to market involves futures and cleared trades. These are regulated markets where traders are secure in the knowledge that these markets are governed by the Financial Services Authority (FSA) ${ }^{39}$ Trading is anonymous at all times, with a clearing house being the central counterparty to all trades; it is the clearing that also financially guarantees all of the trades executed. These contracts can allow for physical delivery although in practice, only a very small percentage of trades go through to actual physical delivery. For British gas, the futures market is operated by the InterContinental Exchange's European division, ICE Futures Europe (ICE), which is the exchange, and the clearing is provided by another subsidiary, ICE Clear Europe.

\footnotetext{
${ }^{39}$ In 2010 it was announced that the FSA would be abolished and its functions transferred to other bodies; as yet there is no information about these successor institutions.
} 


\section{Figure 5: Contractual relationship when trading futures contracts}

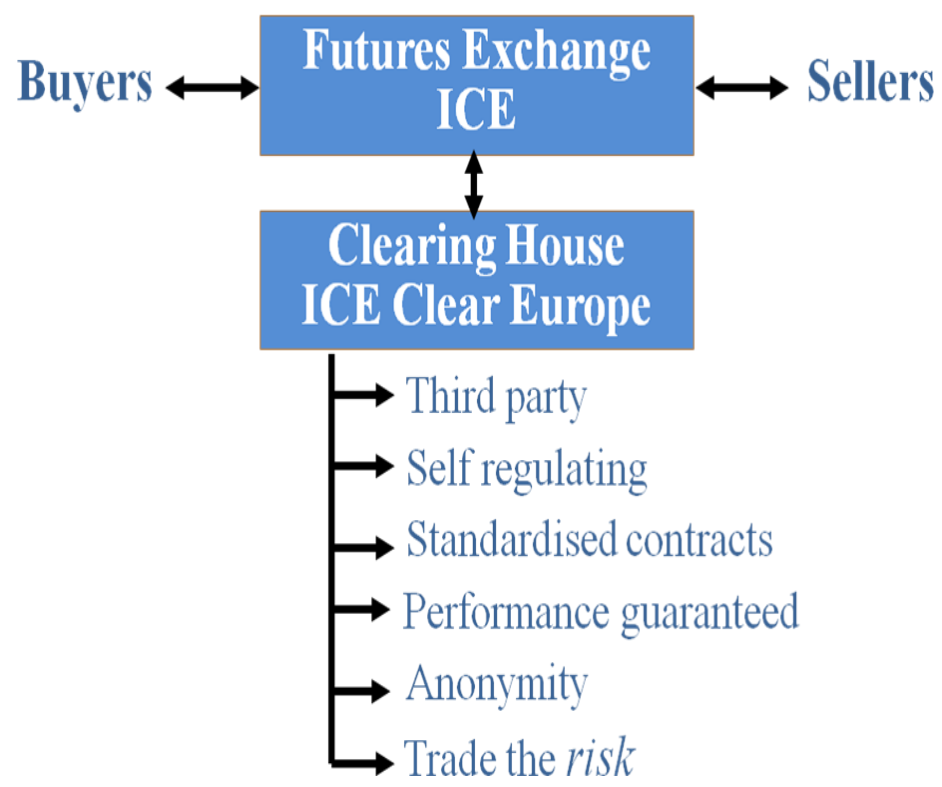

Source: Author

\section{ICE Futures Contract}

The ICE natural gas futures contract is based on physical delivery of gas at the NBP and was launched in January $1997 .^{40}$ It quickly gained acceptance by traders and reached an average market penetration of about $10 \%$, and has remained at around this level until 2008 when, due to the economic recession and the need for greater financial security, more business started being transacted on the Exchange. During the winter 2009/10, the relative share of the NBP futures contract to the overall traded volumes of gas at the NBP reached record levels of around $30 \%{ }^{41}$

The exchange publishes a Month Ahead index which is commonly used to settle financial swaps and in indexed physical contracts. ${ }^{42}$ The ICE contract is used primarily as a hedging tool to manage price risk and as an investment vehicle, allowing for speculative trades, but also to effect physical transfers of gas, as a small percentage does still go to delivery. Participants wishing to reduce counterparty credit risk can do so by "giving up" OTC trades for clearing, in a process known as EFPs (Exchange of Financial for Physical).

As NBP is a benchmark for physical gas in Britain, so too is the ICE contract. Virtually all British gas is traded at the NBP and more and more is traded against the ICE Month Ahead index. A lot of Continental gas is also priced with reference to the NBP price, either OTC or ICE futures.

\footnotetext{
${ }^{40}$ The full ICE contract specification can be seen in Appendix $\boldsymbol{D}$.

${ }^{41}$ Source: calculated by author from various market data: ICE, ICIS-Heren, Spectron, ICAP.

${ }^{42}$ A 'snapshot' taken from the ICE website on $24^{\text {th }}$ March 2010 can be seen in Table 10/Figure 6.
} 
Table 10: Extract from ICE website $24^{\text {th }}$ March, 2010

\section{Natural Gas Index (NATGASINDEX)}

open methodology NATURAL GAS INDEX (NGINDEX)

The final Index is calculated at close of trading on the calendar day that the front month contract expires (that is the last but one business day of each month). The final Index represents the un-weighted average of all settlement prices from the expiring 'front month' contract and is published to the ICE Website.

close

\begin{tabular}{|c|c|c|c|}
\hline \multicolumn{4}{|l|}{ EXPIRY } \\
\hline Expiring Contract & Expiry Date & Published On & Index Price \\
\hline Mar10 & February 25, 2010 & February 25,2010 & 34.657 \\
\hline \multicolumn{4}{|c|}{ NATURAL GAS INDEX } \\
\hline Date & Price & & \\
\hline March 24, 2010 & 30.029 & & \\
\hline March 23, 2010 & 30.040 & & \\
\hline March 22, 2010 & 30.047 & & \\
\hline March 19, 2010 & 30.091 & & \\
\hline March 18, 2010 & 30.188 & & \\
\hline March 17, 2010 & 30.303 & & \\
\hline $\begin{array}{l}\text { Note: all prices in per } \\
\text { therm }\end{array}$ & & & \\
\hline
\end{tabular}

Figure 6: ICE Natural gas index October 2008-April 2010

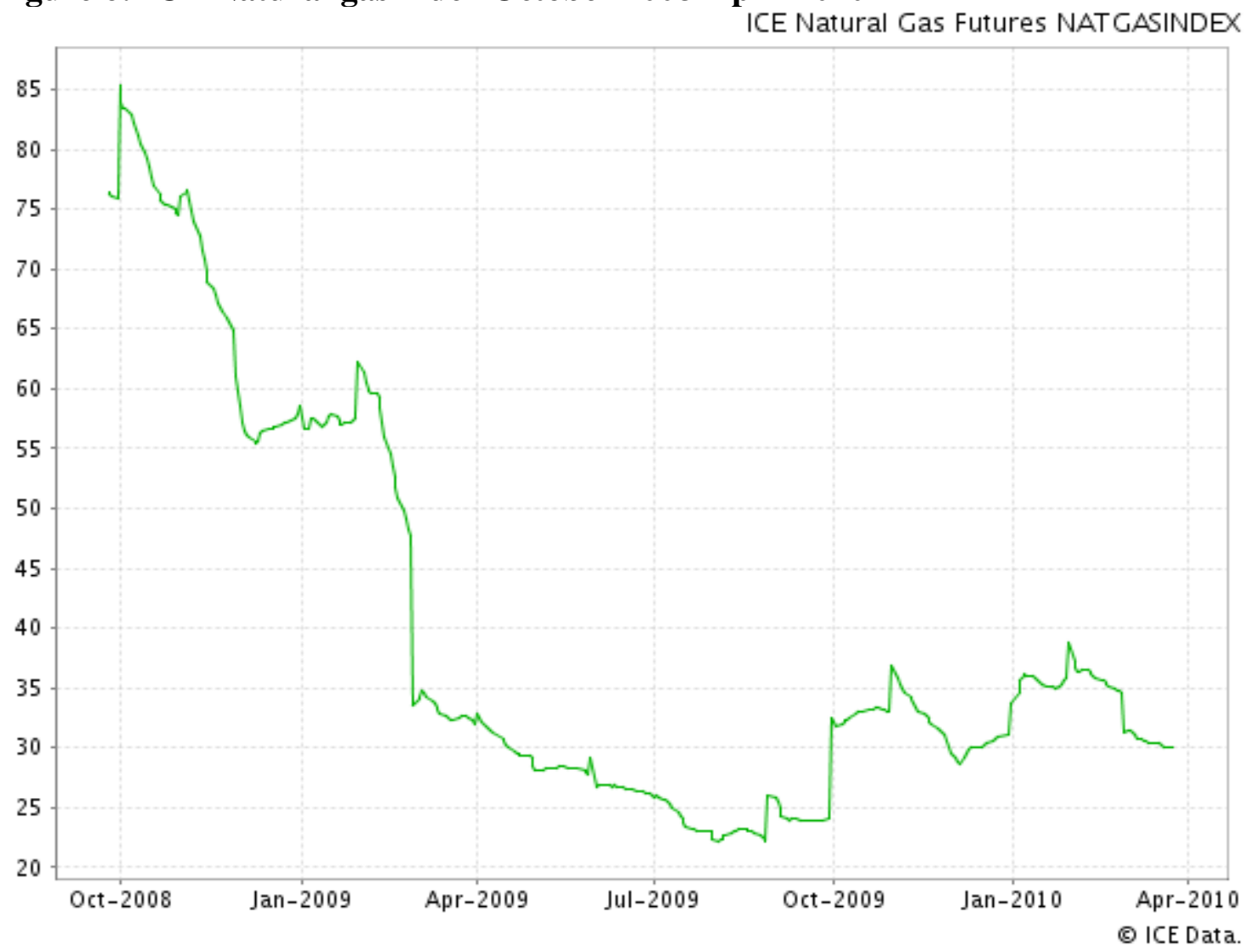

Note: note that prices on the $y$ axis are in pence per therm 


\subsection{Method of Trading}

The method of trade used to participate in the British gas market can be either direct or via brokers, voice or electronic. At the beginning of the liberalised market in 1996, all counterparties used to talk to each other, but today trades are enacted primarily via brokers. Here too the trend has gone from "talking the deal" to "hiding behind a screen"! Today's young traders feel more comfortable clicking a mouse than talking on the phone. All the brokers have their own trading platforms and the ICE futures contract is also traded electronically. There are currently no proprietary screens (owned and operated by a market participant) although in the late 1990s following the success of Enron's trading screen (Enron OnLine), Dynegy also created its own trading platform; however, this was short-lived as Dynegy suffered from its own trading problems and the screen was withdrawn. Finally, the OCM is also screen-based (on the APX platform).

The length of time forward that it is possible to trade is known as the 'curve'. This traded curve covers the spot, the prompt, the near, mid and far curves:

- Spot refers to today or tomorrow;

- Prompt refers to all other periods within the month and the next month;

- The near curve covers the first two seasons; $;^{43}$

- The mid curve covers out to about two years forward;

- The far curve is everything beyond that, currently up to about five years forward, although it is possible to get quotes as far out as 10 years.

The spot and prompt contracts cover days or groups of days such as Within Day (WD), Day Ahead (DA), Balance of Week (BOW), Weekend (WE), Balance of Month (BOM) and the Month Ahead (MA) contract, also known as the first or front month. The curve trades in months, quarters, seasons and years (both calendar and gas year).

\subsection{Trading Activity}

The usual reason for trading in the spot and prompt contracts is to physically optimise or balance a portfolio at, or just ahead of, delivery. The curve is usually used to financially optimise a trading portfolio for hedging or speculative purposes. Most trading activity takes place in the prompt and near curve, with the most popular contracts being WD, DA, MA and the front two seasons. There is activity too in the mid-curve, especially because of spreads between seasons, although beyond three years activity is far less, primarily for credit reasons. It is difficult to get an accurate breakdown of volume along the curve, but about $70-80 \%$ is traded in spot, prompt and near curve, with the remaining $20-30 \%$ in the mid and far curve.

\subsection{Contractual Documentation}

Setting up to trade effectively and safely is a long and rigorous process, involving many hours of legal time. Documentation is needed to cover: credit and performance risk, counterparty contracts, and financial guarantee agreements.

The OTC market, in which trades are contractually bilateral, is not regulated and therefore there is counterparty risk which needs to be mitigated. There is a whole raft of legal documentation used by the industry to mitigate the risk, including master agreements, netting agreements (for volume and payment) and credit limits. Very tight and precise contractual terms are negotiated between parties for each commodity they are proposing to trade, as well as credit agreements to cover financial risk, including Parent Company Guarantees, Letters of Credit and Bank Guarantees.

${ }^{43}$ In gas trading there are two 6 month seasons: Winter starting $1^{\text {st }}$ October and Summer starting $1^{\text {st }}$ April. 
Bilateral master agreements are the over-riding agreements between two companies covering all aspects of mutual trading and credit exposure, as well as the physical and financial settlement of trades. Several industry standard contracts are used for different commodities.

As mentioned above, the NBP'97 is the British gas contract, and in order to trade gas in Britain, counterparties must warrant that they have signed up to the Network Code. The "ZBT 2000" is the contract covering trades at the Zeebrugge hub in Belgium; this was agreed by the industry after the opening of the IUK pipe linking the NTS to the Belgian gas grid to facilitate trading between the two hubs. It is also quite a 'simple' contract although there is a big difference with the NBP'97 in that trades are not kept whole and there is Force Majeure.

The EFET $^{44}$ contract is used for Continental European trades, including the Dutch TTF and French PEGs and German EGT, etc.; due to the varying regimes between each of these countries and the different nature of the gas grids and the participants trading within them, the EFET is a more complex contract than NBP'97 or ZBT 2000.

Other contracts and agreements include the ISDA (International Securities and Derivatives Association), which is a worldwide document covering all financial trades. This is a very comprehensive document which will invariably take a long time to agree between counterparties but can be used for a variety of commodities and encompasses netting and banking agreements as well as product trading. Broker agreements cover their broking services and screen trading (for OTC brokers) and clearing and/or execution of trades (for futures brokers).

\subsection{Market Transparency}

Market transparency is a very important element in market liquidity. Price reporting for NBP trades and their volumes occurs in many ways. Real time information is available on the ICE and broker screens, on Reuters, Bloomberg, and other wire services. Historic reporting is covered in the trade press (ICISHeren, Argus, Platts) and to a limited extent in the national press. There is therefore very good price discovery, transparency and reporting in the UK market. Off-shore production is subject to different rules and regulations (DECC rather than Ofgem), and there is not quite as much information publicly available regarding gas flows or production 'problems'. This has led over the years to calls from nonproducers that more upstream information should be made available, but this is yet to materialise. As well as the Month Ahead Index published by the ICE, a variety of indices are published by ICIS-Heren and Spectron.

\section{Price Drivers}

In this final section we will look at the three types of contracts that have been used in the British gas market, the indexation used in the various physical contracts, the effect of the 2008 economic recession, the role of LNG and its impact on gas prices and finally, a look at the trading drivers in both Britain and Continental Europe.

\subsection{Bilateral Contracts and Their Indexation}

It is important to note that the contracts described here were, and still are, constructed very differently from those used in Continental Europe. I have divided the way in which gas has been traded on long term contracts in Britain into three main categories:

\footnotetext{
${ }^{44}$ European Federation of Energy Traders
} 


\section{Pre-1990 gas contracts}

These refer to the so-called legacy contracts entered into by British Gas and which were bilateral, negotiated deals with upstream suppliers. These were depletion contracts ${ }^{45}$ of usually 25 years or more, with a high take-or-pay percentage $(85 \%)$ and with a fixed price, indexed to a basket of heavy fuel oil and gas oil, or alternatively, a basket of fuel oil, gasoil, inflation and electricity. Unlike the major long term supply contracts signed at that time in Continental Europe, the UK legacy contracts did not have any price re-openers but locked in both parties to the deal once signed.

- These contracts often contained 2 formulae, with the one resulting in the lower price prevailing, for instance:

○ $\mathrm{P} 1=30 \%$ PPI $+20 \%$ electricity $+25 \%$ gas oil $+25 \%$ fuel oil

$\circ \mathrm{P} 2=50 \%$ gas oil $+50 \%$ fuel oil

\section{Post 1990 long term contracts}

These were signed following the "dash for gas" of the power generators needing to supply their new fleet of CCGTs. These too were bilateral negotiated deals to supply gas over a term, commonly 15 years. They invariably had very high take-or-pay levels (95\%) with fixed prices indexed to inflation, gas oil, electricity and coal. Rather surprisingly, as these contracts were primarily signed in order to satisfy the requirements of the banks financing the building of the new power plants, these contracts also did not include price or volume re-openers.

- These contracts had just one, more complex, formula:

$\circ \mathrm{P} 1=50 \%$ PPI $+20 \%$ gas oil $+15 \%$ electricity $+15 \%$ coal

\section{Post 2000 contracts}

These have been largely motivated by security of supply needs and therefore concentrate on securing volume rather than securing price. These are still bilateral, negotiated deals but are now conducted within the competitive market framework that exists in Britain, with associated gas often delivered at the NBP on a "flat" basis and with limited force majeure on both parties, even in the event of upstream problems. Those supply contracts which are in the public domain, are of 8-10 years' duration and the price is invariably indexed to the NBP. However, as all these contracts are of a bilateral nature, there is little information as to how many are in existence and their contractual details.

- In these contracts, the term price is typically indexed to the monthly average of the daily Day Ahead or Month Ahead published prices (usually ICIS-Heren/Spectron or ICE).

The indexation used in these three types of contracts varies from rather complex price clauses in the legacy or "old" long term contracts to a much simpler structure in the more recent term contracts. As the 'Pre-1990' and 'Post 1990' contracts did not have price re-openers, this led to extremely difficult contract renegotiations in the late $1990 \mathrm{~s}$ as, in particular, buyers sought to realign their long term contracts with the much lower wholesale price of gas that prevailed at that time. LNG contracts in the Atlantic Basin, which used to always be referenced to the North American Henry Hub contract will now often be priced against NBP if delivered to the UK or North West Europe.

\subsection{The effect of the 2008 recession}

2008 saw the onset of the global economic recession, which caused a sharp downturn in gas demand. However, trading at the NBP has remained stable, although the mix between OTC and Exchange contracts has shifted slightly, with the regulated futures contracts increasing their share of the overall

\footnotetext{
${ }^{45}$ Depletion contracts refer to those contracts signed by British Gas with the producers, on a field by field, sometimes well by well, basis that allowed for all the gas from that specific production point to be bought by British Gas under the terms of each contract; this is very different to 'general supply' contracts.
} 
volume traded. However, total trading volumes have also increased and so too has the number of market participants, as LNG becomes a major part of the supply mix.

As the world's principal economies slowly pull out of the recession and start the 2010 s with renewed hopes of growth, it is clear that the 12-18 months of recession did cause a discontinuity in the rising trend for gas demand and may also have had significant price impacts. Over the Winter'09 period, following the marked fall in gas demand along with a fall in wholesale spot prices, the major European buyers started a process of renegotiation of the Long Term Contracts (LTCs) with their suppliers. The result was that most of the European LTCs were in part re-negotiated with the Russian and Norwegian suppliers, converting a percentage (press reports stated 10-15\%) of the volume from indexation pricing to spot pricing in exchange for removing the flexibility on that volume, turning it into 'flat' gas.

\subsection{The Role of $L N G$}

LNG is rapidly moving from a marginal source of supply to being a fundamental part of the supply portfolio mix, in the UK, in the Atlantic Basin and indeed globally. The Atlantic Basin has, in the second half of the 2000s, seen the fastest growth in LNG demand, although the Asia-Pacific region is growing rapidly, especially in new markets such as China and India. Both liquefaction and regasification capacity worldwide is increasing significantly and will, by the end of 2010 reach $373 \mathrm{Bcm}$ and $813 \mathrm{Bcm}$ respectively. Figure 7 illustrates that regasification capacity has rapidly outpaced liquefaction.

\section{Figure 7: Liquefaction and regasification capacity - existing, under construction and planned}

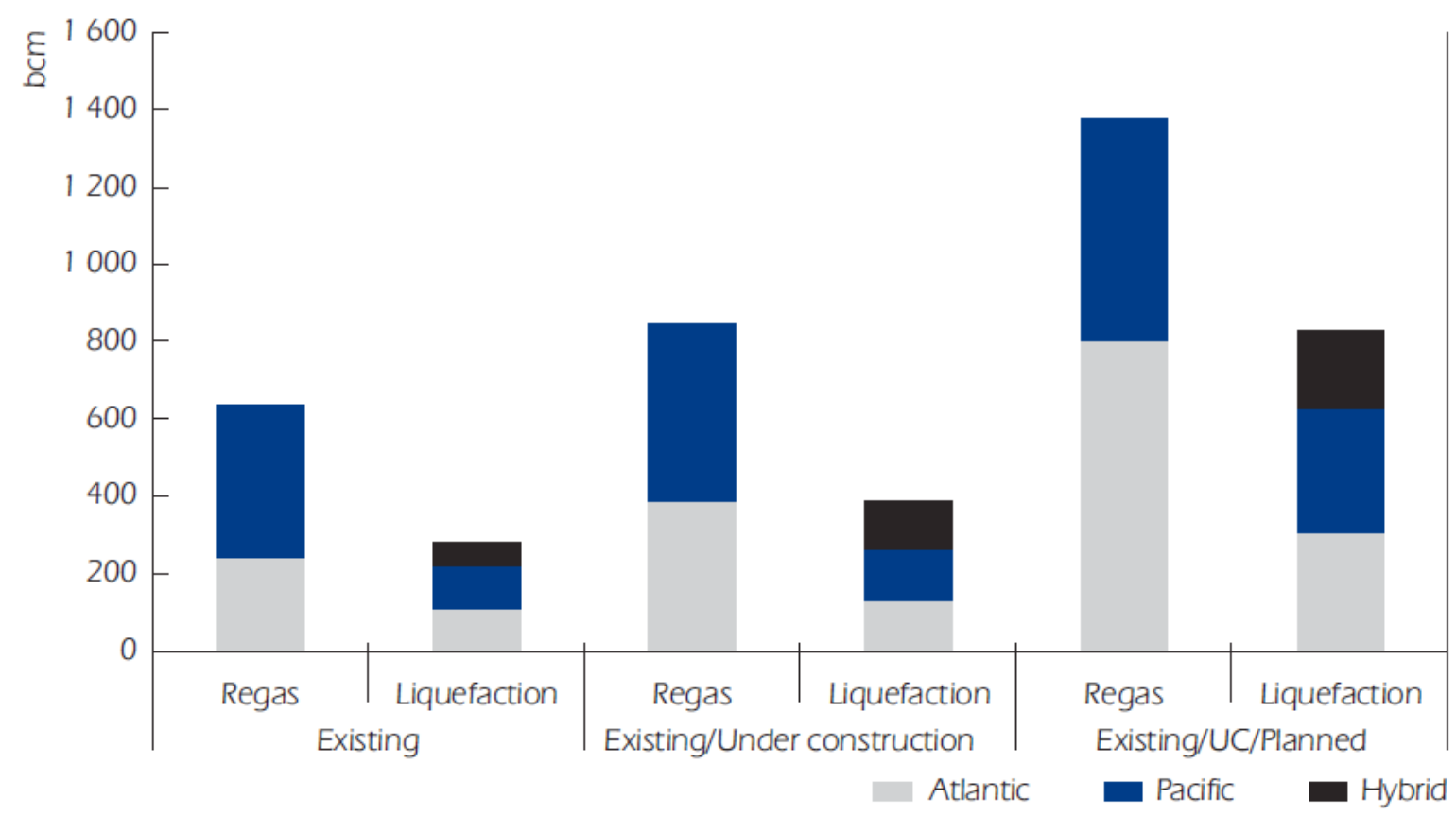

Source: IEA 2009 Natural Gas Review pp.99-100

However it is important to remember that capacity does not equal supply, although having a high LNG import capacity does open up the British market to global arbitrage. The extent of the impact of LNG on UK supply will largely depend on price!

Through LNG, the UK is now becoming part of the global arbitrage for the marginal supply. The development of LNG import infrastructure and the highly developed British gas transmission system with its pipeline connections to Continental Europe and Ireland mean that, given the right price signals, the UK should attract LNG cargoes, either for its own demand or to transit through its system for 
onward sale. Indeed, with the recent development of LNG re-exported from the Zeebrugge terminal, ${ }^{46}$ we could see the large volume of tankage at Milford Haven being used as an LNG 'hub', for redistribution across North West Europe, or even across the Atlantic Basin.

\subsection{Trading drivers - UK}

The traded gas market in Britain is driven in the prompt by weather and operational factors which can therefore lead to quite volatile prices. The forward (next) winter is driven by supply and demand perceptions. The forward summer is driven more by storage arbitrage, and the rest of the forward curve is driven either by supply perceptions and new infrastructure projects, including LNG projects or by partial linkage to the forward Brent crude oil curve and other energy price curves.

\subsection{Trading drivers - Continent}

Unlike in Britain, the Continental gas market is fairly insensitive to short term supply and demand, as it is mainly supplied by long term contracts. European gas merchants use the spot markets at Zeebrugge and the NBP to help balance their day-to-day portfolios, but also as a source of cheap gas to fill their storage. There are long term contracts which are indexed to oil prices and are adjusted quarterly in arrears but do contain re-opener clauses and it is possible to include other indexation elements if both parties were to agree that oil products are no longer appropriate. The key trading driver here is optimisation within the long term contract take-or-pay limits. However, with the LTC changes as described in "the effect of the 2008 recession" above, it is clear that the trading drivers are slowly but surely changing as we enter this new decade.

\section{From the 2000's to the 2010's and beyond...}

\subsection{Commercial prospects for the UK gas market}

LNG is truly becoming a global market, gradually moving away from the early days of 'point to point' destination contracts with little or no flexibility. The events of the past few years have all contributed to 'opening up' the LNG world:

- crude prices rising to a record high of $\$ 147 /$ barrel in the summer of 2008 , rapidly falling back down to $\$ 37$ in December 2008, before rallying again to the current levels around $\$ 80$ (Q12010);

- volatile gas prices;

- pipeline gas supplies suffering from disruptions;

- the Japanese nuclear outage creating an urgent 'spot' need to buy LNG.

However, possibly the greatest factor in changing the attitudes towards the commercialisation of LNG is that the supply is increasing at a very rapid rate.

The LNG world is primarily divided into three major demand zones: Far East, Europe and North America. Because of the lack of interconnectivity between Spain and the rest of Europe, and the fact that it is a major importer of LNG, Spain could be considered as a fourth demand area in its own right. ${ }^{47}$

\footnotetext{
${ }^{46}$ Since mid-2008 there have been reports of at least 10 LNG cargoes re-exported from Zeebrugge; further information can be read at: http://www.icisheren.com including:

"Distrigas sells third reloaded Zeebrugge LNG cargo for Far East delivery" ESGM 30SEP2008

"EDF reloads Zee cargo for freezing China market" ESGM 26NOV2009

"Vitol signs string deal with Kuwait's KPC" ESGM 27APR2010

47 'LNG Trade-flows in the Atlantic Basin, Trends and Discontinuities', Howard Rogers, OIES, 2010
} 
Situated in the north west of Europe, the UK has the trading capability and is well placed geographically to be a major LNG import hub, using the pipeline connections for onward distribution into Ireland and Continental Europe. Regasification capacity in operation and under construction (see Table 4) means that it could become the world's $5^{\text {th }}$ largest LNG importer behind Japan, the US, South Korea and Spain. $^{48}$

Pipeline infrastructure in and around the UK will increasingly perform a dual role, as a means of direct supply of gas from producer to consumer, for which it was originally designed, but also facilitating the 'redirection' of gas volumes from one demand area to another. Indeed, with the building of the new pipeline connecting Milford Haven to the NTS, there is now a robust, high capacity cross-country link to the Bacton terminal in eastern England and, by way of the Interconnector, to Europe.

This brings us back to the possibility of a gas trading 'hub' centred on Britain. In their search for new trading products (and in order to help the industry balance out peaks and troughs in physical gas flows), this could provide a new growth area for NBP gas traders, who have proved themselves adept at embracing new ideas in the past. The British gas market is already the most liquid and transparent traded gas market in Europe, with clearly defined standardised contracts. This could encourage European importers of gas to do so through the UK, as a counterpoint to the major pipeline imports from Norway and from Russia.

Already, Zeebrugge is traded in pence/therm and its price is mostly aligned to that at the NBP. Although traded in Eurocents/MWh, the TTF market is also closely in line with UK prices. Even the German NCG traded market follows by and large the British market.

Despite the German, Dutch and Belgian markets being heavily influenced by oil prices due to the indexation of their Long Term Contracts (LTC) to oil products, there is still a strong correlation between the NBP price (in green) and the other three markets which are themselves strongly correlated. This does make sense because the trades done on the German NCG are simply marginal 'spot' volumes and reflect the cost of gas at the TTF or at Zeebrugge or indeed at the NBP plus/minus transportation and other delivery costs. NBP, through its open, traded environment, is currently the clear 'trading hub' in North West Europe. Indeed, most LTCs for supply to the UK are being priced against the NBP market and, depending on the relationship between gas and oil prices, there could soon be further pressure to move away from oil pricing in continental Europe too (following the successful outcome of the initial renegotiations done in early 2010, as described in "the effect of the 2008 recession" above).

\footnotetext{
${ }^{48}$ National Grid TYS 2008: p.53 Figure 4.5E
} 
Figure 8: European gas hubs price comparison, Jan 2008-May 2010

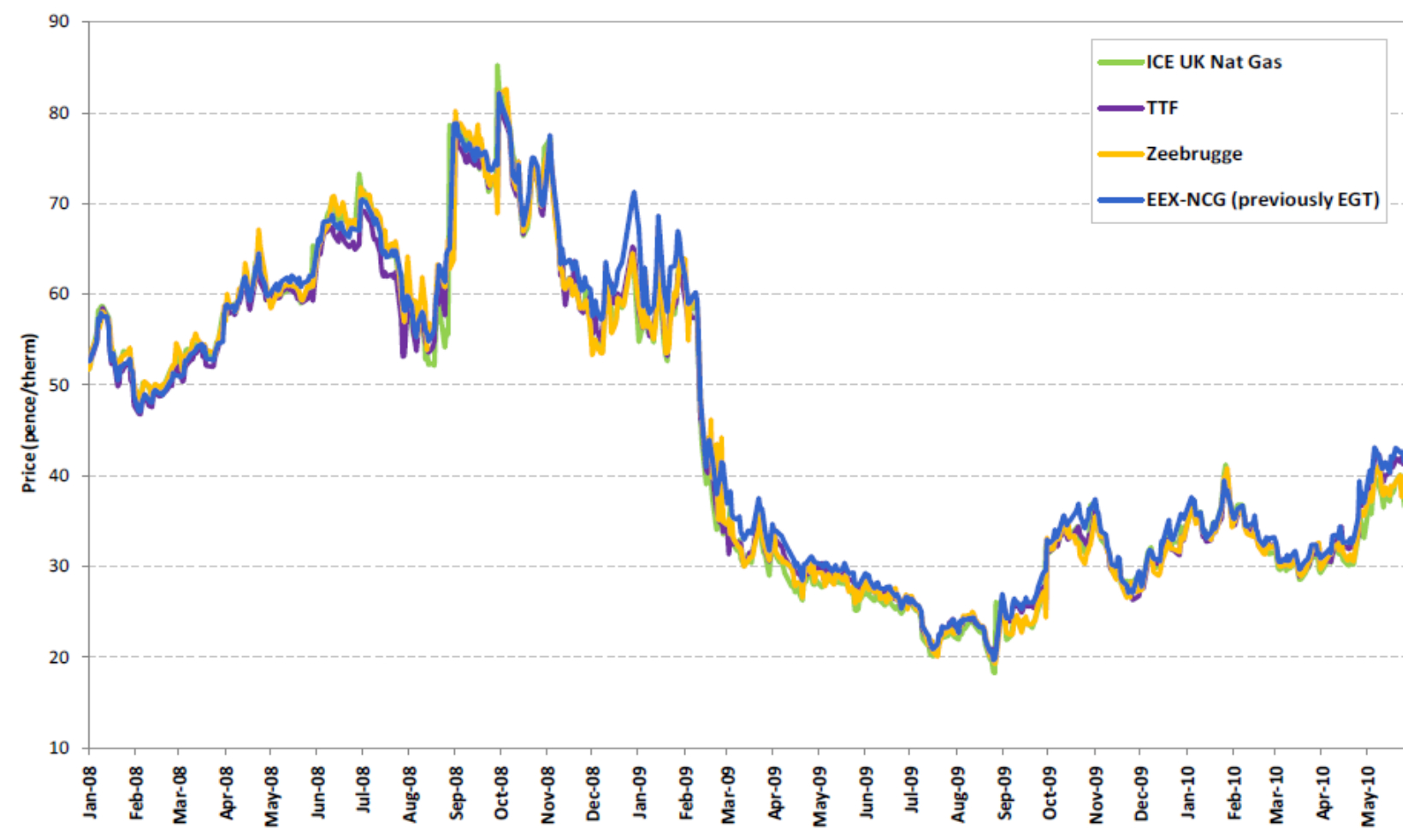

Source: ICE

What could certainly become a reality is some form of 'Channel delivery area' for LNG, where the final destination terminal is declared by the buyer shortly before the arrival of the vessel. In this way the choice of ultimate destination could be partly dealt with in the physical delivery of the LNG before any onward transportation of the gas. Any price variation due to shipping differentials, varying terminal costs or simply market price differentials, would be accounted for in the final invoicing of the cargo. (A similar concept exists in the oil products world with Gasoil contracts delivered to ARA - Amsterdam, Rotterdam, Antwerp). Moreover, this would permit traders and the industry in general, much greater flexibility in the managing of their portfolios.

\section{Summary and Conclusions}

Much has happened since the 'opening' of the British gas market in 1996 and the first tentative trades in the newly-formed liberalised environment. With the rapid acceptance by traders of NBP as the delivery point of choice (eschewing the original 'beach' trades) and the development of the NBP'97 contract to assist them in standardising these OTC trades, the market was ready to welcome new participants and methods of trading. The ICE gas futures market, based on the NBP'97 contract, was quick to establish itself in 1997 and to gain a 10\% market penetration. Enron and other American trading houses brought with them a new approach to trading, not previously experienced in the traditional British gas market, such as quoting tight bid/offer spreads rather than just taking a 'buyer' or a 'seller' position. Brokers and the trade press helped to disseminate information both at the time of trading and in daily reports, which served to create greater transparency and in turn gave confidence to market participants that it was 'safe' to trade NBP gas. 
Trading was on a 'high' in the late 90's with the number of participants increasing almost monthly, volumes growing exponentially and, in addition to the 'traditional' OTC deals, the types of trades included futures, swaps, even a few options. With the opening of the IUK interconnector pipeline to Belgium in 1998, UK traders thought that they were spearheading a European drive which would create a pan-European gas market within next 2-3 years. Of course, some would say that this all happened too quickly and the market had set itself up for a fall. A fall indeed did occur in 2001 with the collapse of Enron and trading turmoil ensued, especially within the American trading houses who did not know whether to try to pick up the pieces or to simply pack up and leave.

In the autumn of 2002, after the near collapse of Eastern Gas Marketing (owned by TXU Europe), gas trading suffered a severe setback. Along with a reduction in the number of participants, traded volumes fell and indeed the focus of trading was very much limited to the spot, prompt and near curve with very little being traded more than one or two seasons ahead. The 'churn rate', which had reached as much as 21 times before the Enron collapse, fell to around 6-7 times, This period lasted about four years, while lawyers and risk managers worked out how to limit their companies' financial exposures while at the same time utilising trading to help optimise their portfolios.

From around 2006-07, gas trading in Britain began to recover and its second wave of development once again began to attract new players including quite a few Continental European companies and an increasing number of financial institutions. 2010 has seen the greatest number of companies trading in the market's 15 year history. Volumes and churn rates increased such that by 2010 they had almost returned to their previous highs. Even the 2008-09 recession seemed to have little overall effect on the market, although it prompted a change in the shares of OTC and Exchange trades, with the regulated futures contracts accounting for nearer $30 \%$ of the total.

From an infrastructure point of view, the past five years have also seen a lot of changes, including additional pipelines to the UK (Langeled and BBL), new LNG receiving terminals, NTS upgrades and a major upgrade to the IUK interconnector pipeline. These mean that the UK ceased to be a gas island and became well connected to the outside world.

While the vision of a pan-European traded market of the late 1990s proved to be premature, Continental European trading hubs did emerge and grow. Since the opening of the IUK interconnector in 1998, Zeebrugge has become an outpost of the NBP on the Continent: trading there is conducted in pence/therm, as at the NBP, rather than in MWh as at the other European hubs. Although Zeebrugge has not developed as a trading hub in its own right, it is an important physical entry point to the North West European gas grid with a major LNG receiving facility.

Title Transfer Facility (TTF), the Dutch gas hub has gained in importance and, in 2010, although still a lot smaller than NBP is the most advanced of the hubs in Europe, in terms of openness, traded volumes and churn rate. Third after Zeebrugge and TTF, and with arguably the most expansion potential, is the Net Connect Germany (NCG) hub. If the plan to merge the gas transport regions in Germany is achieved by 2014 , this hub would then have a similar trading potential to NBP. ${ }^{49}$ Should this become the case, then NCG could become a price marker for German and even North West European gas deliveries in the second half of the 2010s.

Looking forward, I believe that there is enormous potential still in the NBP market as it leads the way towards a more unified North West European gas trading system. Obstacles remain, especially in relation to Third Party Access and the upgrading of border transportation capacities. However, the EU's Third Package of legislation will inevitably lead all countries to develop a daily balancing market which will require both improved access and increased trading.

\footnotetext{
${ }^{49}$ Assuming that NCG rather than the other German hub (GASPOOL) will dominate.
} 
Large scale expansion of LNG import capacity will be a major factor in bringing the North West European hubs together. Increasingly traders will be able to physically move gas between the hubs and therefore will develop cross-market trading instruments to enable them to do this. As liquidity increases, so too will the ability to balance requirements between the various regions.

Since 2008, there has been an increasing debate about the future of oil indexation in the old style long term contracts in Continental Europe, as well as the topic of 'benchmark' hub(s) from which to price gas deliveries of new style European physical contracts (which already exist in the UK). The NBP already has the liquidity and transparency to become a benchmark but this has met with resistance from Continental Europe. If the NCG hub can develop as indicated above, then there is a strong possibility that it could assume the role of benchmarking gas deliveries from the east whilst NBP is used to price gas in the UK and LNG imports. In any event, the pricing of gas at hubs, rather than in relation to oil products, will accelerate trading.

Finally, even in Britain where there is a fully open gas market with a large churn rate, most of the trading is still based on physical delivery, either actual or implied through the contracts used. As Continental European markets open up I believe that there will be a gradual separation of the physical from the financial and that a greater range of financial trading instruments will develop including swaps, based on hub indices, and options. These will become increasingly necessary as more physical gas is transacted on a 'flat' basis.

This paper has focussed on the evolution of traded gas market in Britain, but it has demonstrated that by 2010, gas trading had already expanded to North West Europe, and there is no reason to assume that geographical limits have been reached and that trading will not eventually become a pan-European phenomenon. A key question however, remains whether the British market will continue to dominate European gas trading, or whether activity will move towards the geographical centre of the continent. 


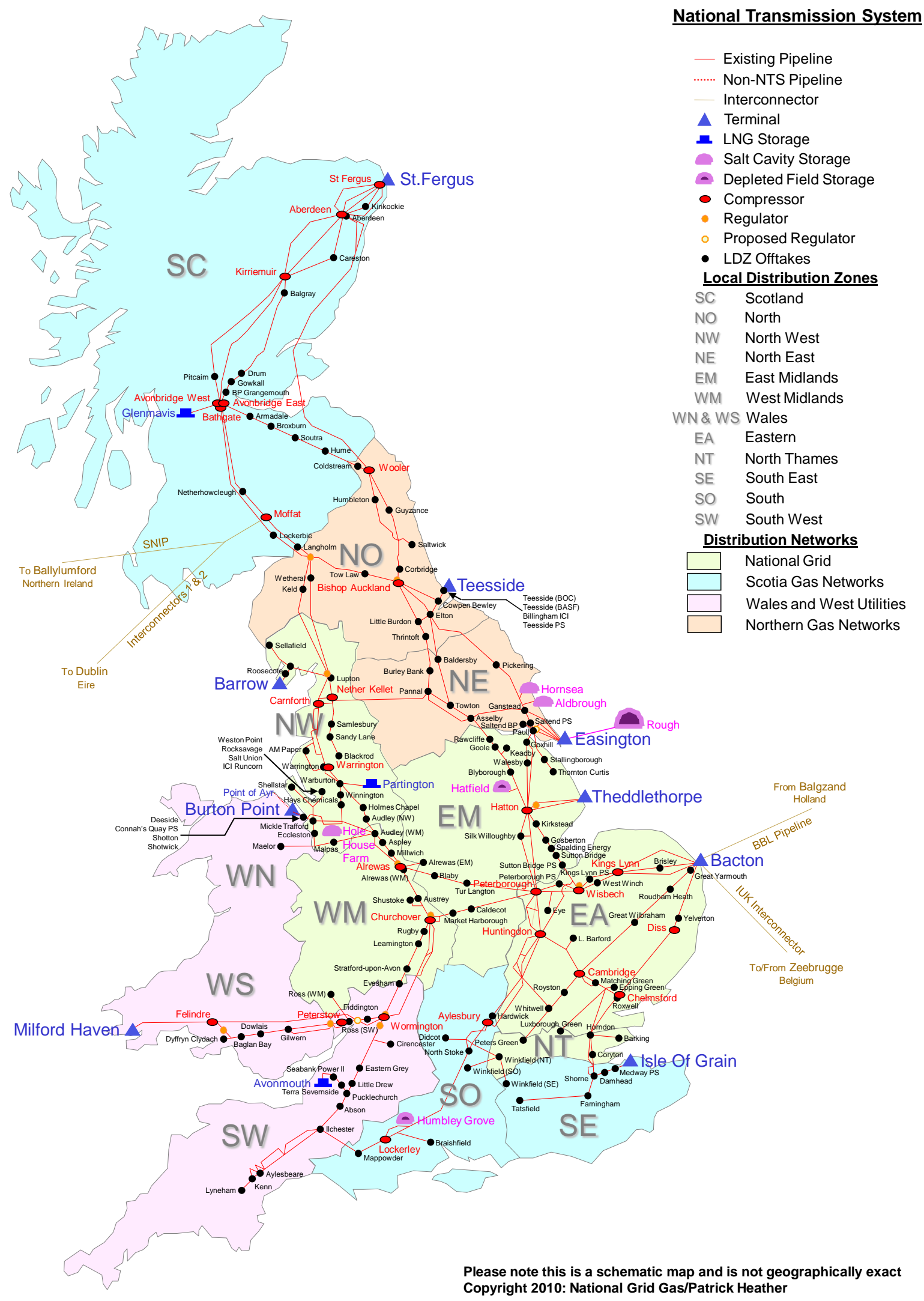

National Transmission System

Existing Pipeline

... Non-NTS Pipeline

rconnecto

LNG Storage

- Salt Cavity Storage

- Depleted Field Storage

- Compressor

NT North Thames

SE South East

so South

W South West

Distribution Networks

Scotia Gas Networks

Wales and West Utilities

Northern Gas Networks 
Appendix B. “NBP'97” specimen contract

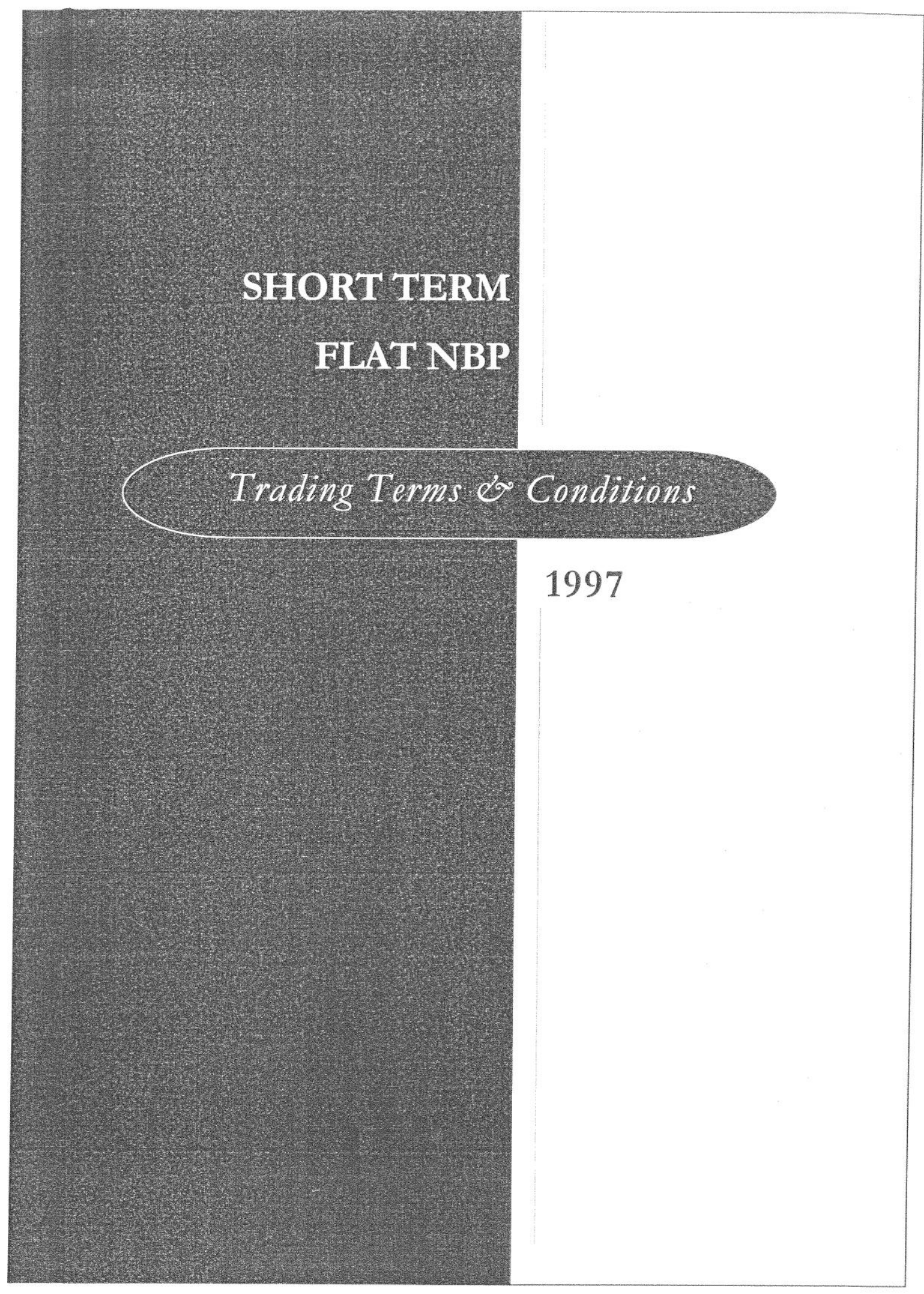


1. Definitions and Interpretation

1.1 The following words or phrases, where they appear in these terms and conditions or in a Confirmation, shall have the meanings respectively ascribed to them:

"Accurate Trade Nomination" shall mean in respect of a Day and a quantity of Gas, a Trade Nomination made by a Party which complies with the Code Credit Limits and Clause 4.1 .3 before 0400 hours on the Day (being in the ca se of the Seller a Disposing Trade Nomination and in the case of the Buyer an Acquiring Trade Nomination) for the Daily Quantity identifying the other Party as the person making the corresponding Trade Nomination;

"Acquiring Trade Nomination" shall have the meaning specified in the Network Code;

"Affiliate" shall mean any holding company or subsidiary company of a Party or any company which is a subsidian company of the holding company of a Party and the expressions "holding company" and "subsidiary" shall have the meanings respectively ascribed to them by section 736 Companies Act 1985;

"Argus Gas Price" shall mean the bid price where the non-defaulting Party is the Buyer or the offer price where the non-defaulting Party is the Seller as published on a Day for the remainder of the Supply Period by Petroleum Argus Lto in Petroleum Argus European Natural Gas;

"Banking Day" shall mean a day (other than a Saturday or a Sunday) on which the clearing banks in London are open for business;

"Buyer" shall mean the Party required to make Acquiring Trade Nominations pursuant to the Transaction;

"Code Contingency" shall have the meaning specified in the Network Code;

"Code Credit Limit" shall have the meaning specified in the Network Code;

"Confirmation" shall mean a document that incorporates these terms and conditions by reference and confirms the details of the Transaction. The Confirmation shall be substantially in the form of the Schedule hereto;

"Contingency Procedures" shall have the meaning specified in the Network Code;

"Contract Price" shall mean the sum agreed as such for the Transaction, exclusive of VAT and other applicable taxes;

"Daily Imbalance" shall have the meaning specified in the Network Code;

"Daily Quantity" shall mean the daily quantity of Gas agreed between the Parties as such for the Transaction;

"Day" shall mean the period beginning at 0600 hours on a day and ending at 0600 hours on the following day;

"Disposing Trade Nomination" shall have the meaning specified in the Network Code;

"Early Termination Payment" shall be an amount payable on termination in accordance with Clauses 10.4, 10.5 and 10.6 ;

"Force Majeure" shall mean any event or circumstance beyond the reasonable control of a Party which totally prevents a Trade Nomination from being submitted by such Party to Transco or from being received and taken into account by Transco in determining such Party's Daily Imbalance;

"Gas" shall have the meaning specified in the Network Code;

"Gas Flow Day" shall have the meaning specified in the Network Code;

"Heren Gas Price" shall mean the bid price where the non-defaulting Party is the Buyer or the offer price where the non-defaulting Party is the Seller as published on a Day for the remainder of the Supply Period by PH Energy Analysis Led. in British Spot Gas Markets;

"IPE" shall mean the International Petroleum Exchange;

"IPE Gas Price" shall mean the IPE settlement price as published by the IPE on that Day for the remainder of the Supply Period; 
"LIBOR" shall mean, in respect of a month, the one month London Interbank Offered Rate (expressed as a percentage per annum) in sterling as notified by National Westminster Bank ple at which a deposit of a principal sum equal to the relevant sum in question under these terms and conditions would have been offered by such bank to prime banks in the London Interbank Market at such banks' request at or about 1100 hours on the first Banking Day in such Month for a period commencing on such Banking Day and ending on the first Banking Day in the next succeeding Month;

"Month" shall mean a period beginning at 0600 hours on the first day of a calendar month and ending at 0600 hours on the first day of the following calendar month;

"Monthly Statement" shall have the meaning specified in Clause 6.1 ;

"NBP Trade" shall mean, in respect of a quantity of Gas, (where:

(a) in respect of any Day two Users make corresponding Trade Nominations in respect of that quancty of Gas subject to and in accordance with Section C6 of the Network Code, and

(b) neither Trade Nomination is amended or withdrawn thereafter), the deduction by Transco of that quantity of Gas in determining for that Day the Daily Imbalance of the User making the Disposing Trade Nomination and the addition by 'Transco of that quantity of Gas in detemining for the same Day the Daily Imbalance of the User making the Acquiring Trade Nomination;

"Network Code" shall mean the document, as modified from time to time, setting out transportation arrangements established by Transco pursuant to its public gas transporter's licence;

"Party" shall mean one or other of the parties to the Transaction;

"Pricing Indices" shall mean the Heren Gas Price and the Argus Gas Price and the IPE Gas Price;

"Seller" shall mean the Party required to make Disposing Trade Nominations pursuant to the Transaction;

"Supply Period" shall mean the period during which, pursuant to the Transaction, the Parties shall make NBP Trades, such period commencing and terminating on the Days agreed for the Transaction;

"System Average Price" shall have the meaning specified in the Network Code;

"System Marginal Buy Price" and "System Marginal Sell Price" shall have the respective meanings specified in the Network Code;

"Therm" shall mean one hundred and five million five hundred and six thousand joules $(105,506,000 \mathrm{~J})$;

"Trade Nomination" shall have the meaning specified in the Network Code;

"Transaction" shall mean an oral or written agreement to undertake one or more NBP Trades such agreement to include, inter alia, these terms and conditions, details of the Supply Period, the Daily Quantity, and the Contract Price;

"Transco" shall mean BG plc or any successor to the BG plc public gas transporter licence;

"UK Link" shall have the meaning specified in the Network Code;

"User" shall have the meaning specified in the Network Code;

"Week" shall mean a period of seven (7) days beginning at 0600 hours on any Sunday and ending at 0600 hours on the following Sunday.

Any reference in these terms and conditions to a Transaction includes any permitted assignment, novation, supplement or amendment thereto.

1.3 Any reference to a Clause or Clauses is a reference to a clause or clauses in these terms and conditions.

1.4 Words in the singular may be interpreted as including the plural, and vice versa

1.5 Any reference in these terms and conditions to a statute or statutory instrument or order is a reference to that statute, statutory instrument or order as from time to time amended, re-enacted or supplemented.

1.6 In the event of conflict between the terms of a Confirmation and these terms and conditions, the terms of the Confirmation shall prevail.

1.7 Any reference in the Transaction to a quantity of Gas shall mean a quantity expressed in Therms.

1.8 Any reference in the Transaction or the Confirmation to time shall be to the time in London 
2.1 The Seller shall, within three (3) Banking Days of a Transaction being entered into, send by facsimile transmission to the Buyer a signed Confirmation recording the details of the Transaction.

2.2 If the Buyer is satisfied that the Confirmation accurately reflects the terms of the Transaction the Buyer shall sign and return the Confirmation by facsimile transmission to the Seller within three (3) Banking Days of receipt of the Confirmation.

2.3 If the Buyer is not so satisfied, the Buyer shall inform the Seller of. any inaccuracies. The Seller shall, if it agrees that the Confirmation is inaccurate, issue a new Confrrmation and the provisions of Clause 2.1 shall apply.

2.4 If the Buyer does not return the Confirmation, duly signed, in accordance with Clause 2.2, or notify the Seller of any inaccuracy in accordance with Clause 2.3 , the Buyer shall be deemed to accept the Confirmation.

2.5 If the Buyer has not received a Confirmation from the Seller within three (3) Banking Days of a Transaction being entered into, the Buyer shall send the Seller a Confirmation, and Clauses 2.2,2.3 and 2.4 shall apply mutatis mutandis in relation to such Confirmation by replacing in such clauses all references to "Buyer" with "Seller" and "Seller" with "Buyer".

26 Subject to Clause 2.4, on signature by both Parties, the Confirmation shall, save in the event of manifest error, prevail over any oral or written agreement in respect of the Transaction.

2.7 The Parties hereby consent to the recording of telephone conversations in respect of the Transaction.

$2.8 \quad$ Failure or persistent failure by the Seller or the Buyer to send a Confirmation shall not be a material breach of the Transaction.

3. Representations and Warranties

Each Party represents and warrants to the other that it has obtained and will maintain at all times during the Supply Period all licences, authorisations, permits, consents and other approvals necessary to enable it to fulfil its obligations under the Transaction and that it is and will remain a party to the Network Code.

\section{NBP Trades}

Trade Nominations

4.1.1 Each Party shall in respect of a Day within the Supply Period for which the Daily Quantity is greater than zero make an Accurate Trade Nomination;

4.1.2 If, on any such Day, UK Link is affected by a Code Contingency and which affects a Party, such Party shall submit its Trade Nomination by the means and in the manner provided for in the Contingency Procedures;

4.1.3 Trade Nominations shall be made in kilowatt hours, for which purpose the conversion from Therms shall be calculated in accordance with the following formula

$K=29.3071 \times \mathrm{T}$ rounded to the nearest kilowatt hour, an exact half being rounded upwards; where "K" is the quantity expressed in kilowatt hours and " $\mathrm{T}$ " is the quantity expressed in Therms.

4.1.4 Where in respect of a Day the Trade Nominations submitted by the Parties pursuant to the Transaction are considered not to be effective and are rejected by Transco in accordance with section $\mathrm{C} 6$ of the Network Code:

(a) a breach by the Buyer shall be deemed to have occurred if the last Accurate Trade Nomination notified to Transco in respect of the Transaction was made by the Seller, and

(b) a breach by the Seller shall be deemed to have occurred if the last Accurate Trade Nomination notified to Transco in respect of the Transaction was made by the Buyer.

4.1.5 Where Transco has accepted an Accurate Trade Nomination, neither Party shall, unless otherwise agreed by the Parties, amend or withdraw such Accurate Trade Nomination;

4.1.6 The Parties shall use their reasonable endeavours to make Accurate Trade Nominations by in the case of the Seller 1300 hours on the Day before the Gas Flow Day and, in the case of the Buyer, by 1600 hours on the Day before the Gas Flow Day.

Save and except in respect of an event of Force Majeure, if for any Day the Seller is in breach of Clauses 4.1.1, 4.1.2 or 4.1.5, the Seller shall pay to the Buyer either 
A. the sum, where positive, of (SMBP-CP) $\times$ DQ where "SMBP" is the System Marginal Buy Price fox that Day, "CP" is the Contract Price, "DQ" is the Daily Quantity; or

B. the sum, where positive, of (SAP-CP) $x$ DQ where "SAP" is the System Average Price for that Day, "CP" is the Contract Price, "DQ" is the Daily ( $u a n t i t y$, unless the Buyer can show that the actual loss suffered in respect of that Day was greater, in which circumstances the Seller shall pay to the Buyer such sum as represents the Buyer's actual loss, such payment to be no greater than the amount calculated in accordance with $4.2 \mathrm{~A}$

The Parties shall specify for the Transaction the basis of compensation payable in the event of a breach.

Payment in accordance with the provisions of this Clause 4.2 shall be in full and final satisfaction of the rights of the Buyer and the sole remedy available to the Buyer in respect of a breach by the Seller of Clause 4.1 howsoever caused and even where caused by the negligence or breach of duty of the Seller except for any other remedies expressly provided in the Transaction.

\section{NBP Trade: breach by the Buyer}

Save and except in respect of an event of Force Majeure, if for any Day the Buyer is in breach of Clauses 4.1.1, 4.1.2 or 4.1 .5 , the Buyer shall pay to the Seller, either:

A. the sum, where positive, of (CP-SMSP) $\times$ DQ where "SMSP" is the System Marginal Sell Price for that Day, "CP" is the Contract Price and "DQ" is the Daily Quantity; or

B. the sum, where positive, of (CP-SAP) x DQ where "SAP" is the System Average Price for that Day, "CP" is the Contract Price, "DQ" is the Daily Quantity, unless the Seller can show that the actual loss suffer ed in respect of that Day was greater, in which circumstances the Buyer shall pay to the Seller such sum as represents the Seller's actual loss, such payment to be no greater than the amount calculated in accordance with $4.3 \mathrm{~A}$.

The Parties shall specify for the Transaction the basis of compensation payable in the event of a breach.

Payment in accordance with the provisions of this Clause 4.3 shall be in full and final satisfaction of the rights of the Seller and the sole remedy available to the Seller in: respect of a breach by the Buyer of Clause 4.1 howsoever caused and even where caused by the negligence or breach of duty of the Buyer except for any other remedies expressly provided in the Transaction.

\section{Payment of Compensation}

Any amount due under either:

(a) Clauses $4.2 \mathrm{~A}$ or $4.3 \mathrm{~A}$; or

(b) Clauses $4.2 \mathrm{~B}$ or $4.3 \mathrm{~B}$ where the amount for the purpose of this Clause 4.4 shall be on the basis of SAP, unless the Seller under Clause $4.2 \mathrm{~B}$ or the Buyer under clause $4.3 \mathrm{~B}$ has agreed in writing to a greater level of actual loss;

may, at the election of the non-breaching Party, be set-off against amounts due or becoming due under Clause 6 :

\section{The Contract Price}

In respect of a Transaction:

5.1 the Buyer shall pay the Seller in arrears for each NBP Trade a sum calculated by multiplying the Contract Price by the Daily Quantity;

5.2 the Buyer shall pay any VAT in relation to each NBP Trade on receipt of appropriate tax invoices from the Seller and shall ensure that all royalties, taxes, duties and other sums legally payable by the Buyer arising as a result of each NBP Trade are paid;

5.3 the Seller shall ensure that all royalties, taxes, duties and other sums legally payable by the Seller arising as a result of each NBP Trade are paid.

\section{Billing and Payment}

6.1 On or before the tenth (10th) day of the Month following each Month which is wholly or partly in the Supply Period the Seller shall send to the Buyer a statement ("Monthly Statement") which shall show for the preceding Month:

6.1.1 the quantity of Gas in respect of which NBP Trades have been effected on each Day in that Month; 
6.1.3 the Contract Price;

6.1.4 any amount owing from one Party to the other or already paid or set-off under Clause 4.4 or 6.7 ;

6.1.5 the net amount payable from one Party to the other after taking into account all the matters set out above, and

6.1.6 VAT and any other applicable taxes.

On the twentieth (20th) day of the Month in which the Monthly Statement is received by the Buyer or the tenth (10th) day after receipt, whichever is the later ("the due date"), the Buyer or the Seller, as the case may be, shall pay to the other Party the net amount payable in accordance with the Monthly Statement.

Payment shall be made by the due date in sterling by direct bank transfer or equivalent transfer of immediately available funds to the Party to whom it is due and to the credit of the account specified by that Party.

6.4 If the due date for payment is not a Banking Day then payment shall be made on the previous Banking Day.

If a Party disputes any sum shown in the Monthly Statement as being payable by that Party, it shall make payment of any undisputed amount on or before the due date for payment and shall give notice of the amount in dispute and the reasons therefor to the other Party. The Parties shall seek to settle the disputed amount as soon as possible.

If a Party fails to pay to the other Party by the due date for payment any amount due:

6.6.1 interest shall be payable on that amount at a rate equal to the base lending rate for sterling of National Westminster Bank plc applicable from time to time plus three (3) percent compounded annually from the date when the payment is due until and including the date the payment is made;

6.6.2 the Party to whom the amount is due may terminate the Transaction in accordance with Clause 10.2;

6.6.3 the Party to whom the amount is due may, upon notice to the Party who has failed to pay, suspend the Transaction until such time as payment is received.

6.7 A Party shall be entitled to set off against any undisputed amounts which it is due to pay to the other Party in respect of any or all Transactions with such Party, any undisputed amounts that it is due to receive from such Party.

\section{7. $\quad$ Force Majeure}

7.1 If a Party is by reason of Force Majeure rendered unable wholly or in part to carry out its obligations in accordance with Clause 4, then upon notice in writing of such Force Majeure from the Party affected to the other Party as soon as reasonably practicable after the occurrence of the event or circumstances relied on, the Party affected shall be relieved of liability to the extent that it is in breach by reason of Force Majeure and for the period during which such Force Majeure persists, provided that:

7.1.1 the Party seeking relief under this Clause 7 shall advise the other Party as soon as practicable of the event or circumstance constituting Force Majeure together with its estimate of the likely effect of such Force Majeure on its ability to perform its obligations hereunder and of the likely period of such Force Majeure; and

7.1.2 the Party affected shall use all reasonable endeavours to terminate or overcome the event or circumstance constituting Force Majeure.

7.2 Either Party may terminate a Transaction by giving three (3) Banking Days notice to the other if Force Majeure in respect of that Transaction continues for seven (7) Days or more.

\section{Information and Confidentiality}

The terms and conditions of the Transaction and all information provided thereunder shall be treated as confidential and shall not be disclosed without the prior written consent of the other Party, save that consent shall not be required for disclosure

8.1 to directors, employees or Affiliates of either Party, provided that they in turn are required by that Party to treat the information disclosed as confidential;

to persons professionally engaged by either Party, provided that they in turn are required by that Party to treat the information disclosed as confidential; 
to any bank or other financial institution in relation to the financing of either Party's business activities, provided that the bank or other financial institution, as the case may be, is required by that Party to treat the information disclosed as confidential;

to the extent required by any applicable laws, judicial process or the rules and regulations of any recognised stock exchange;

to any intending assignee of the rights and interests of either Party under the Transaction provided that such intending assignee in turn is required by that Party to treat the information disclosed as confidential; 8 ; or

\section{Assignment}

9.1 Subject to Clause 9.2, neither Party shall assign to any person any of its rights or obligations in respect of a Transaction without the written consent of the other Party, which consent shall not be unreasonably withlield. For these purposes it shall be unreasonable to withhold consent in the case of an assignee that is demonstrably capable of fulfiling the obligations of the assignor in respect of a Transaction.

9.2 A Party may assign its rights and obligations in respect of a Transaction to an Affiliate on notice to, but withou the consent of the other Party provided that the assignor shall not be relieved of any obligations that such Affiliate fails to perform.

10 .

\section{Term and Termination}

The non-defaulting Party may terminate the Transaction forthwith by giving notice to the other Party:

10.1.1 in the event of the other Party becoming insolvent, ceasing to trade or having a receiver, liquidator, administrator or administrative receiver appointed over some or all of its assets or if proceedings are commenced for its dissolution or winding up (other than a voluntary winding up for the purposes of solvent amalgamation or reconstruction); or

10.1.2 in the event of the other Party being in breach of Clause 3; or

10.1.3 in the event of the other Party failing to provide or maintain security for performance of its financial obligations as agreed at the date of the Transaction; or

10.1.4 in the event of a material adverse change in the financial standing of the other Party when compared to such Party's financial standing as at the date of the Transaction which change affects its ability to perform its financial obligations in respect of the Transaction, and such Party fails to provide reasonable security for the performance of its financial obligations in respect of the Transaction within three (3) Banking Days of the other Party's request therefor.

The non-defaulting Party may terminate the Transaction by giving five (5) Banking Days' notice to the other Party in the event that other Party:

10.2.1 is materially in breach of any of its obligations under the Transaction;

10.2.2 fails to pay the amount specified in the Monthly Statement in accordance with Clause 6; provided that the Party in breach has failed to remedy the breach before expiry of the notice period. In the case of the breach being remedied, the notice is deemed not to have been given.

For the purpose of this Clause 10.2 a persistent failure by one Party to make Trade Nominations in respect of a Transaction shall be deemed to constitute a material breach.

10.3 The termination of the Transaction, however occurring, shall not affect any rights or obligations that may have accrued to either Party prior to termination.

10.4 Following termination in accordance with Clauses 10.1.1, 10.1.2 or 10.2, one Party shall pay to the other the Early Termination Payment within five (5) Banking Days of notification of the amount of the Early Termination Payment in accordance with Clauses $10.5,10.6$ and 10.7

10.5 The Early Temination Payment shall be the amount (if any) calculated by the non-defaulting party as follows:

(MV-RV)-1 where the non-defaulting party is the Buyer, or

(RV-MV)-I where the non-defaulting party is the Seller 
where:

(a) subject to Clause 10.6, "MV" is the market value of the Transaction calculated as follow:

$$
\text { sum of }(\mathrm{D} \times \mathrm{DQ}) \times \mathrm{GRP}
$$

where:

"D" is the number of Days from the date of temination to the end of the Supply Period on which the Parties had agreed in accordance with the Transaction to enter into NBP Trades;

"DQ" is the Daily Quantity for each D;

"GRP" is the Gas Reference Price, which is the average of the Pricing Indices published on the date of termination for each D.

(b) "RV" is the remaining contract value calculated as follows:

\section{$(\mathrm{D} \times \mathrm{DQ}) \times \mathrm{CP}$}

where:

"D" is the number of Days from the date of termination to the end of the Supply Period on which the Parties had agreed in accordance with the Transaction to enter into NBP Trades;

"DQ" is the Daily Quantity for each D

"CP" is the Contract Price;

(c) "I" is the amount by which the sum of MV-RV or RV-MV as applicable is discounted to reflect the present day value as at the termination date. The rate of interest for the purpose of this calculation shall be equal to LIBOR as quoted at the date of termination or the first Banking Day after the date of termination from the due date for payment of each future invoice and the deemed due date for payment of future invoices shall be the 20 th of each month.

Where none or only one of the Pricing Indices is available to calculate the Early Termination Payment, then the Early Termination Payment shall be calculated by taking the average of three reasoned quotations, such reasons to be reasonable, from three experts appointed by the non-defaulting Party.

11. Liabilities

Except as otherwise expressly provided herein, neither Party shall be liable to the other, whether in contract, tort or otherwise at law, for any loss of use, profits, contracts, production, revenue or for business interruption or for any consequential of indirect loss or damage of whatsoever nature and howsoever arising and even where caused by the negligence or breach of duty of either Party.

12. Waiver

No waiver by either Party of any breach by the other in respect of a Transaction shall operate or be construed as a warver of any other breach.

\section{Variation}

No variation to the provisions of a Transaction shall be valid unless it is in writing and signed by an authorised representative of each Party.

\section{Entirety}

On signature of the Confirmation by both Parties or deemed acceptance of the Confirmation in accordance with Clause 2.4 the Confirmation shall be the entire agreement between the Parties in relation to the Transaction and supersede and extinguish any representations previously given or made other than those included in these terms and conditions and the Confirmation.

\section{Severability}

If any of the provisions of the Transaction are found by a court or authority of competent jurisdiction to be void or unenforceable, such provision shall be deemed to be deleted from the Transaction and the remaining provisions shall continue in full force and effect. The Parties shall in such event seek to agree upon a valid and enforceable provision to replace the provision found to be void or unenforceable. 
Any norice or other communication to be given or made in respect of the Transaction by one Party to the other shall be given or made in writing to the other at that l'arty's registered office or such other address or contact number as that l'arty shal] notify to the other from time to time and shall be deemed to have been received:

16.1 if delivered by hand, on the Banking Day delivered or on the first Banking Day following the date of delivery if delivered on a day other than a Banking Day;

16.2 if sent by first class post, on the second Banking Day after the day of posting or, if sent from outside the United Kingdom, on the fifth Banking Day following the day of posting;

16.3 in the case of a facsimile transmission, on the day of transmission if that day is a Banking Day or on the first Banking Day after transmission if that day is not a Banking Day and provided that a valid transmission report confirming good receipt is generated.

Where a notice is sent by facsimile, the Party giving the notice shall (but without prejudice to Clause 16.3), if so requested by the other Party, resend the notice as soon as reasonably practicable by facsimile.

17. Applicable Law

The Transaction shall be governed by and construed in accordance with English Law and the Parties shall submit to the exclusive jurisdiction of the English Courts. 


\begin{tabular}{|c|c|c|}
\hline \multirow[b]{2}{*}{ SELLER } & & INSTRUCTIONS FOR USE \\
\hline & 1. & $\begin{array}{l}\text { Complete the Seller's details, name of the Buyer, Supply Period, Daily Quantity, Contract Price, method of } \\
\text { compensation and any special conditions. }\end{array}$ \\
\hline \multirow{5}{*}{ BUYER } & 2. & Sign the Confirmation. \\
\hline & 3. & Send the Confirmation to the Buyer by fax within 3 Banking Days of the transaction. \\
\hline & 1. & $\begin{array}{l}\text { On receipt of a Confirmation, check the details. If correct, sign and return to the Seller by fax within } 3 \\
\text { Banking Days of receipt of the Confirmation. Refer any inaccuracies to the Seller immediately. }\end{array}$ \\
\hline & 2. & $\begin{array}{l}\text { IF YOU DO NOT SIGN AND RETURN THE CONFIRMATION WITHIN THREE BANKING } \\
\text { DAYS OF RECEIPT, YOU WILL BE DEEMLD TO ACCEPT ITS TERMS }\end{array}$ \\
\hline & 3. & $\begin{array}{l}\text { If you do not receive a Confirmation within } 3 \text { Banking Days of the Transaction, complete the details and } \\
\text { send the Seller the Confirmation. }\end{array}$ \\
\hline
\end{tabular}

The SELLER and the BUYER named below hereby agree that this Confirmation confirms the details of an agreement to undertake NBP Trades in accordance with the Short Term Flat NBP Trading Terms and Conditions Ref. NBP 1997 and C6 of the Network Code.

SELLER:

(including AT LINK Reference)

BUYER:

(including AT LINK Reference) :

SUPPLY PERIOD:

DAILY QUANTITY:

CONTRACT PRICE:

COMPENSATION FOR BREACH WITHIN CLAUSES 4.2 OR 4.3:

SMP in accordance with option A

SAP or actual loss in accordance with option B

SPECIAL CONDITIONS:

Date and time of 'Transaction:

Signed Signed 


\section{Appendix C. Conversion values}

\section{Energy}

\section{British Thermal Units (Btu)}

$1 \mathrm{Btu}=1,055.05585262$ joules $(\mathrm{J})$

Million Btus (MMBtu)

$1 \mathrm{MMBtu}=1,055 \mathrm{MJ}$

Calorie (cal)

$1(\mathrm{cal})=4.1868 \mathrm{~J}$

Kilocalories (kcal)

$1000 \mathrm{kcal}=3,968 \mathrm{Btu}$

$1000 \mathrm{kcal}=1.163 \mathrm{kWh}$

$1000 \mathrm{kcal}=1$ thermie

Kilowatt (kW)

$1 \mathrm{~kW}=1000$ watts

$1 \mathrm{~kW}=1.340 \mathrm{hp}$

$1 \mathrm{~kW}=1.359 \mathrm{PS} / \mathrm{CV}$

$1 \mathrm{~kW}=737$ foot pounds/second

Kilowatt hours (kWh)

$1 \mathrm{kWh}=859.84 \mathrm{kcal}$

$1 \mathrm{kWh}=3.597$ megajoules $(\mathrm{MJ})$

$1 \mathrm{kWh}=3,412 \mathrm{Btu}$

*This conversion can range from 6.5 to 7.9 depending on the type of crude oil; the factor of 7.33 is the one commonly used for approximation.

Megajoules (MJ)
$1 \mathrm{MJ}=238.846 \mathrm{kcal}$
$1 \mathrm{MJ}=947.817 \mathrm{Btu}$
$1 \mathrm{MJ}=0.278 \mathrm{kWh}$
Therms $($ thm)
$1 \mathrm{thm}=25,200 \mathrm{kcal}$
$1 \mathrm{thm}=100,000 \mathrm{Btu}$
$1 \mathrm{thm}=29.3071 \mathrm{kWh}$
$1 \mathrm{thm}=25.2$ thermies
$1 \mathrm{Mthm}=2,520$ toe
Tonnes of oil equivalent (toe)
1 toe $=10,000,000 \mathrm{kcal}$
1 toe $=41.868 \mathrm{GJ}$
1 toe $=11,630 \mathrm{kWh}$
1 toe $=396.8254$ thms
1 toe $=39.6825 \mathrm{MMBtu}$
1 toe $=7.33$ boe

\section{Volume}

\author{
Cubic metre \\ $1 \mathrm{~m} 3=10001$ \\ $1 \mathrm{~m} 3=35.3147 \mathrm{cu} \mathrm{ft}$ \\ $1 \mathrm{~m} 3=6.28981077074 \mathrm{bbl}$ oil \\ Normal Cubic Metre gas (measured at 0deg \\ Celsius) \\ $1 \mathrm{Nm} 3=37.32614 \mathrm{cu} \mathrm{ft}$ \\ $1 \mathrm{Nm} 3=1.05697 \mathrm{Scm}$ \\ Standard Cubic Metre (measured at 15deg \\ Celsius) \\ $1 \mathrm{Scm}=35.31445 \mathrm{cu} \mathrm{ft}$ \\ $1 \mathrm{Scm}=0.9461 \mathrm{Nm} 3$ \\ Billion cubic metres \\ $1 \mathrm{bcm} \mathrm{NG}=725,000 \mathrm{t}$ LNG \\ Million tonnes LNG \\ $1 \mathrm{Mt} \mathrm{LNG}=1.3793 \mathrm{bcm} \mathrm{NG} *$ \\ $1 \mathrm{Mt} \mathrm{LNG}=1.379 \mathrm{Nbcm} \mathrm{NG}$ \\ $1 \mathrm{Mt} \mathrm{LNG}=1.457 .56 \mathrm{Sbcm} \mathrm{NG}$
}

*This conversion can range from 1.333 @ 0C to 1.460 @ 20C, depending on temperature chosen when calculating the cubic metres; the factor of 1.3793 is the one commonly used. 


\section{Energy/Volume equivalences}

$$
\begin{aligned}
& \text { Barrels of oil equivalent (boe) } \\
& 1 \text { boe }=160 \mathrm{~m} 3 \\
& \text { Cubic feet of Natural Gas (cu ft) } \\
& 1 \mathrm{cu} \mathrm{ft}=0.0001767 \text { boe } \\
& 1 \mathrm{cu} \mathrm{ft}=1,027 \mathrm{Btu} \\
& 1 \mathrm{scf}=1000 \mathrm{Btu} \\
& 1 \mathrm{MMscf}=172.3 \text { toe } \\
& \text { Cubic metre of Natural Gas (m3) } \\
& 1 \mathrm{~m} 3=0.36 \text { thm }
\end{aligned}
$$

Billion cubic metres per annum (bcma)

$1 \mathrm{bcma}=1.038704 \mathrm{Mtpd}$

\author{
Therm (thm) \\ $1 \mathrm{thm}=2.63764 \mathrm{Nm} 3$ \\ $1 \mathrm{thm}=2.78789 \mathrm{Scm}$ \\ Million therms (Mthm) \\ $1 \mathrm{Mthm}=2.78789 \mathrm{mcm}$ \\ Million therms per day (Mtpd) \\ $1 \mathrm{Mtpd}=0.96273824 \mathrm{bcma}$ \\ Tonnes LNG $(t)$ \\ $1 \mathrm{t} \mathrm{LNG}=52$ MMBtu \\ $1 \mathrm{t} \mathrm{LNG}=522.816520 \mathrm{thm}$ \\ $1 \mathrm{t} \mathrm{LNG}=1.24234$ toe \\ Tonnes of oil equivalent (toe) \\ 1 toe $\sim 1,125 \mathrm{cu} \mathrm{m}$
}

Sources for conversion values:

Energy Information Administration, Annual Energy Review 2008, Appendix B.

http://www.eia.doe.gov/emeu/aer/append_b.html

Chemlink Pty Ltd 'conversion factors relevant to petrochemical activities'

http://www.chemlink.com.au/conversions.htm

Icis-heren ESGM 'conversion factors' table

National Grid Gas Ten Year Statement 'conversion matrix'

BP Statistical review 'conversion factors'

http://www.bp.com/extendedsectiongenericarticle.do? categoryId=9023800\&contentId=7044894

Society of petroleum engineers 'unit conversion factors' tables

http://www.spe.org/spe-

app/basicSearchRD.do?selectedDatabaseNames=SPEWEB,SPEWEB_JPT,SPEWEB_MEETING

S,ConsDirDB,TSPRODDB,RPPRODDB\&search Text=energy \% 20conversions\&searchSelect=0

\section{Note:}

A simple to use on-line conversion provided by IUK Interconnector Ltd can be accessed at: http://www.interconnector.com/onlineservices/converter.htm 


\section{Appendix D. ICE UK NBP Natural Gas Futures Contract specification}

IICe $_{\text {FUTURES EUROPE* }}$

ICE UK Natural Gas Futures (Monthly)

Contract Specifications

\begin{tabular}{|c|c|}
\hline Description & $\begin{array}{l}\text { Contracts are for physical delivery through the transfer of } \\
\text { rights in respect of Natural Gas at the National Balancing } \\
\text { Point. Delivery is made equally each day throughout the } \\
\text { delivery period. }\end{array}$ \\
\hline Trading Period/Strip & $\begin{array}{l}16-18 \text { consecutive months, } 11-12 \text { quarters and } 9 \\
\text { seasons. Months, quarters and seasons are listed in } \\
\text { parallel. }\end{array}$ \\
\hline Expiration Date & $\begin{array}{l}\text { Trading shall cease at the close of business two business } \\
\text { days prior to the first calendar day of the delivery month, } \\
\text { quarter or season. }\end{array}$ \\
\hline Contract Security & $\begin{array}{l}\text { ICEU acts as central counterparty to all trades there by } \\
\text { guaranteeing the financial performance of ICE Futures } \\
\text { Europe contracts registered in the name of its Members up } \\
\text { to and including delivery, exercise and/or settlement. }\end{array}$ \\
\hline Trading Hours & 07:00 - 17:00, Local London Time (LLT), Monday - Friday. \\
\hline Contract Size & $\begin{array}{l}\text { Multiples of } 5 \text { lots of } 1,000 \text { therms per lot of natural gas } \\
\text { per day. }\end{array}$ \\
\hline Units of Trading & $\begin{array}{l}1 \text { lot equals } 1,000 \text { therms of natural gas per day ( } 1 \text { therm } \\
=29.3 \text { kilowatt hours) }\end{array}$ \\
\hline Quotation & The contract price is in Sterling and in pence per therm \\
\hline Minimum Price Flux & $\begin{array}{l}\text { Futures/Blocks }-0.01 \text { pence/therm } \\
\text { EFPs/EFSs }-0.005 \text { pence/therm }\end{array}$ \\
\hline Maximum Price Flux & There are no limits \\
\hline Settlement Prices & $\begin{array}{l}\text { The weighted average price of trades during a fifteen } \\
\text { minute settlement period from 16:00:00, London time. }\end{array}$ \\
\hline Daily Margin & All open contracts are marked-to-market daily. \\
\hline Position Limits & There are no position limits. \\
\hline
\end{tabular}


Contract Specifications

Trading Methods

Electronic futures, Exchange for physical (EFP), Exchange for swap (EFS) and Block Trades are available for this contract.

Delivery/Settlement Basis

Matching Acquiring and Disposing Trade Nominations

(buyer from ICEU, seller to ICEU) are input by buyer and seller to National Grid Transco via Gemini before 18:30 on

the business day prior to delivery. Delivery takes place in

kilowatt-hours (29.3071 kilowatt hours per therm).

Source: ICE website 


\section{Glossary}

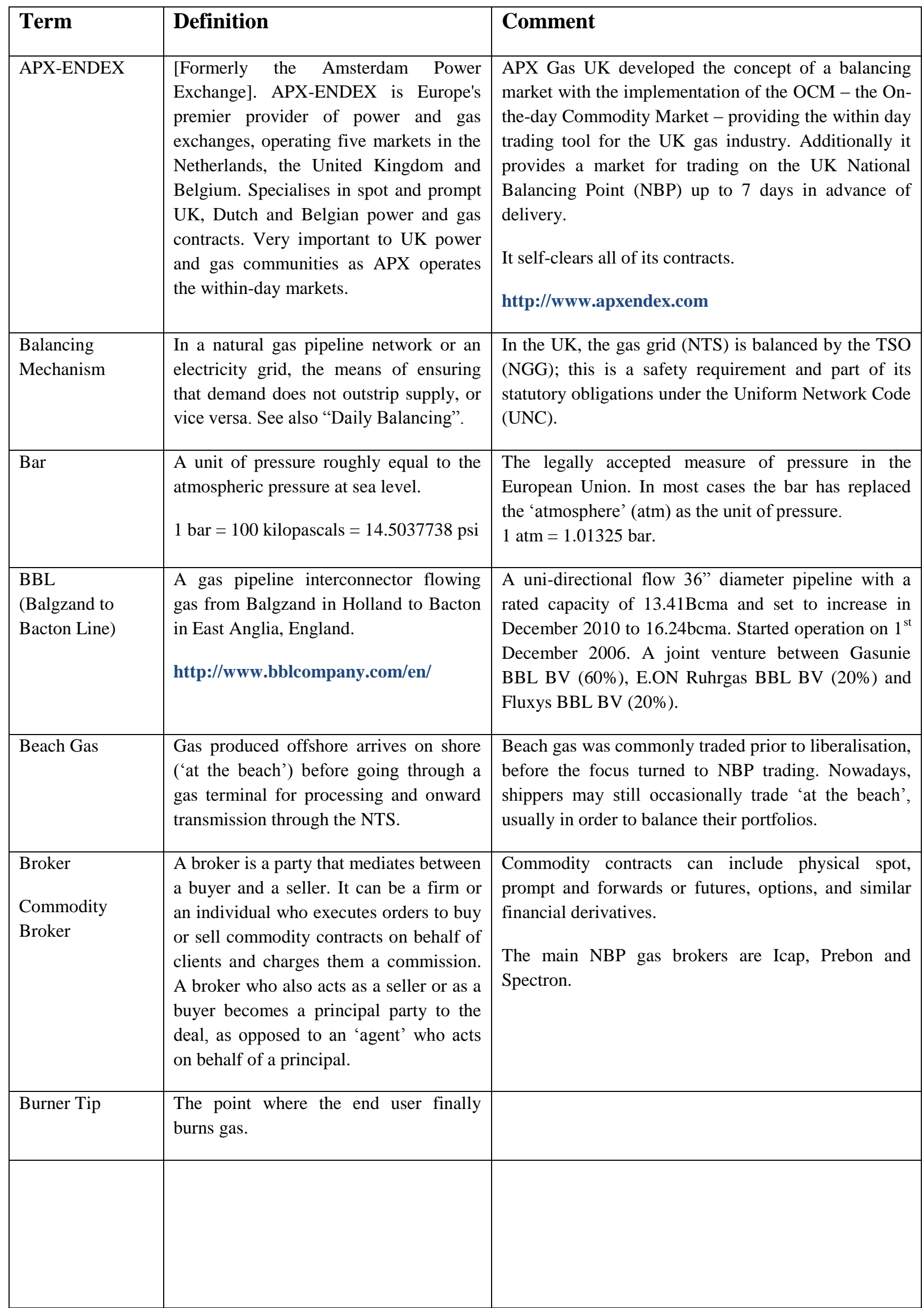




\begin{tabular}{|c|c|c|}
\hline $\begin{array}{l}\text { Calorific value } \\
(\mathrm{CV})\end{array}$ & $\begin{array}{l}\text { The CV refers to the amount of energy } \\
\text { released when a known volume of fuel is } \\
\text { completely combusted under specified } \\
\text { conditions. } \\
\text { By custom the basic calorific value for } \\
\text { solid and liquid fuels is the gross } \\
\text { calorific value at constant volume and } \\
\text { for gaseous fuels it is the gross calorific } \\
\text { value at constant pressure. The word } \\
\text { 'gross' here signifies that the water } \\
\text { formed and liberated during combustion } \\
\text { is in the liquid phase. The CV of solid } \\
\text { and liquid fuels is quoted in megajoules } \\
\text { per kilogramme }(\mathrm{MJ} / \mathrm{kg} \text { ) }\end{array}$ & $\begin{array}{l}\text { The CV of natural gas, which is dry, gross and } \\
\text { measured at standard conditions of temperature and } \\
\text { pressure, is usually quoted in megajoules per cubic } \\
\text { metre }(\mathrm{MJ} / \mathrm{m} 3) \text {. } \\
\text { Gas passing through the National Grid pipeline system } \\
\text { has a CV of } 37.5 \mathrm{MJ} / \mathrm{m} 3 \text { to } 43.0 \mathrm{MJ} / \mathrm{m} 3 \text {. } \\
\text { Typical CV figures of some fuels are: } \\
\text { - Wood: } 16 \\
\text { - Steam coal: } 36 \\
\text { - Methane (North Sea gas): } 39 \\
\text { - Petrol: } 44.8-46.9 \\
\text { - Propane: } 94 \\
\text { Butane: } 118\end{array}$ \\
\hline Capacity & $\begin{array}{l}\text { A measure of the amount of gas that a } \\
\text { pipeline is rated to transport. This will } \\
\text { usually be quoted as a flow rate. }\end{array}$ & \\
\hline $\begin{array}{l}\text { Capacity } \\
\text { Auctions }\end{array}$ & $\begin{array}{l}\text { The method employed by the UK TSO } \\
\text { (National Grid Gas) to sell capacity at } \\
\text { each of the system's Entry Points. It does } \\
\text { so in accordance with its obligations } \\
\text { under the Uniform Network Code. }\end{array}$ & $\begin{array}{l}\text { There are several types of System Entry Capacity } \\
\text { (SEC), with trading periods up to } 16 \text { years forward. } \\
\text { The three main categories are Quarterly (QSEC), } \\
\text { Annual Monthly (AMSEC) and Rolling Monthly } \\
\text { (RMSEC). } \\
\text { More information can be obtained at: } \\
\text { http://www.nationalgrid.com/uk/Gas/Data/CA/ }\end{array}$ \\
\hline Capacity Trading & $\begin{array}{l}\text { The trading between gas shippers of } \\
\text { 'space' within a pipeline system giving } \\
\text { the purchaser the right to transport gas } \\
\text { through that system. }\end{array}$ & $\begin{array}{l}\text { In the UK, capacity is initially bought from National } \\
\text { Grid Gas at one of the Entry Points to the NTS (see } \\
\text { "Capacity Auctions" above). Capacity can be re-traded } \\
\text { between shippers. }\end{array}$ \\
\hline Cash Settlement & $\begin{array}{l}\text { The financial settlement of futures } \\
\text { contracts, at expiry, by reference to an } \\
\text { Index (as opposed to actual physical } \\
\text { delivery). }\end{array}$ & $\begin{array}{l}\text { Although most commodity futures contracts are based } \\
\text { on physical delivery, there are some (such as the ICE } \\
\text { Brent contract) which allow for any open contracts at } \\
\text { expiry to be settled financially. }\end{array}$ \\
\hline $\begin{array}{l}\text { CCGT } \\
\text { (Combined Cycle } \\
\text { Gas Turbine) }\end{array}$ & $\begin{array}{l}\text { CCGT power generation is the most } \\
\text { energy efficient and clean method of } \\
\text { fossil fuel generation. Natural gas is } \\
\text { burnt in a combustion chamber from } \\
\text { where hot combustion gases expand } \\
\text { through the gas turbine, which drives } \\
\text { generators to produce electricity. The hot } \\
\text { exhaust gases contain recoverable energy } \\
\text { and are used in waste heat recovery } \\
\text { boilers to generate high-pressure steam } \\
\text { which is used to drive a steam turbine to } \\
\text { generate additional electricity. }\end{array}$ & $\begin{array}{l}\text { The size of a large scale CCGT power plant can vary } \\
\text { but a typical 'set' would be a } 400 \text { MW gas turbine } \\
\text { coupled to a } 200 \text { MW steam turbine giving } 600 \text { MW. } \\
\text { There could be } 2-6 \text { 'sets' forming a power station's } \\
\text { output. The high efficiency of CCGTs is reached by } \\
\text { combining both gas and steam cycles, whereby high } \\
\text { input temperatures and low output temperatures can be } \\
\text { achieved. The efficiency of the cycles add, because } \\
\text { they are powered by the same fuel source. The latest } \\
\text { CCGTs to be built, such as the } 860 \mathrm{MW} \text { plant at } \\
\text { Carrington near Manchester, are expected to operate at } \\
\text { efficiencies circa } 57 \% \text {. }\end{array}$ \\
\hline & & \\
\hline
\end{tabular}




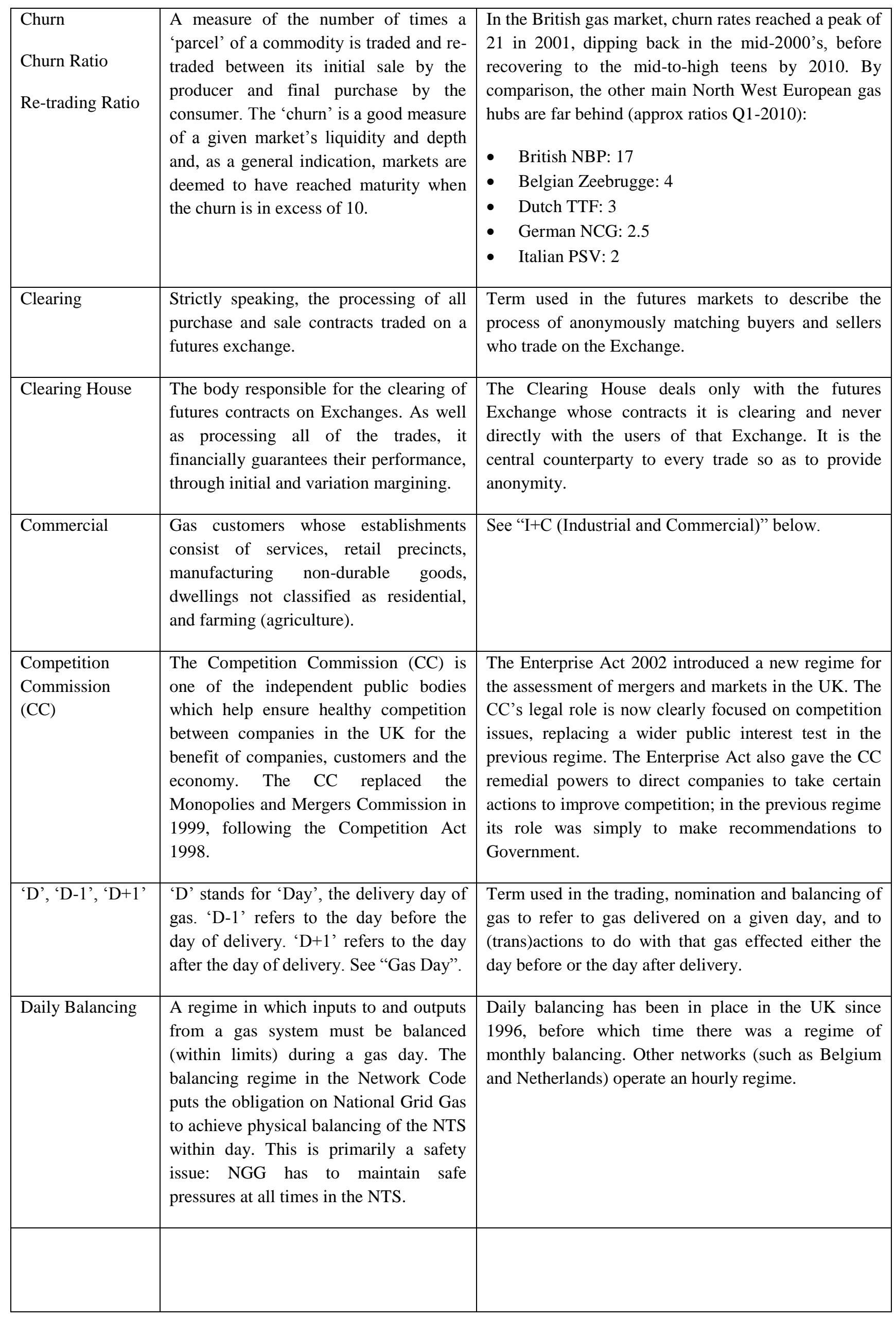




\begin{tabular}{|c|c|c|}
\hline $\begin{array}{l}\text { Daily Metered } \\
\text { Sites } \\
\text { (DMs) }\end{array}$ & $\begin{array}{l}\text { Supply points/sites with meters which } \\
\text { read gas volume either on a continuous } \\
\text { or on a daily basis for billing and } \\
\text { balancing. The sites are at large input } \\
\text { and offtake points on a gas system, } \\
\text { typically to the distribution networks and } \\
\text { to large industrial gas users. }\end{array}$ & \\
\hline Deliverability & $\begin{array}{l}\text { The rate at which gas can be supplied in } \\
\text { a given period, for instance from storage } \\
\text { or through a pipeline or distribution } \\
\text { network in a single } 24 \text {-hour period. }\end{array}$ & $\begin{array}{l}\text { Usually expressed as a flow rate and dependent on } \\
\text { factors such as the design and type of a storage facility } \\
\text { and the capacity of the pipeline network. }\end{array}$ \\
\hline Direct Connect & $\begin{array}{l}\text { One of the three main categories of gas } \\
\text { users defined as "large load' customers. } \\
\text { See also "I+C" and "Residential" }\end{array}$ & $\begin{array}{l}\text { These consist of power stations and large industrial } \\
\text { users such as cement works, steel works, glass works, } \\
\text { petrochemical plants, etc. }\end{array}$ \\
\hline $\begin{array}{l}\text { Distribution } \\
\text { Network (DN) } \\
\text { Distribution } \\
\text { Network operator } \\
\text { (DNO) }\end{array}$ & $\begin{array}{l}\text { Great Britain's } 12 \text { LDZs are now } \\
\text { grouped in to } 4 \text { Distribution Networks } \\
\text { (DNs), independently owned and } \\
\text { managed but all complying with the } \\
\text { Unified Network Code. }\end{array}$ & $\begin{array}{l}\text { The } 4 \text { Distribution Network Operators (DNOs) are: } \\
\text { National Grid, Scotia Gas Networks, Wales and West } \\
\text { Utilities, Northern Gas Networks. }\end{array}$ \\
\hline $\begin{array}{l}\text { EEX } \\
\text { (European } \\
\text { Energy } \\
\text { Exchange) }\end{array}$ & $\begin{array}{l}\text { The German energy exchange, providing } \\
\text { market platforms for trading in power, } \\
\text { natural gas, } \mathrm{CO}_{2} \text { emission allowances } \\
\text { and coal. }\end{array}$ & $\begin{array}{l}\text { EEX's main contracts are German Power and the } \\
\text { recent NCG gas futures contracts. It self-clears all of } \\
\text { its contracts. } \\
\text { http://www.eex.com }\end{array}$ \\
\hline $\begin{array}{l}\text { EFET } \\
\text { (European } \\
\text { Federation of } \\
\text { Energy Traders) }\end{array}$ & $\begin{array}{l}\text { Founded in 1999, EFET is a group of } \\
\text { more than } 90 \text { energy trading companies } \\
\text { from } 23 \text { European countries dedicated to } \\
\text { stimulate and promote energy trading } \\
\text { throughout Europe. EFET concentrates } \\
\text { its work on: Power, gas and emissions } \\
\text { market design; Energy policy and } \\
\text { regulation; Standard energy contracts; } \\
\text { Electronic transaction data standards. }\end{array}$ & $\begin{array}{l}\text { The EFET master contracts for wholesale OTC } \\
\text { transactions in gas, power and related products have } \\
\text { been a tremendous success right from the beginning. } \\
\text { They are well-accepted by the market and used as a } \\
\text { general reference point by traders conducting business } \\
\text { with counterparties throughout Europe. }\end{array}$ \\
\hline $\begin{array}{l}\text { EFP } \\
\text { (Exchange of } \\
\text { Futures for } \\
\text { Physical) }\end{array}$ & $\begin{array}{l}\text { The exchange of a specified quantity of a } \\
\text { cash commodity for an equivalent } \\
\text { quantity of futures, often done by two } \\
\text { traders having opposite hedged positions } \\
\text { that each wants to offset. Also called } \\
\text { exchange against actuals, exchange of } \\
\text { spot, exchange versus cash. }\end{array}$ & $\begin{array}{l}\text { It is important to note that when EFPs are registered } \\
\text { with the exchange, the volume is attributed to that } \\
\text { trading day but the price is not declared to the market } \\
\text { as this remains confidential between the two trading } \\
\text { parties. EFPs may be used to either initiate or liquidate } \\
\text { a futures position. }\end{array}$ \\
\hline End User & $\begin{array}{l}\text { All final customers of natural gas. } \\
\text { Includes: residential, commercial, light } \\
\text { industrial, heavy industrial customers } \\
\text { and direct connect users. }\end{array}$ & $\begin{array}{l}\text { Can also include: CHP generation, petrochemical } \\
\text { works, cement and glass manufacturers and CCGT } \\
\text { electricity generation plants. }\end{array}$ \\
\hline Entry Point & $\begin{array}{l}\text { The } 9 \text { locations where gas enters the } \\
\text { national gas transportation system } \\
\text { (NTS), also known as 'Terminals'. }\end{array}$ & $\begin{array}{l}\text { These are: Bacton, Barrow, Burton Point, Easington, } \\
\text { Isle of Grain, Milford Haven, Teesside, Theddlethorpe, } \\
\text { St Fergus. }\end{array}$ \\
\hline
\end{tabular}




\begin{tabular}{|c|c|c|}
\hline $\begin{array}{l}\text { EU Natural Gas } \\
\text { Directive }\end{array}$ & $\begin{array}{l}\text { The European Parliament and Council } \\
\text { Directive 98/30/EC concerning common } \\
\text { rules for the internal market in natural } \\
\text { gas. Its aim was to create a single } \\
\text { Europe-wide gas market by reducing } \\
\text { barriers to trade and encouraging new } \\
\text { entrants into the market. }\end{array}$ & $\begin{array}{l}\text { The full document can be accessed at: } \\
\text { http://eur- } \\
\text { lex.europa.eu/LexUriServ/LexUriServ.do?uri=CEL } \\
\text { EX:31998L0030:EN:HTML }\end{array}$ \\
\hline $\begin{array}{l}\text { Exit point } \\
\text { Off-take Point }\end{array}$ & $\begin{array}{l}\text { The locations where gas flows out of the } \\
\text { NTS and into the twelve Local } \\
\text { Distribution Zones or to Direct Connect } \\
\text { end users. }\end{array}$ & $\begin{array}{l}\text { There are currently over } 140 \text { such locations, which are } \\
\text { all daily metered. }\end{array}$ \\
\hline Flat Gas & $\begin{array}{l}\text { Gas traded and delivered at a constant } \\
\text { flow rate throughout the delivery period. }\end{array}$ & $\begin{array}{l}\text { Trading term used in the British 'NBP'97' contract in } \\
\text { which no interruption / volume tolerance is permitted. }\end{array}$ \\
\hline Firm Gas & $\begin{array}{l}\text { Gas sold on a continuous basis and } \\
\text { generally on long term contracts }\end{array}$ & \\
\hline $\begin{array}{l}\text { Force Majeure } \\
(\mathrm{FM})\end{array}$ & $\begin{array}{l}\text { Force Majeure literally means "greater } \\
\text { force". FM clauses in contracts excuse a } \\
\text { party from liability if some unforeseen } \\
\text { event beyond the control of that party } \\
\text { prevents it from performing its } \\
\text { obligations under the contract. }\end{array}$ & $\begin{array}{l}\text { Typically, Force Majeure clauses cover natural } \\
\text { disasters or other "Acts of God", war, or the failure of } \\
\text { third parties--such as suppliers and subcontractors--to } \\
\text { perform their obligations to the contracting party. It is } \\
\text { important to remember that FM clauses are intended to } \\
\text { excuse a party only if the failure to perform could not } \\
\text { be avoided by the exercise of due care by that party. }\end{array}$ \\
\hline Gas Day & $\begin{array}{l}\text { In the UK, the Gas Day runs from 06:00 } \\
\text { (through to 05:59 on the next calendar } \\
\text { day) }\end{array}$ & $\begin{array}{l}\text { This time was chosen as it falls at the end of the low } \\
\text { demand night period and before the beginning of the } \\
\text { morning peak. It also means that it is relatively easy to } \\
\text { balance the day's volumes (whether as shipper or as } \\
\text { TSO) during the quiet nighttime period. }\end{array}$ \\
\hline Gas Year & $\begin{array}{l}\text { In the UK, the Gas Year runs from 06:00 } \\
\text { on } 1^{\text {st }} \text { October (through to } 05: 59 \text { on } 30 \\
\text { September the following calendar year) }\end{array}$ & $\begin{array}{l}\text { Historically, the Gas Year was used as the time frame } \\
\text { for purchase contracts. October was chosen as the start } \\
\text { of the high demand winter season and the end of the } \\
\text { low demand summer season and off-shore } \\
\text { maintenance. Take or Pay obligations in Long Term } \\
\text { Contracts must be met by the end of a given Gas Year. }\end{array}$ \\
\hline Henry Hub & $\begin{array}{l}\text { The principal market hub for gas in the } \\
\text { US, located in Erath, Louisiana. It is at a } \\
\text { point on the US natural gas pipeline } \\
\text { system where nine interstate and four } \\
\text { intrastate pipelines interconnect. The } \\
\text { delivery point for the largest NYMEX } \\
\text { natural gas contract by volume. }\end{array}$ & $\begin{array}{l}\text { There are over } 30 \text { major market hubs in the U.S. but } \\
\text { the NYMEX Henry Hub gas futures contract has } \\
\text { become so successful, that Henry Hub has become the } \\
\text { benchmark for US gas pricing. Gas traded at any of the } \\
\text { other hubs is priced with reference to Henry Hub, } \\
\text { using a location differential which will vary according } \\
\text { to local supply and demand and to transportation costs. }\end{array}$ \\
\hline Hub & $\begin{array}{l}\text { A geographical location where multiple } \\
\text { participants trade services. }\end{array}$ & $\begin{array}{l}\text { The UK gas hub is 'NBP'; the major US gas hub is } \\
\text { 'Henry Hub'; in North West Europe, there are several } \\
\text { gas hubs e.g. Zeebrugge (Belgium), TTF (Holland), } \\
\text { NCG (Germany), PEGs (France), and others. }\end{array}$ \\
\hline & & \\
\hline
\end{tabular}




\begin{tabular}{|c|c|c|}
\hline $\begin{array}{l}\text { ICE } \\
\text { (InterContinental } \\
\text { Exchange) }\end{array}$ & $\begin{array}{l}\text { InterContinental Exchange is the world's } \\
\text { leading electronic marketplace for } \\
\text { energy trading and price discovery. ICE } \\
\text { Futures (formerly the International } \\
\text { Petroleum Exchange - IPE) operates the } \\
\text { leading electronic regulated futures and } \\
\text { options exchange for global energy } \\
\text { markets. ICE's robust trading platform } \\
\text { offers participants access to a wide } \\
\text { spectrum of energy futures products. } \\
\text { Contracts include the Brent global crude } \\
\text { benchmark contract, Gas Oil, Natural } \\
\text { Gas, Electricity, and ECX carbon } \\
\text { financial instruments. }\end{array}$ & $\begin{array}{l}\text { The ICE natural gas futures contract is based on } \\
\text { physical delivery of gas at the NBP and was launched } \\
\text { in January 1997. It quickly gained acceptance by } \\
\text { traders and the relative share of the NBP futures } \\
\text { contract to the overall traded volumes of gas at the } \\
\text { NBP has now reached in } 2010 \text { record levels of around } \\
30 \% \text {. The exchange publishes a Month Ahead index } \\
\text { which is commonly used to settle financial swaps and } \\
\text { in indexed physical contracts. } \\
\text { It self clears all of its contracts. } \\
\text { http://www.theice.com }\end{array}$ \\
\hline $\begin{array}{l}\mathrm{I}+\mathrm{C} \\
\text { (Industrial and } \\
\text { Commercial) }\end{array}$ & $\begin{array}{l}\text { One of the three main categories of gas } \\
\text { users - defined as 'medium load' } \\
\text { customers. }\end{array}$ & $\begin{array}{l}\text { See "Commercial", "Industrial", "Direct Connect" } \\
\text { and "Residential" }\end{array}$ \\
\hline Industrial & $\begin{array}{l}\text { Gas customers who are engaged } \\
\text { primarily in a process which creates or } \\
\text { changes raw unfinished materials into } \\
\text { another form or product. }\end{array}$ & See "I+C (Industrial and Commercial)". \\
\hline $\begin{array}{l}\text { Interconnector } 1 \\
\text { and } \\
\text { Interconnector } 2\end{array}$ & $\begin{array}{l}\text { Two gas pipelines flowing gas from } \\
\text { Moffat in Scotland to the Dublin area in } \\
\text { the Republic of Ireland. The sub-sea } \\
\text { sections run from Brighouse Bay in } \\
\text { Scotland to Gormanston (I/C1) and } \\
\text { Loughshinny (I/C2), both just north of } \\
\text { Dublin. }\end{array}$ & $\begin{array}{l}\text { These are both uni-directional flow pipelines, } \\
\text { Interconnector } 1 \text { being a } 24 \text { " line commissioned in } \\
1993 \text { and Interconnector } 2 \text { a } 30 \text { " line commissioned in } \\
2002 \text {. } \\
\text { They are both operated by BGE (UK) which is a } \\
\text { wholly owned subsidiary of Bord Gáis Éireann. }\end{array}$ \\
\hline $\begin{array}{l}\text { Interruptible } \\
\text { Capacity }\end{array}$ & $\begin{array}{l}\text { The variable capacity of a pipeline } \\
\text { system in excess of firm capacity. }\end{array}$ & $\begin{array}{l}\text { Interruptible (as-available) capacity may vary from } \\
\text { day to day depending on operating conditions, e.g., } \\
\text { loads, pressures, ambient temperatures, and the } \\
\text { availability of equipment, such as compressor units. }\end{array}$ \\
\hline $\begin{array}{l}\text { IUK } \\
\text { Interconnector }\end{array}$ & $\begin{array}{l}\text { A } 40 \text { " diameter gas pipeline flowing gas } \\
\text { to and from Zeebrugge in Belgium and } \\
\text { Bacton in East Anglia, England. It has a } \\
\text { rated capacity of } 20 \mathrm{Bcma} \text { in 'forward' } \\
\text { flow (GB to B) and } 25.5 \mathrm{Bcma} \text { in } \\
\text { 'reverse' flow' (B to GB). It was } \\
\text { commissioned in } 1998 \text {. }\end{array}$ & $\begin{array}{l}\text { It is a joint venture between Caisse de dépôt et } \\
\text { placement du Québec }(33.5 \%) \text {, Eni }(16.41 \%-5 \% \\
\text { directly and } 11.41 \% \text { through Distrigas), E.ON Ruhrgas } \\
(15.09 \%) \text {, ConocoPhillips }(10 \%) \text {, Gazprom }(10 \%) \text {, } \\
\text { Fluxys }(10 \%) \text {, GDF Suez (5\% - through Electrabel). }\end{array}$ \\
\hline $\begin{array}{l}\text { LCPD } \\
\text { (Large } \\
\text { Combustion Plant } \\
\text { Directive) }\end{array}$ & $\begin{array}{l}\text { Refers to 'Directive } 2001 / 80 / \mathrm{EC} \text { ' of the } \\
\text { European Parliament which aims to } \\
\text { reduce acidification, ground level ozone } \\
\text { and particle emissions throughout } \\
\text { Europe by controlling emissions of } \\
\text { sulphur dioxide, nitrogen oxides and dust } \\
\text { from large combustion plants in power } \\
\text { stations, petroleum refineries, steelworks } \\
\text { and other industrial processes running on } \\
\text { solid, liquid or gaseous fuel. }\end{array}$ & $\begin{array}{l}\text { All combustion plant built after } 1987 \text { must comply } \\
\text { with the emission limits as set out in the Directive; } \\
\text { those built before that date could choose to comply } \\
\text { (opt-in) with the limits or to 'opt-out'. Plant which } \\
\text { chose to opt-out of the Directive have had their } \\
\text { operation restricted, since } 1^{\text {st }} \text { January } 2008 \text {, to a } \\
\text { maximum of } 20,000 \text { hours or in any event must shut } \\
\text { down by } 31^{\text {st }} \text { December } 2015 \text {. } \\
\text { The full document can be accessed at: http://eur- } \\
\text { lex.europa.eu/LexUriServ/site/en/oj/2001/1_309/1_30 } \\
\text { 920011127en00010021.pdf }\end{array}$ \\
\hline
\end{tabular}




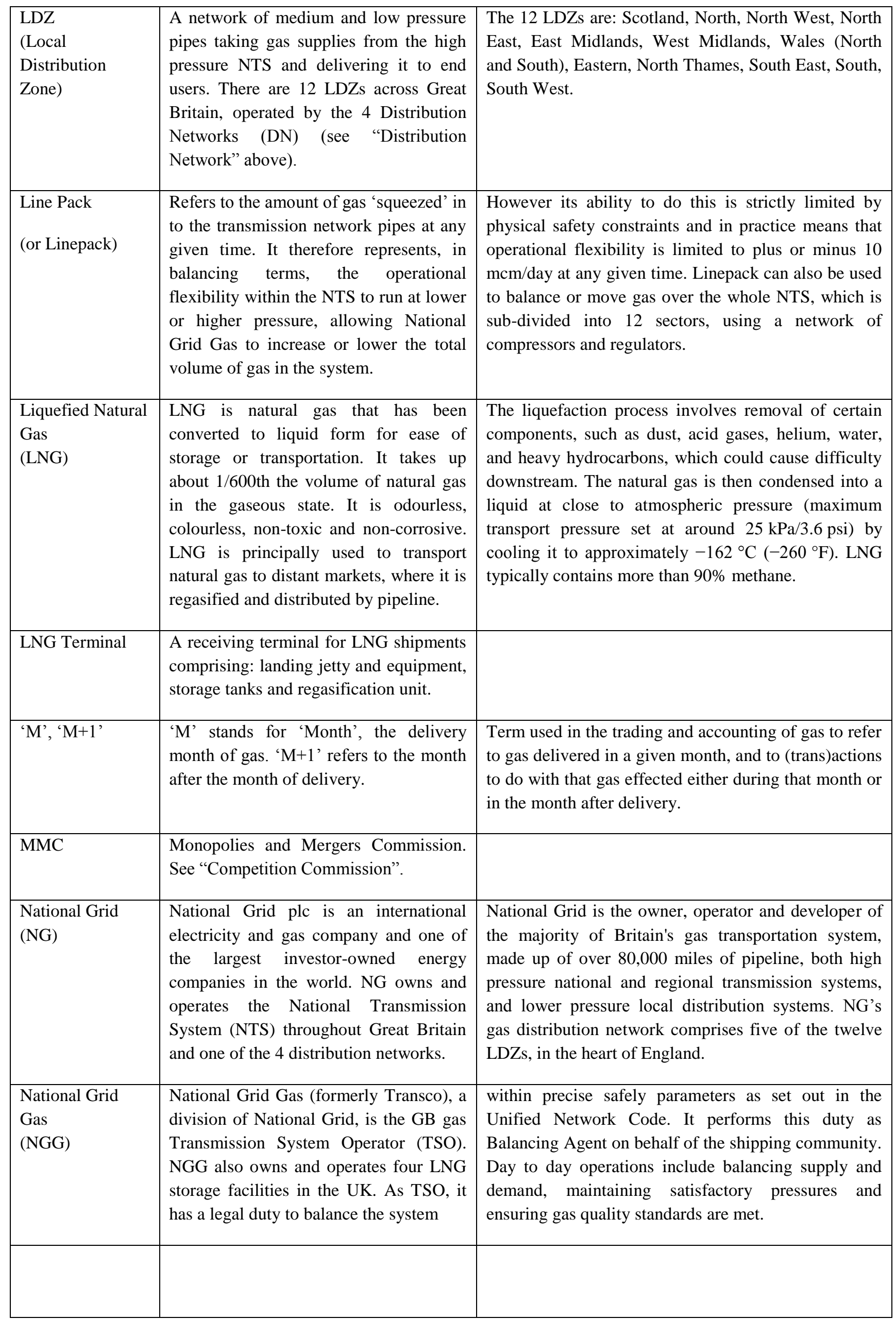




\begin{tabular}{|c|c|c|}
\hline $\begin{array}{l}\text { NBP } \\
\text { (National } \\
\text { Balancing Point) }\end{array}$ & $\begin{array}{l}\text { The National Balancing Point (NBP) is a } \\
\text { virtual point or location created by the } \\
\text { Network Code in order to promote the } \\
\text { balancing mechanism detailed in the } \\
\text { Code. In effect, it is the whole NTS. }\end{array}$ & $\begin{array}{l}\text { It is where shippers nominate their buys and sells and } \\
\text { where National Grid Gas balances the system on a } \\
\text { daily basis. The NBP also rapidly evolved as a trading } \\
\text { point and is the UK gas hub. Also forms the basis of } \\
\text { the ICE futures contract. }\end{array}$ \\
\hline NBP'97 & $\begin{array}{l}\text { Common name denoting the "Short } \\
\text { Term Flat NBP Trading Terms \& } \\
\text { Conditions - 1997", the standardised } \\
\text { contract used in Britain for trading gas at } \\
\text { the NBP. } \\
\text { As well as standardised billing and } \\
\text { payment terms, the contract has three } \\
\text { very important features that enabled } \\
\text { trading to develop successfully. }\end{array}$ & $\begin{array}{l}\text { The three main features are: } \\
\text { - Participants are 'kept whole', volumes delivered } \\
\text { are guaranteed and always equal to volumes } \\
\text { traded; } \\
\text { - Quantities traded are 'flat', volumes traded are } \\
\text { delivered at a constant flow rate throughout the } \\
\text { delivery period; } \\
\text { There is very limited 'Force Majeure': the only } \\
\text { relief from the obligation to deliver or take gas } \\
\text { from the NTS is an event beyond the control of } \\
\text { the affected party to make a nomination. }\end{array}$ \\
\hline $\begin{array}{l}\text { NCG } \\
\text { (NetConnect } \\
\text { Germany) }\end{array}$ & $\begin{array}{l}\text { Similar to NBP and will gradually get } \\
\text { larger as the 'virtual' one-zone delivery } \\
\text { area expands across the country. }\end{array}$ & $\begin{array}{l}\text { Designation of the natural gas futures contracts offered } \\
\text { on the EEX electronic exchange. } \\
\text { See "EEX". }\end{array}$ \\
\hline Network Code & $\begin{array}{l}\text { The document that set out the rules and } \\
\text { procedures for third party access to the } \\
\text { British pipeline grid and introduced the } \\
\text { regime of daily balancing. Its authority } \\
\text { was enshrined in the Gas Act (1995). } \\
\text { First came into effect in March } 1996 . \\
\text { Since revised, amended and updated and } \\
\text { replaced in } 2005 \text { by the Uniform } \\
\text { Network Code. }\end{array}$ & $\begin{array}{l}\text { BG plc was obliged, under the conditions of the BG } \\
\text { Licence (as determined by the Secretary of State } \\
\text { pursuant to section } 8(2) \text { of the Gas Act } 1995[2]) \text {, to } \\
\text { prepare a code governing the conveyance and storage } \\
\text { of gas. } \\
\text { See also "Uniform Network Code". }\end{array}$ \\
\hline Nominations & $\begin{array}{l}\text { Nominations are used to notify National } \\
\text { Grid Gas of expected gas flows and to } \\
\text { seal a trade under NBP'97 terms. The } \\
\text { nominations procedure is conducted } \\
\text { through 'Gemini': a dedicated computer } \\
\text { system for trade nominations. }\end{array}$ & $\begin{array}{l}\text { Three main categories are used by shippers: } \\
\text { - into the NBP on an entry service, specifying the } \\
\text { entry point, date and quantity; } \\
\text { from the NBP on an exit service specifying the } \\
\text { Daily Metered Site or exit point, date and } \\
\text { quantity; } \\
\text { from NBP to NBP, for gas trading, specifying the } \\
\text { date and quantity. }\end{array}$ \\
\hline $\begin{array}{l}\text { Non-Daily } \\
\text { Metered Sites } \\
\text { (NDMs) }\end{array}$ & $\begin{array}{l}\text { Supply points/sites with meters which } \\
\text { read gas volume at longer intervals than } \\
\text { daily. The sites are typically for small } \\
\text { I+C and residential gas users. }\end{array}$ & $\begin{array}{l}\text { A key change brought about in the UNC was the } \\
\text { obligation placed on Distribution Network Operators } \\
\text { (DNOs) to pass on to National Grid Gas their LDZ } \\
\text { stock information, or any other relevant data in this } \\
\text { respect, for the purpose of enabling NGG to carry out } \\
\text { its system balancing activities. }\end{array}$ \\
\hline $\begin{array}{l}\text { NTS } \\
\text { (National } \\
\text { Transmission } \\
\text { System) }\end{array}$ & $\begin{array}{l}\text { The NTS is the high pressure part of } \\
\text { National Grid's gas transmission system } \\
\text { and comprises over } 6,600 \mathrm{~km} \text { of high } \\
\text { pressure pipeline operating at } 45-85 \mathrm{bar}\end{array}$ & $\begin{array}{l}\text { The NTS forms the 'backbone' of gas transportation in } \\
\text { Great Britain and provides the 'virtual location' for } \\
\text { NBP trading; all gas within the NTS is said to be 'at } \\
\text { the NBP'. Gas travels through the network at an } \\
\text { average speed of } 25 \text { miles/hour. }\end{array}$ \\
\hline
\end{tabular}




\begin{tabular}{|c|c|c|}
\hline $\begin{array}{l}\text { OCM } \\
\text { (On-the-day } \\
\text { Commodity } \\
\text { Market) }\end{array}$ & $\begin{array}{l}\text { Successor to the Flexibility Mechanism } \\
\text { as set out in the Network Code to assist } \\
\text { the TSO to balance the NTS daily. } \\
\text { Introduced in 1999, it is a screen based } \\
\text { trading system operated by APX-Endex. }\end{array}$ & $\begin{array}{l}\text { Trades can be carried out from } 12 \text { noon on D-1 up to } \\
\text { 15:35 on D by Shippers or the TSO; after that time, the } \\
\text { TSO will always be on one side of every trade in its } \\
\text { role as balancing agent. Trading ceases at } 4 \text { am on D. }\end{array}$ \\
\hline OFFER & Office of Electricity Regulation & $\begin{array}{l}\text { The first regulator of the newly liberalised electricity } \\
\text { market. Merged with OFGAS in } 1999 \text { to form } \\
\text { OFGEM. }\end{array}$ \\
\hline Off-take Point & See "Exit Point" above. & \\
\hline OFGAS & Office of Gas Supply & $\begin{array}{l}\text { The first regulator of the newly liberalised gas market. } \\
\text { Merged with OFFER in } 1999 \text { to form OFGEM. }\end{array}$ \\
\hline $\begin{array}{l}\text { OFGEM } \\
\text { (Office of the Gas } \\
\text { and Electricity } \\
\text { Markets) }\end{array}$ & $\begin{array}{l}\text { Formed in } 1999 \text { by the merger of } \\
\text { OFGAS and OFGEM. Governed by an } \\
\text { independent Authority whose powers are } \\
\text { provided under the Gas Act 1986, the } \\
\text { Electricity Act 1989, the Utilities Act } \\
\text { 2000, the Competition Act } 1998 \text { and the } \\
\text { Enterprise Act 2000. OFGEM is funded } \\
\text { by collecting an annual licence fee from } \\
\text { the licensed companies they regulate but } \\
\text { is totally independent from them. }\end{array}$ & $\begin{array}{l}\text { OFGEM's aims are to: } \\
\text { - protect consumers by promoting competition; } \\
\text { - regulate the monopoly companies which run the } \\
\text { gas and electricity networks; } \\
\text { - help to secure Britain's energy supplies by } \\
\text { promoting competitive gas and electricity markets } \\
\text { - and regulating them so that there is adequate } \\
\text { investment in the networks; } \\
\text { - contribute to the drive to curb climate change. }\end{array}$ \\
\hline $\begin{array}{l}\text { OFT } \\
\text { (Office of Fair } \\
\text { Trading) }\end{array}$ & $\begin{array}{l}\text { The OFT is the UK's consumer and } \\
\text { competition authority, a non-ministerial } \\
\text { government department, established by } \\
\text { the Fair Trading Act } 1973 \text {. Its role was } \\
\text { modified and its powers changed with } \\
\text { the Enterprise Act } 2002 \text {. }\end{array}$ & $\begin{array}{l}\text { The majority of the OFT's work consists of analysing } \\
\text { markets, enforcing consumer and competition law, } \\
\text { merger control, licensing and supervisory work (of } \\
\text { consumer credit, estate agency, anti-money laundering } \\
\text { supervision), advocacy, delivering information, } \\
\text { education programmes and campaigns to business and } \\
\text { consumers. }\end{array}$ \\
\hline $\begin{array}{l}\text { Pipeline Quality } \\
\text { Gas }\end{array}$ & $\begin{array}{l}\text { Refers to the specific quality of gas to be } \\
\text { transported in a pipeline system, as } \\
\text { determined by the system operator. } \\
\text { Specifications vary between networks. } \\
\text { In Great Britain, the specification of the } \\
\text { gas that can be entered into the NTS is } \\
\text { governed by the Gas Safety } \\
\text { (Management) Regulations } 1996 \\
\text { [GS(M)R 1996], the full version of } \\
\text { which can be accessed at: } \\
\text { http://www.opsi.gov.uk/si/si1996/Uksi_ } \\
\text { 19960551_en_5.htm\#sdiv3 }\end{array}$ & $\begin{array}{l}\text { Natural gas, as it exists underground, is not exactly the } \\
\text { same as the natural gas that comes through the } \\
\text { pipelines to our homes and businesses. Natural gas } \\
\text { transported through pipelines must meet defined purity } \\
\text { specifications. The } 3 \text { main groups of parameters are: } \\
\text { - Energy content: Gross Calorific Value (GCV). } \\
\text { - Combustion properties: Wobbe Index, Soot } \\
\text { Index, Incomplete Combustion Factor, Hydrogen. } \\
\text { - Additional components: Total Sulphur, } \\
\text { Hydrogen Sulphide, Mercaptans (odourisers), } \\
\text { Hydrocarbon and Water Dewpoints, Oxygen, } \\
\text { CO2, Impurities, Temperature. }\end{array}$ \\
\hline $\begin{array}{l}\text { Regasification } \\
\text { Terminal }\end{array}$ & $\begin{array}{l}\text { Where LNG vessels are received and } \\
\text { their shipment transferred to holding } \\
\text { tanks before being reheated and } \\
\text { reconverted into pipeline gas. }\end{array}$ & $\begin{array}{l}\text { Usually connected to a storage and pipeline } \\
\text { distribution network to distribute natural gas to local } \\
\text { distribution companies. In some cases they may } \\
\text { directly feed a power station or industrial plant. }\end{array}$ \\
\hline Residential & $\begin{array}{l}\text { One of the three main categories of gas } \\
\text { users defined as 'small load' customers. }\end{array}$ & See also "I+C" and "Direct Connect". \\
\hline
\end{tabular}




\begin{tabular}{|c|c|c|}
\hline $\begin{array}{l}\text { Shipper } \\
\text { Gas Shipper } \\
\text { Shipper's Licence }\end{array}$ & $\begin{array}{l}\text { One of three categories of Licences set } \\
\text { out in the Gas Act (1995), alongside } \\
\text { Transporters (operators of the } \\
\text { distribution pipelines) and Suppliers } \\
\text { (selling gas to the end users). The } \\
\text { Shippers are in effect the 'wholesalers' } \\
\text { of gas, buying from producers and } \\
\text { selling to the Suppliers. }\end{array}$ & $\begin{array}{l}\text { Shipper's Licences are granted by OFGEM after due } \\
\text { consideration and examination of a proposed licence } \\
\text { holder's commercial intentions and financial standing. } \\
\text { In extremis, the Licence can be withdrawn if the } \\
\text { Shipper does not comply with the rules as laid down in } \\
\text { the Gas Act, the Unified Network Code and in the } \\
\text { OFGEM licence application. }\end{array}$ \\
\hline $\begin{array}{l}\text { SNIP } \\
\text { (Scotland to } \\
\text { Northern Ireland } \\
\text { natural gas } \\
\text { Pipeline) }\end{array}$ & $\begin{array}{l}\text { A gas pipeline interconnector flowing } \\
\text { gas from from Twynholm in Scotland } \\
\text { (where it ties in to the BGE } \\
\text { Interconnector to Eire) to Ballylumford } \\
\text { in Northern Ireland. }\end{array}$ & $\begin{array}{l}\text { This is a uni-directional flow 24" diameter pipeline, } \\
\text { commissioned in 1996. Premier Transmission Limited } \\
\text { (PTL) is the owner and operator. It transports gas to } \\
\text { Ballylumford Power Station which generates over half } \\
\text { of Northern Ireland's electricity needs and feeds the } \\
\text { Greater Belfast natural gas distribution system via the } \\
\text { Belfast Gas Transmission Pipeline. }\end{array}$ \\
\hline Storage & $\begin{array}{l}\text { Simply, a means of maintaining a reserve } \\
\text { of natural gas to allow supply to match } \\
\text { demand, either on a seasonal level or } \\
\text { from day to day, to within day. Stored } \\
\text { gas helps protect downstream markets, to } \\
\text { balance the system and to prevent supply } \\
\text { interruptions. The main types of gas } \\
\text { storage in the UK are: depleted fields, } \\
\text { salt caverns, LNG tankage, peak shaving } \\
\text { and linepack. }\end{array}$ & $\begin{array}{l}\text { The characteristics of the various types of gas storage } \\
\text { are: } \\
\text { - Depleted fields: High working volume/high } \\
\text { injection/low withdrawal } \\
\text { - Salt caverns: Low working volume/quite high } \\
\text { injection/very high withdrawal } \\
\text { - Peak Shaving: Low working volume/ low } \\
\text { injection/very high withdrawal }\end{array}$ \\
\hline Storage Injection & $\begin{array}{l}\text { The injection rate is the volume of gas } \\
\text { that can be put in to storage over a given } \\
\text { period and is dependent on the physical } \\
\text { attributes of each type of storage. }\end{array}$ & $\begin{array}{l}\text { Geological storage is most flexible: it can cope with } \\
\text { maximum injection rates from just } 10 \% \text { full to } 80-90 \% \\
\text { full. }\end{array}$ \\
\hline $\begin{array}{l}\text { Swing } \\
\end{array}$ & $\begin{array}{l}\text { A provision common in Long Term Gas } \\
\text { Contracts, under which a buyer has the } \\
\text { option to vary his demand, in a specified } \\
\text { band above or below average contract } \\
\text { quantity. }\end{array}$ & $\begin{array}{l}\text { This is an important feature of the 'old style' Long } \\
\text { Term Contracts as it provides the buyer with flexibility } \\
\text { at no extra cost. }\end{array}$ \\
\hline $\begin{array}{l}\text { System Average } \\
\text { Price } \\
\text { (SAP) }\end{array}$ & $\begin{array}{l}\text { The volume-weighted average price of } \\
\text { all trades conducted on the OCM for } \\
\text { delivery on a given Gas Day. }\end{array}$ & \\
\hline $\begin{array}{l}\text { System Marginal } \\
\text { price } \\
\text { (SMP) }\end{array}$ & $\begin{array}{l}\text { The highest and the lowest prices traded } \\
\text { on the OCM for a given Gas Day } \\
\text { become respectively the marginal selling } \\
\text { price (SMPs) and the marginal buying } \\
\text { price (SMPb). }\end{array}$ & $\begin{array}{l}\text { SMPs and SMPb are used to cash out shippers who are } \\
\text { out of balance on a given Gas Day where: Shippers } \\
\text { who are short of gas are cashed out at the highest } \\
\text { price, SMPs; Shippers who are long of gas are cashed } \\
\text { out at the lowest price, SMPb }\end{array}$ \\
\hline $\begin{array}{l}\text { Take or Pay } \\
\text { (TOP) }\end{array}$ & $\begin{array}{l}\text { A provision common in Long Term Gas } \\
\text { Contracts, under which a buyer agrees to } \\
\text { purchase and take delivery of a set } \\
\text { amount of gas in a given time period } \\
\text { (usually a Gas Year), or pay for an equal } \\
\text { or lesser quantity of gas regardless of } \\
\text { whether delivery is taken. }\end{array}$ & \\
\hline
\end{tabular}




\begin{tabular}{|c|c|c|}
\hline $\begin{array}{l}\text { Third Party } \\
\text { Access } \\
\text { (TPA) }\end{array}$ & $\begin{array}{l}\text { Open and non-discriminatory access to } \\
\text { networks by those who do not own the } \\
\text { physical network infrastructure. } \\
\text { Fundamental in facilitating greater } \\
\text { competition and making energy markets } \\
\text { work effectively. }\end{array}$ & $\begin{array}{l}\text { Under EU legislation, owners of interconnectors, } \\
\text { storage facilities and LNG import terminals may apply } \\
\text { for an exemption from the requirement to offer access } \\
\text { to third parties. Exemption is intended to promote the } \\
\text { development of such facilities in a competitive market } \\
\text { (such as in GB) where it is not necessary for the } \\
\text { facilities to be stringently regulated (for example, } \\
\text { tariffs would not need to be agreed by the regulator). }\end{array}$ \\
\hline $\begin{array}{l}\text { TSO } \\
\text { (Transmission } \\
\text { System Operator) }\end{array}$ & $\begin{array}{l}\text { The company responsible for the gas } \\
\text { pipeline system and its safe operation. }\end{array}$ & In Great Britain, the gas TSO is NGG (see above). \\
\hline $\begin{array}{l}\text { TTF } \\
\text { (Title Transfer } \\
\text { Facility) }\end{array}$ & $\begin{array}{l}\text { The Dutch gas trading hub, TTF, is a } \\
\text { virtual market place where the Dutch } \\
\text { TSO, Gas Trading Services (GTS), offers } \\
\text { market participants the opportunity to } \\
\text { transfer gas that is already present in the } \\
\text { GTS system ('entry-paid gas') to another } \\
\text { party. Can also be traded as futures } \\
\text { contracts on APX-Endex and on ICE. }\end{array}$ & $\begin{array}{l}\text { TTF can serve as a virtual entry point in the portfolio } \\
\text { of a shipper or trader who buys gas on TTF, or as a } \\
\text { virtual exit point in the portfolio of a shipper or trader } \\
\text { who sells gas on TTF. GTS registers the title transfers } \\
\text { of gas via TTF by means of a 'nomination'. This is an } \\
\text { electronic message stating the volumes of gas } \\
\text { transferred, and the purchasing and selling parties. }\end{array}$ \\
\hline $\begin{array}{l}\text { Uniform Network } \\
\text { Code } \\
\text { (UNC) }\end{array}$ & $\begin{array}{l}\text { The Uniform Network Code replaced the } \\
\text { Network Code in } 2005 \text { with a number of } \\
\text { amendments and updates to reflect the } \\
\text { experience gained from the first ten years } \\
\text { of the liberalised market. See also } \\
\text { "Network Code" above. }\end{array}$ & $\begin{array}{l}\text { The UNC added more clarity and detail in order to } \\
\text { enable shippers and the system operator to balance } \\
\text { more effectively. } \\
\text { The full document can be accessed at: } \\
\text { http://www.gasgovernance.co.uk/UNC }\end{array}$ \\
\hline WACOG & The Weighted Average Cost Of Gas & \\
\hline $\begin{array}{l}\text { Wobbe Index or } \\
\text { Wobbe Number }\end{array}$ & $\begin{array}{l}\text { This is the single most useful measure of } \\
\text { how a gas will burn. The Wobbe Index is } \\
\text { a calculated number - the calorific value } \\
\text { of the gas divided by the square root of } \\
\text { the relative density. The relative density } \\
\text { of a gas will determine how quickly a } \\
\text { gas will flow through a burner. The CV } \\
\text { and RD combined therefore represent a } \\
\text { measure of how quickly energy is } \\
\text { delivered to the burner. }\end{array}$ & $\begin{array}{l}\text { In Great Britain, the Wobbe Index of gas delivered to } \\
\text { the NTS is governed by the Gas Safety (Management) } \\
\text { Regulations } 1996 \text {, which stipulates: } \\
\text { WN range: } 47.20-51.41 \mathrm{MJ} / \mathrm{m} 3 \\
\text { See "Pipeline Quality Gas" above. }\end{array}$ \\
\hline Zeebrugge & $\begin{array}{l}\text { A Belgian port and the generic term used } \\
\text { for the market hub of the same name. } \\
\text { The Zeebrugge Hub is a so-called } \\
\text { physical hub, with natural gas made } \\
\text { available from neighbouring countries, } \\
\text { the nearby LNG terminal or the Belgian } \\
\text { market. Connecting to a variety of pipe } \\
\text { gas and LNG sources, the Zeebrugge } \\
\text { area has an overall throughput capacity } \\
\text { of about } 48 \mathrm{Bcma} \text {. }\end{array}$ & $\begin{array}{l}\text { The Zeebrugge area is considered to be one of the } \\
\text { most important natural gas landing points in the EU27. } \\
\text { The Interconnector Zeebrugge Terminal (IZT) } \\
\text { connects the Belgian grid (operated by Fluxys) to the } \\
\text { underwater Interconnector pipeline which runs to } \\
\text { Bacton in England. Gassco's Zeepipe Terminal (ZPT) } \\
\text { connects Norway's Troll and Sleipner offshore gas } \\
\text { fields to the Fluxys grid via the underwater Zeepipe } \\
\text { pipeline. The Zeebrugge LNG Terminal serves as a } \\
\text { gateway to supply LNG into North West Europe. }\end{array}$ \\
\hline
\end{tabular}

